

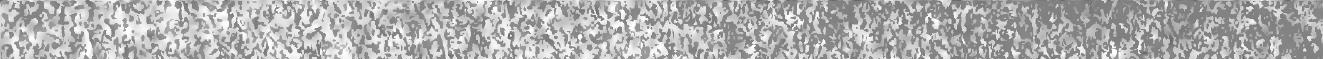
3)

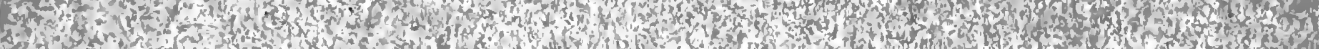

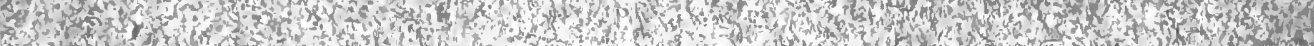

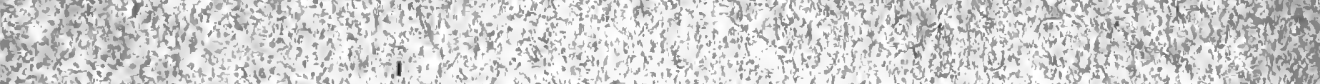
8.75

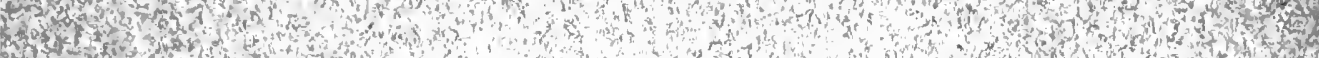

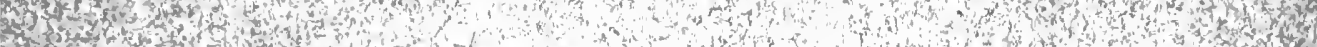

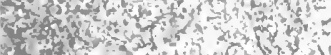
thisent
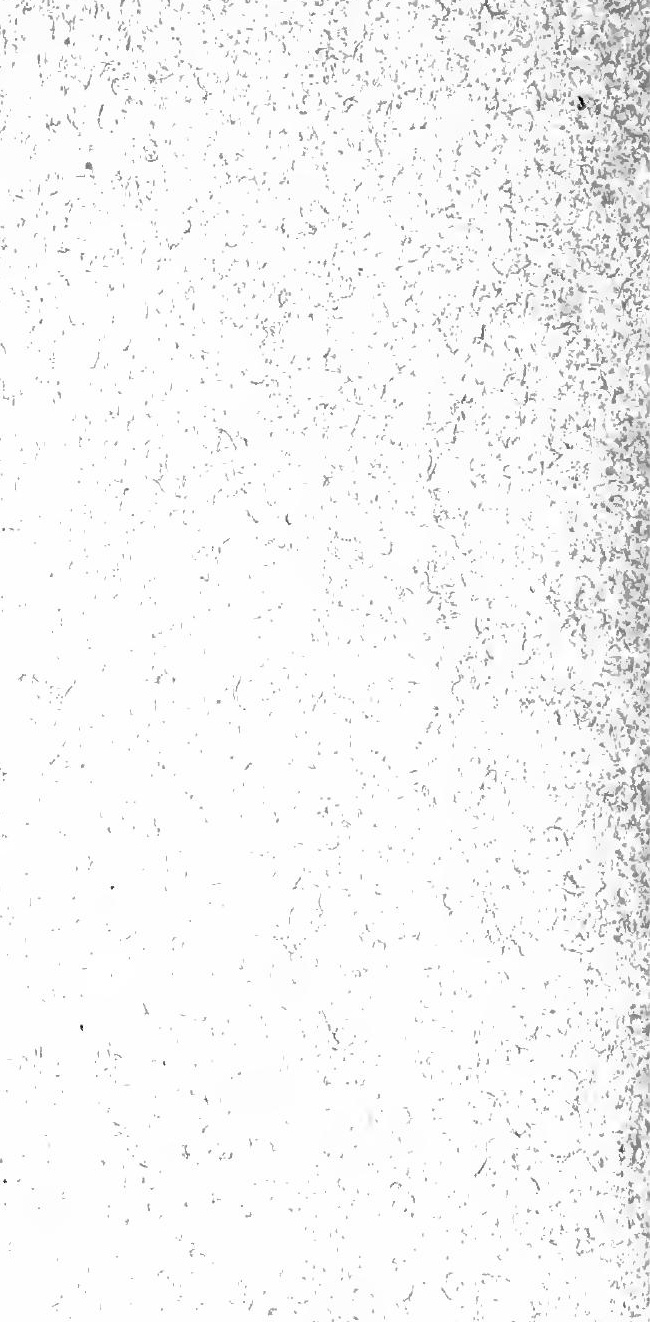
U. S. DEPARTMENT OF AGRICULTURE, BUREAU OF ANIMAL INDUSTRY.-BULLETIN 161.

A. D. Melvin, Chief of Bureat.

\section{A STUDY OF THE BACTERIA WHICH SURVIVE PASTEURIZATION.}

BY

S. HENRY AYERS,

Bacteriologist,

AND

WILLIAM T. JOHNSON, JR.,

Scientific Assistant, Dairy Dirision.

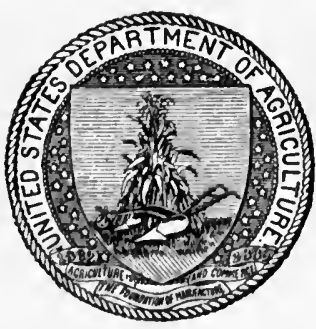

WASHINGTON

GOVERNMENT PRINTING OFFICE.

1913. 


\section{THE BUREAU OF ANIMAL INDUSTRY.}

Chief: A. D. Melvin.

Assistant Chief: A. M. Farrington.

Chief Clerk: Charles C. Carroll.

Animal Husbandry Division: George M. Rommer, chief.

Biochemic Division: M. Donset, chief.

Dairy Division: B. H. RAwL, chief.

Field Inspection Division: R. A. RAMSAY, chief.

Meat Inspection Division: R. P. STEDdoM, chief.

Pathological Division: JoHN R. MoHLER, chief.

Quarantine Division: RichaRd W. HICKMAN, chief.

Zoological Division: B. H. Ransom, chief.

Experiment Station: E. C. SCHROEDER, superintendent.

Editor: James M. Pickens.

\section{DAIRY DIVISION.}

B. H. RAwL, chief.

HeLmer RABILD, in charge of Dairy Farming Investigations.

S. C. Thompson, in charge of Dairy Manufacturing Investigations.

L. A. Rogers, in charge of Rescarch Laboratories.

ERNEST KELLY, in charge of Market Milk Investigations.

ROBERT MCADAM, in charge of Renovated Butter Inspection.

ADDITIONAL COPIES of this publication $A$ may be procured from the SUP ERINTENDENT of Documents, Government Printing Office, Washington, D. C., at 10 cents per copy 


\section{LE'TTER OF TRANSMITTAL.}

U. S. Department of Agriculture, Bureau of Animal Industry, Washington, D. C., October $\%, 1912$.

SIR: I have the honor to transmit herewith for publication in the bulletin series of this bureau a manuscript entitled " $A$ Study of the Bacteria Which Survive Pasteurization," by Messrs. S. Henry Ayers and William T. Johnson, jr., of the Dairy Division.

Respectfally,

Hon. James Wilson,

A. D. Melvin, Chief of Bureau.

Secretary of Agriculture. 


\section{Digitized by the Internet Archive in 2007 with funding from Microsoft Corporation}




\section{CONTENTS.}

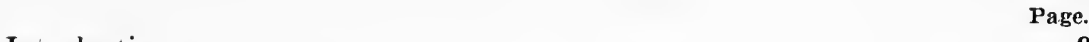

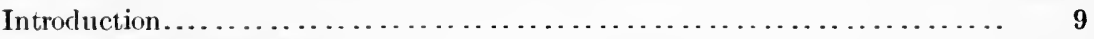

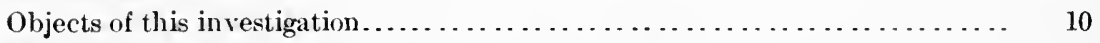

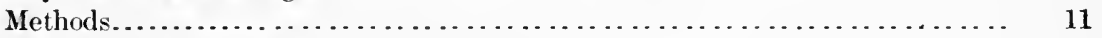

Temperatures used throughout the country ...................... 12

Bacterial reductions by laboratory pasteurization, using the "holder" process .. 13

Bacterial reductions at $60^{\circ} \mathrm{C} .\left(140^{\circ} \mathrm{F}\right.$ ) and $65.6^{\circ} \mathrm{C} .\left(150^{\circ} \mathrm{F}.\right) \ldots \ldots \ldots \ldots$

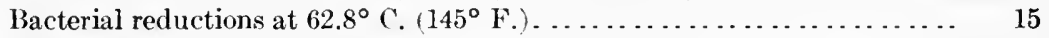

The control of pasteurization................................. 16

Effect of long heating on bacteria in milk....................... 17

Three hours' pasteurization.............................. 17

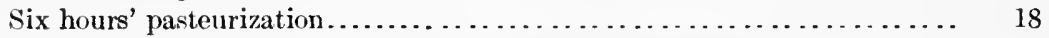

Effect of sudden cooling on the bacteria in pasteurized milk............. 20

Groups of bacteria which survive pasteurization .................... 21

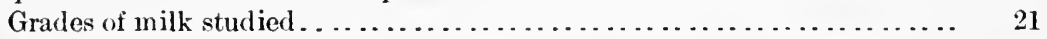

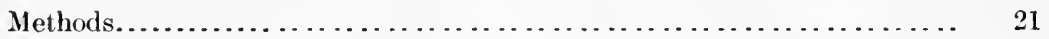

The bacterial groups in grade $A$ milk before and after pasteurization for

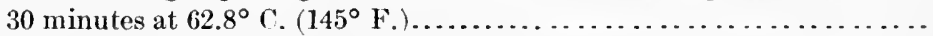

The bacterial groups in grade $\mathrm{A}$ milk before and after pasteurization for

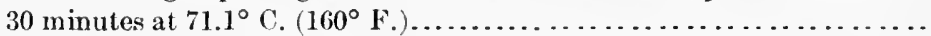

The bacterial groups in grade $\mathrm{B}$ milk before and after pasteurization for

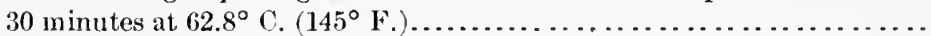

The bacterial groups in grade $\mathrm{C}$ milk hefore and after pasteurization for

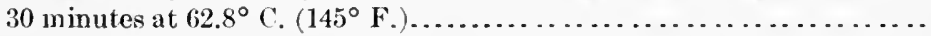

The bacterial groups in milk pasteurized at high temperatures...........

The activity of hacteria of the various groups isolated from raw and pasteurized milk measured by their ability to produce changes in litmus milk after dif-

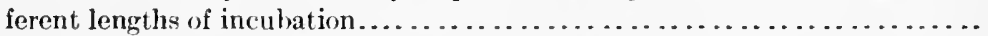

Grade $\mathrm{A}$ nilk before and after pasteurization for 30 minutes at $62.8^{\circ} \mathrm{C}$.

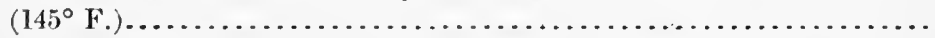

Grade $\Lambda$ milk before and after pasteurization for 30 minutes at $71.1^{\circ} \mathrm{C}$.

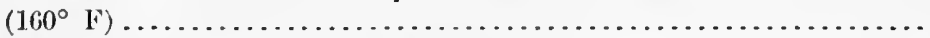

Grade 13 milk beiore and aiter pasteurization for 30 minutes at $62.8^{\circ} \mathrm{C}$.

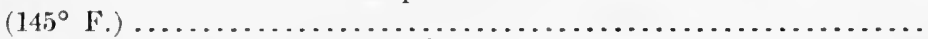

Grade $C$ milk before and after pasteurization for 30 minutes at $62.8^{\circ}($ ?

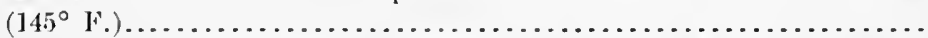

Comparison of the percentage of arid-forming barteria in raw and pastenrized milk

Comparison of the percentage of peptonizing bacterial in raw and pastemrized milk.

Average percentages of the bacterial groups of raw milk which survive jasteuri-

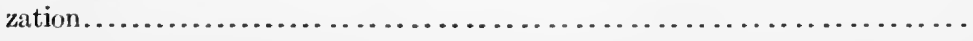


The effect of pasteurization on the number of bacteria of different groups in milk

Page.

The bacterial development in milk pasteurized in the laboratory and held at different temperatures.

Qualitative study of the groups of bacteria which survive pasteurization......

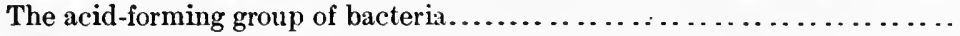

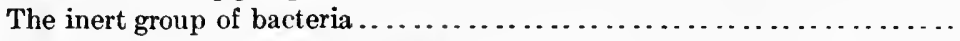

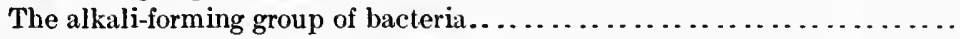

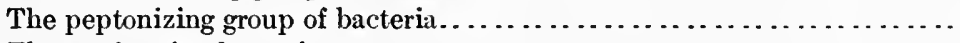

The gas-forming bacteria.

Thermal death points of bacteria which survive pasteurization................

The possible use in pasteurization of acid-forming bacteria of high thermal death point.

Qualitative study of the complete bacterial flora of one sample of pasteurized milk.

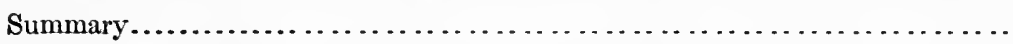

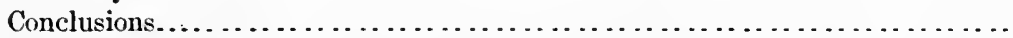

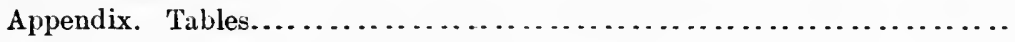




\section{ILLUSTRATIONS.}

FIGURE 1. Bacterial reduction during pasteurization for three hours at $54.4^{\circ}$ C. $\left(130^{\circ} \mathrm{F}.\right), 57.2^{\circ} \mathrm{C} .\left(135^{\circ} \mathrm{F}.\right)$, and $60^{\circ} \mathrm{C} .\left(140^{\circ} \mathrm{F}.\right) \ldots \ldots \ldots$

2. Bacterial reduction during pasteurization for six hours at $62.8^{\circ} \mathrm{C}$. $\left(145^{\circ}\right.$ F.). Plotted after one-half, three, and six hours.........

3. Bacterial reduction during pasteurization for six hours at $62.8^{\circ} \mathrm{C}$. $\left(145^{\circ}\right.$ F.). Plotted every half hour.

4. Comparison of the milk-tube and plate method for the determination of the bacterial groups in milk.

5. Bacterial groups of grade $\Lambda$ milk before and after pasteurization for 30 minutes at $62.8^{\circ} \mathrm{C} .\left(145^{\circ} \mathrm{F}\right.$. $)$.

6. Bacterial groups in grade $\mathrm{A}$ milk before and after pasteurization for 30 minutes at $71.1^{\circ} \mathrm{C} .\left(160^{\circ} \mathrm{F}.\right) \ldots \ldots \ldots \ldots \ldots \ldots \ldots \ldots \ldots \ldots \ldots \ldots \ldots \ldots \ldots \ldots$

7. Bacterial groups in grade $B$ milk before and after pasteurization

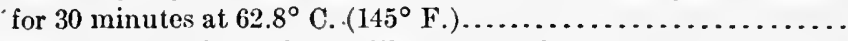

8. Bacterial groups in grade $\mathrm{C}$ milk before and after pasteurization for

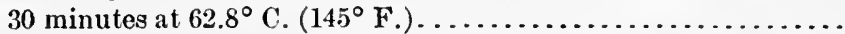

9. Bacterial groups which survive pasteurization for 30 minutes at $76.7^{\circ}$ C. $\left(170^{\circ}\right.$ F. $), 82.2^{\circ}$ C. $\left(180^{\circ}\right.$ F. $), 87.8^{\circ} \mathrm{C} .\left(190^{\circ}\right.$ F. $)$, and $93.3^{\circ} \mathrm{C}$ $\left(200^{\circ} \mathrm{F}\right.$.)

10. ('hanges in the bacterial group relations in grade $A$ milk when determined by litmus milk reactions after different lengths of incubation. Milk pasteurized at $62.8^{\circ} \mathrm{C} .\left(145^{\circ} \mathrm{F}\right.$.) for 30 minutes. .

11. Changes in the bacterial group relations in grade $\mathrm{A}$ milk when determined by litmus milk reactions after different lengths of incubation. Milk pasteurized at $71.1^{\circ} \mathrm{C} .\left(160^{\circ} \mathrm{F}\right.$.) for 30 minutes...

12. Changes in the hacterial group relations in grade $B$ milk when determined by litmus milk reactions after different lengths of incu-

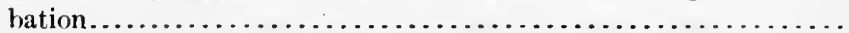

13. Changes in the bacterial group relations in grade $\mathrm{C}$ milk when determined by litmus milk reactions after different lengths of incu-

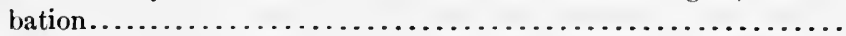

14. Comparison of the percentage of the acid-forming bacteria in raw and

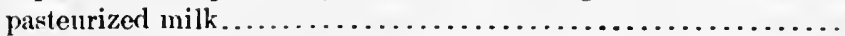

15. Comparison of the percentage of the peptonizing bacteria in raw and

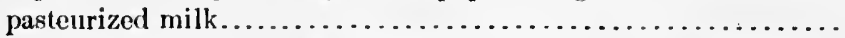

16. Daily changes in the bacterial group relations in pasteurized milk.

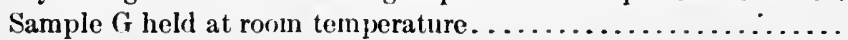

17. Daily changes in the bacterial group relations in pasteurized milk.

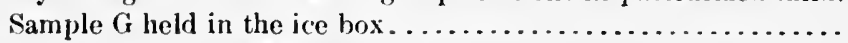

18. Daily changes in the bacterial group relations in pasteurized milk.

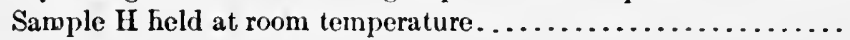


Figure 19. Daily changes in the bacterial group relations in pasteurized milk.

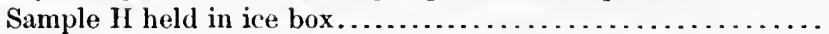

20. Daily changes in the bacterial group relations in pasteurized milk. Sample K held at room temperature....................

21. Daily changes in the bacterial group relations in pasteurized milk.

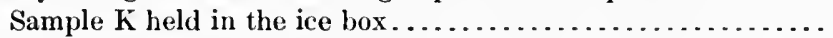

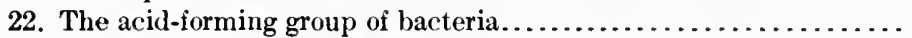

23. The alkali-forming group of bacteria...................... 45

24. The peptonizing group of bacteria..................... 46

25. Apparatus for the determination of gas production in milk...... 48

26. Gas produced by culture Z......................... 49

27. A series. Cultures from. milk pasteurized at $60^{\circ} \mathrm{C}$. $\left(140^{\circ} \mathrm{F}\right.$.) for 30

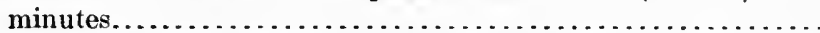

28. B series. Cultures from milk pasteurized at $65.6^{\circ} \mathrm{C}$. $\left(150^{\circ} \mathrm{F}\right.$.) for 30 minutes......................................... 56

29. The hypothetical relation of the bacterial groups to raw and pas-

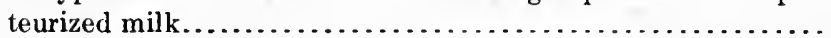

30. The hypothetical relation of the bacterial groups in raw and pas-

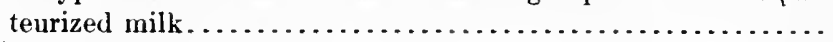




\section{A STUDY OF BACTERIA WHICH SURVIVE PASTEURIZATION.}

\section{INTRODUCTION.}

The bacteria which survive the process of pasteurization are of great importance, since they form the foundation for the subsequent bacterial development. It is well known that the most efficient pasteurization will not destroy all of the microorganisms in milk. The process must, then, leave a certain number of bacteria which it is impossible to destroy at the temperatures employed.

The prevailing view has been that the organisms left after heating were largely of the peptonizing spore-forming type, with some few inert forms. This idea was based on the belief that all vegetative cells were destroyed at temperatures below the minimum pasteurizing temperature of $60^{\circ} \mathrm{C} .\left(140^{\circ} \mathrm{F}\right.$.).

Theoretically, then, only spore-forming organisms should survive pasteurization. This view was strengthened by numerous investigations of the bacterial flora of boiled milk or milk pasteurized at extremely high temperatures. As lower temperatures came gradually into use investigations indicated that vegetative cells might have higher thermal death points than was generally believed. Russell and Hastings ${ }^{1}$ found a micrococeus which was capable of standing a temperature of $76^{\circ} \mathrm{C} .\left(168.8^{\circ} \mathrm{F}\right.$.) for 10 minutes. Other investigators pointed out that lactic acid bacteria occasionally appeared in pasteurized milk and yet the thermal death point of the lactic acid bacteria was stated to be in the neighborhood of $57.2^{\circ}$ to $60^{\circ}$ C. $\left(135^{\circ}-140^{\circ} \mathrm{F}\right.$.). Rogers ${ }^{2}$ found that in milk pasteurized at $85^{\circ}$ C. $\left(185^{\circ} \mathrm{F}\right.$.) by the "flash" process lactic acid bacteria oceasionally survived. Marshall ${ }^{3}$ states "It is largely supposed that in pasteur-, ized milk the lactic acid bacteria are killed. 'This is largely true but not universally." Mazé $e^{4}$ found that the ordinary lactic acid bacteria

\footnotetext{
1 Russell, II. L., and Hastings, E. G. A micrococeus, the thermal death limit of which is $76^{\circ} \mathrm{C}$. Centralblatt für Bcktoriologie, Parasitenkunde und Inlektionskrankheiten, Abteilung 2, vol. 8, No. 11, pp. 339-342. Jena, Mis. 13, 1902.

2 Rogers, $\mathrm{L}$. A. Tho bacteria of pasteurized end unpasteurized milk under laboratory conditions. United States Department of A griculture, Bureau oi Antmal Industry, Bulletin 73. Washington, 1905.

${ }^{3}$ Marshall, C. F. Pastcurization of milk. Michigan Agriculfural Experiment Station, Bulletin 147. Agricultural College, August, 1897.

4 Mazé, p. Pasteurization du latl destine is la consommation. L'Industrie Latitiòre, vol. 32, No. 8, pp. 121-127. Tarls, Feb. 24, 1907.
} 
were destroyed by five minutes' heating at temperatures between $55^{\circ}$ and $65^{\circ} \mathrm{C}$. $\left(131^{\circ}\right.$ and $149^{\circ} \mathrm{F}$.), but that lactic acid bacteria existed which resist five minutes' heating at $75^{\circ} \mathrm{C}$. $\left(167^{\circ} \mathrm{F}\right.$.). When milk was pasteurized in bottles for 60 minutes at $65^{\circ} \mathrm{C}$. $\left(149^{\circ} \mathrm{F}\right.$.), Gerber ${ }^{1}$ and Weiske found that the bacteria which resisted belonged for the most part to the inoffensive lactic bacilli. An investigation of commercially pasteurized milk in this country carried on by the authors ${ }^{2}$ showed the presence of high-temperature resisting lactic-acid bacteria, the thermal death point of one of which was $77.8^{\circ} \mathrm{C}$. $\left(172^{\circ} \mathrm{F}\right.$.) with a 10 minutes' exposure and $75.6^{\circ} \mathrm{C}$. $\left(168^{\circ} \mathrm{F}\right.$.) with a 30 minutes' heating. It was further found that commercially pasteurized milk always soured. Kohler ${ }^{3}$ and Tonney, after studying pasteurized milk in Chicago, concluded that reinfection was the cause of the souring of lieated milk.

It is evident that the knowledge of the bacteria which actually survive pasteurization is very limited.

\section{OBJECTS OF THIS INVESTIGATION.}

The general object of this investigation was to study quantitatively and qualitatively the bacteria which survive pasteurization under conditions which excluded any possibility of recontamination of the milk after pasteurization.

The special objects were as follows:

1. To ascertain the average temperature of pasteurization in both the "holder" and "flash" process used throughout the country.

2. To determine the effect of various pasteurizing temperatures for one-half hour's exposure upon the bacteria in different grades of milk.

3. To study the effect of holding periods longer than one-half hour during pasteurization.

4. To determine the effect of sudden cooling on bacteria after pasteurization.

5. To study quantitatively the bacterial groups which survive pasteurization at various temperatures.

6. To trace the development of the various bacterial groups in pasteurized milk held at different temperatures.

7. To study qualitatively the bacteria which survive pasteurization.

1 Gerber, N., and Weiske, P. Pasteurisation des flacons dans la grande industrie (pasteurisation avec agitation). Revue Générale du Lait, vol. 2, No. 8, pp. 169-177. Lierre, Jan. 30, 1909.

2 Ayers, S. Henry, and Johnson, W. T., jr. The bacteriology of commerciaily pasteurized and raw market milk. United States Department of Agriculture, Bureau of Animal Industry, Bulletin 126. Washington, 1910.

\& Kohler, Gottlried and Tonney, F.'o. The control of pasteurization. Joumal of the American Medical Association, vol. 56, No. 10, pp. 713-718. Chicago, Mar. 11, 1911. 


\section{METHODS.}

In this investigation the technique of plating and the preparation of becf infusion agar with a reaction of 1.5 (Fuller's scale) was carried out according to the recommendations of the committee of standard methods for the bacteriological analyses of milk. ${ }^{1}$ In the preparation of fermentation bouillons and litmus lactose gelatin, Liebig's beef extract was used as a basis.

Fermentation bouillons were prepared by dissolving 4 grams of Liebig's beef extract and 10 grams of Witte's peptone in a liter of water and correcting reaction to 0.0 (Fuller's scale). The broth was then brought up to the sterilizing temperature for five minutes and filtered. When a clear filtrate was obtained, 0.5 per cent potassium dibasic phosphate and 1 per cent of the substance to be fermented was dissolved in it. The following substances were used to test the fermenting ability of the bacteria:

Sugars: Dextrose, galactose, lactose, saccharose, raffinose. Alcohols: Mannite, glycerin. Starches: Inulin, wheat starch. Glucoside: Salicin.

The ability of the bacteria to reduce nitrates to nitrites was shown by growing the organisms in a bouillon composed of 0.1 per cent Witte's peptone and 0.02 per cent potassium nitrate (nitrite-free) for 14 days at $30^{\circ} \mathrm{C}$. $\left(86^{\circ} \mathrm{F}\right.$.) and then testing for the presence of nitrites. The liquefaction of gelatin by an organism was determined by inoculating with a drop of milk culture on the surface of the tube of medium and incubating for 30 days at $18^{\circ} \mathrm{C} .\left(64.4^{\circ} \mathrm{F}\right.$.) and then measuring the depth of liquefaction.

Special media.-For ordinary routine plating of a milk sample, and especially for the determination of the peptonizing bacteria, a casein agar was devised, ${ }^{2}$ consisting of dissolved chemically pure casein and agar, with a final reaction slightly acid. In isolating gas formers, Smith tubes containing lactose peptone bile ${ }^{3}$ and dextrose liver broth ${ }^{4}$ were used.

All samples of milk were pasteurized in sterile flasks in the laboratory. At all the temperatures except $60^{\circ} \mathrm{C}$. $\left(140^{\circ} \mathrm{F}\right.$.) and $65.6^{\circ} \mathrm{C}$. $\left(150^{\circ} \mathrm{F}\right.$.), 800 cubic centimeters of milk were heated. During the few experiments at those temperatures only 100 cubic centimeters of milk were used. In all the experiments the period of heating was 30 minutes from the time the pasteurizing temperature

\footnotetext{
1 Report of the Committee on Standard Methods of Bacterial Milk Analysis. Ameriean Journal of Public 11 ygiene, new series, vol. 6, No. 2, pp. 315-345. Columbus, Ohio, May, 1910.

2 Ayers, $\mathrm{S}$, Henry. Casein media adapted to determining bacteria in milk. United States Department of Agriculture, Bureau of Animal Industry, Twenty-elghth Annual Report, 1911 (in press).

Jackson, Daniel D. A new solution for the presumptive test for Bacillus coli. Biological Studies of Puplls of W. T. Sedgwick, pp. 292-299. Boston, 1906.

- Jackson, D. D., and Mfuer, 'T.C. Liver broth. A medium for the determination of gas-forming bacteria in water and sewage. Journal of the Ameriean Publie Ilealth Association, vol. I, No. 12, pp. 927-929. Urbana, III., Deceniber, 1911.
} 
was reached. The methods employed throughout this investigation make the results comparable with those obtained by pasteurization in sealed bottles.

\section{TEMPERATURES USED THROUGHOUT THE COUNTRY.}

It was necessary to ascertain the temperatures most universally used at milk plants in this country in order that an average temperature might be employed in these experiments. Circular letters were therefore sent to pasteurizing plants in nearly all cities with a population of over 25,000 . Replies showed that the average temperature with the "holder" process was $62.8^{\circ} \mathrm{C}$. $\left(145^{\circ} \mathrm{F}\right.$.). With the "flash" process $71.1^{\circ} \mathrm{C}$. $\left(160^{\circ} \mathrm{F}\right.$.) was about the average. The reports from 219 milk plants which pasteurized showed that 75 used the "holder" process and 144 the "flash" process.

Assuming that the correct temperatures for pasteurization are from $60^{\circ}$ to $65.6^{\circ} \mathrm{C}$. $\left(140^{\circ}\right.$ to $150^{\circ} \mathrm{F}$.) with the "holder" process, then 62 of the 75 pasteurized at the proper temperature, one used a temperature too low, $54.4^{\circ}$ to $57.2^{\circ} \mathrm{C} .\left(130^{\circ}\right.$ to $135^{\circ} \mathrm{F}$.), and 12 too high, ranging from $66.7^{\circ}$ to $76.7^{\circ} \mathrm{C}$. $\left(152^{\circ}\right.$ to $170^{\circ} \mathrm{F}$.). With the "flash" process the correct temperature was assumed to be $71.1^{\circ} \mathrm{C}$. $\left(160^{\circ} \mathrm{F}\right.$.). As there is usually a variation in the range of temperature during pasteurization, the maximum and the minimum given by each plant have been averaged. When the average was $71.1^{\circ} \mathrm{C} .\left(160^{\circ} \mathrm{F}\right.$.) it was assumed that the proper temperature was used. It was found that of 144 plants using the "flash" process only 61 used the correct temperature, 61 pasteurized too low and 22 too high. The low temperatures ran down to $60^{\circ} \mathrm{C}$. $\left(140^{\circ} \mathrm{F}\right.$.), the high temperatures up to $82.2^{\circ} \mathrm{C}$. $\left(180^{\circ} \mathrm{F}\right.$.). These figures show a decided lack of uniformity of temperatures used in pasteurization. The temperatures below $60^{\circ} \mathrm{C}$. $\left(140^{\circ} \mathrm{F}\right.$.) with the "holder" process render no protection as far as the destruction of pathogenic organisms is concerned, while those above $65.6^{\circ} \mathrm{C}$. $\left(150^{\circ} \mathrm{F}\right.$.) only increase the cost of pasteurization and tend to reduce the cream line. The same is true when using the "flash" process below or above temperatures ranging from $71.1^{\circ}$ to $73.9^{\circ} \mathrm{C}$. $\left(160^{\circ}\right.$ to $165^{\circ} \mathrm{F}$.).

As pasteurization is practiced, the milk might have been heated from 1 minute at $60^{\circ} \mathrm{C} .\left(140^{\circ} \mathrm{F}\right.$.) to 30 minutes at $76.7^{\circ} \mathrm{C} .\left(170^{\circ} \mathrm{F}\right.$. $)$ and it would all be known as pasteurized milk. This lack of uniformity is undoubtedly due to a misunderstanding of the effects of heat on the bacterial flora of milk. 


\section{BACTERIAL REDUCTIONS BY LABORATORY PASTEURIZATION, USING THE "HOLDER" PROCESS.}

Since regulations often require a definite percentage bacterial reduction and as the efficiency of pasteurizers is based on the same figures, it seemed advisable to study the quantitative bacterial reductions under exact laboratory conditions.

BACTERIAL REDUCTIONS AT $60^{\circ}$ C. $\left(140^{\circ}\right.$ F.) AND $65.6^{\circ}$ C. $\left(150^{\circ}\right.$ F. $)$.

In these experiments the milk was heated in sterile flasks in a water bath at a temperature of $60^{\circ} \mathrm{C} .\left(140^{\circ} \mathrm{F}\right.$.) and $65.6^{\circ} \mathrm{C} .\left(150^{\circ} \mathrm{F}\right.$.) for a period of 30 minutes. The temperature recorded by a thermometer in the milk was maintained for the full 30 minutes. Twelve samples of milk from dairy $\mathrm{X}$ were used. Each was divided and a portion pasteurized at both temperatures. The counts were made on litmus lactose gelatin incubated at $18^{\circ} \mathrm{C}$. $\left(64.4^{\circ} \mathrm{F}\right.$.) for six days. Table 1 shows the total counts and efficiency of the process as determined by the percentage bacterial reduction. An examination of the table shows that the raw milk was of poor quality, having a high bacterial count. The samples pasteurized at $60^{\circ} \mathrm{C}$. $\left(140^{\circ} \mathrm{F}\right.$.) showed a high count, while the same samples at $65.6^{\circ} \mathrm{C} .\left(150^{\circ} \mathrm{F}\right.$.) showed a low count, as a rule. The effect of the few degrees of heat may be plainly seen. At the lower temperature 9 out of the 12 samples showed a reduction of less than 99 per cent, while at the higher temperature only 4 showed less than a 99 per cent reduction.

TA BLE 1.-Percentage reduction of bacteria by laboratory pasteurization, using the "holder" process-Raw milk obtained from dairy $X$.

\begin{tabular}{|c|c|c|c|c|c|}
\hline \multirow{2}{*}{$\begin{array}{c}\text { Sample } \\
\text { No. }\end{array}$} & \multirow{2}{*}{$\begin{array}{c}\text { Raw milk. } \\
\text { Total count. }\end{array}$} & \multicolumn{2}{|c|}{$\begin{array}{l}\text { Pasteurized at } 60^{\circ} \mathrm{C} \text {. } \\
\left(140^{\circ} \text { F.) for } 30\right. \\
\text { minutes. }\end{array}$} & \multicolumn{2}{|c|}{$\begin{array}{l}\text { Pas te urized at } \\
65.6^{\circ} \mathrm{C} \text {. (150 } \mathrm{F} \text {.) } \\
\text { for } 30 \text { minutes. }\end{array}$} \\
\hline & & $\begin{array}{l}\text { Total } \\
\text { eount. }\end{array}$ & $\begin{array}{l}\text { Percent- } \\
\text { age re- } \\
\text { duction. }\end{array}$ & $\begin{array}{l}\text { Total } \\
\text { eount. }\end{array}$ & $\begin{array}{l}\text { Pereent- } \\
\text { age re- } \\
\text { duction. }\end{array}$ \\
\hline $\begin{array}{r}1 \\
2 \\
3 \\
4 \\
5 \\
6 \\
7 \\
8 \\
9 \\
10 \\
11 \\
12\end{array}$ & $\begin{array}{r}33,900,000 \\
4,900,000 \\
5,060,000 \\
850,000 \\
6,100,000 \\
8,400,000 \\
1,670,000 \\
4,100,000 \\
1,120,000 \\
4,800,000 \\
4,400,000 \\
12,300,000\end{array}$ & $\begin{array}{r}200,000 \\
118,000 \\
130,000 \\
32,000 \\
20,200 \\
23,000 \\
244,000 \\
74,000 \\
54,000 \\
153,000 \\
206,000 \\
196,000\end{array}$ & $\begin{array}{l}99.41 \\
97.59 \\
97.45 \\
96.23 \\
99.66 \\
99.72 \\
82.99 \\
98.19 \\
95.00 \\
96.81 \\
95.31 \\
98.41\end{array}$ & $\begin{array}{r}9,800 \\
12,300 \\
25,100 \\
25,500 \\
12,100 \\
12,600 \\
72,000 \\
28,500 \\
19,900 \\
19,800 \\
69,000 \\
40,000\end{array}$ & $\begin{array}{l}99.97 \\
99.74 \\
99.50 \\
97.00 \\
99.80 \\
99.85 \\
95.68 \\
99.30 \\
98.22 \\
99.58 \\
98.43 \\
99.67\end{array}$ \\
\hline
\end{tabular}

The effect of pasteurization on the bacterial content of another series of 12 samples from dairy $\mathrm{Y}$ was studied in the same way. The results are shown in Table 2 . It may be seen that the milk was of far better quality than that from dairy $\mathrm{X}$. Tho counts of 
milk pasteurized at $60^{\circ} \mathrm{C} .\left(140^{\circ} \mathrm{F}\right.$.) were low and still lower at the higher temperature. In spite of the low counts the percentage bacterial reductions were not so great as when a poor grade of milk was pasteurized as shown in Table 1. Eleven out of twelve samples showed a reduction of less than 99 per cent at $60^{\circ} \mathrm{C} .\left(140^{\circ} \mathrm{F}\right.$.). At $65.6^{\circ} \mathrm{C}$. $\left(150^{\circ} \mathrm{F}\right.$.) 7 out of 12 showed a bacterial reduction of less than 99 per cent. A comparison of Tables 1 and 2 show that the bacterial content after pasteurization of the better grade of milk was far lower than that of milk-from dairy $X$, which contained a large number of bacteria before heating. If, however, the efficiency of the process is studied, the higher percentage bacterial reductions will be found in Table 1, where the milk was of poor quality. It is very evident that the percentage bacterial reduction is of no value in determining the quality of pasteurized milk. Compare, for example, sample No. 1 in Table 1 with sample No. 3 in Table $2 . \quad$ In the first case, the raw milk contained $33,900,000$ bacteria per cubic centimeter and after pasteurization, 200,000 per cubic centimeter, which is a percentage reduction of 99.41 per cent. In the second case, raw milk, 128,000 bacteria per cubic centimeter and after pasteurization 13,900 per cubic centimeter, which is a reduction of only 89.14 per cent. A 99.41 per cent reduction against 89.14 per cent, and yet the pasteurized milk in which only 89.14 per cent of the bacteria were destroyed was far superior in its bacterial content.

TABLE 2,-Percentage reduction of bacteria by laboratory pasteurization, using the "holder" process-Raw milk obtained from dairy $Y$.

\begin{tabular}{|c|c|c|c|c|c|}
\hline \multirow{2}{*}{$\begin{array}{l}\text { Sample } \\
\text { No. }\end{array}$} & \multirow{2}{*}{ Raw milk. } & \multicolumn{2}{|c|}{$\begin{array}{l}\text { Pasteurized at } 60^{\circ} \mathrm{C} \text {. } \\
\left(140^{\circ} \mathrm{F} .\right) \text { for } 30 \\
\text { minutes. }\end{array}$} & \multicolumn{2}{|c|}{$\begin{array}{l}\text { Pas te u rized at } \\
65.6^{\circ} \mathrm{C} \text {. (150 } 150^{\circ} \mathrm{F} \text {.) } \\
\text { for } 30 \text { minutes. }\end{array}$} \\
\hline & & $\begin{array}{l}\text { Total } \\
\text { count. }\end{array}$ & $\begin{array}{l}\text { Percent- } \\
\text { age re- } \\
\text { duction. }\end{array}$ & $\begin{array}{l}\text { Total } \\
\text { count. }\end{array}$ & $\begin{array}{l}\text { Percent- } \\
\text { age re- } \\
\text { duction. }\end{array}$ \\
\hline 1 & 2.500 .000 & 27.600 & 98.89 & 4,210 & 99.83 \\
\hline 2 & 000 & 13,1 & 98.79 & 2,3 & 99.78 \\
\hline 3 & 128 & 13,9 & 89 & 5,670 & 95.57 . \\
\hline 4 & 000 & 7,500 & 94.96 & 3,100 & 97.91 \\
\hline 5 & & 16,400 & 97.26 & 11,100 & 98.15 \\
\hline 6 & & , & 97. & 1,0 & 99.14 \\
\hline 7 & 0 & $\begin{array}{l}1,890 \\
1,890\end{array}$ & 98.87 & 3,230 & 98.07 \\
\hline 8 & & $2, \mathrm{c}$ & & 2,720 & 96.76 \\
\hline 9 & 160 & 5,110 & 96.80 & 2,0 & 98.74 \\
\hline 10 & 590 & 13,200 & 97.76 & 7,1 & 98.79 \\
\hline 11 & 2,90 & & 99 & 20 , & 99.29 \\
\hline 12 & $1,170,000$ & 34,100 & 97.08 & 3,560 & 99.69 \\
\hline
\end{tabular}

The uselessness of figures in expressing percentage reductions is further shown in Table 3. The bacterial content of 12 samples of milk before and after pasteurization has been averaged, two grades of milk having been used. While the percentage reduction is approximately the same at $60^{\circ} \mathrm{C} .\left(140^{\circ} \mathrm{F}\right.$.) the average bacterial counts vary 
widely, one being 124,000 per cubic centimeter, the other only 13,900 per cubic centimeter. At $65.6^{\circ} \mathrm{C}$. $\left(150^{\circ} \mathrm{F}\right.$.) while the percentage reduction is increased to 98 per cent, the bacterial content holds the same relation as at the lower temperature.

TABLE 3.-Comparison of the average bacterial content of two grades of milk and percentcge reduction in bacteria by pasteurization at $60^{\circ} \mathrm{C} .\left(140^{\circ} \mathrm{F}\right.$.) and $65.6^{\circ} \mathrm{C} .\left(150^{\circ} \mathrm{F}\right.$.).

AVERAGE OF 12 SAMPLES IN EACH GRADE.

\begin{tabular}{|c|c|c|c|c|c|}
\hline \multirow{2}{*}{ Grade. } & \multirow{2}{*}{$\begin{array}{c}\text { Raw milk. } \\
\begin{array}{c}\text { Bacteria } \\
\text { per cubic } \\
\text { centimeter. }\end{array}\end{array}$} & \multicolumn{2}{|c|}{$\begin{array}{l}\text { Past eurized at } 60^{\circ} \mathrm{C} \text {. } \\
\left(140^{\circ} \text { F.) } 30 \text { minutes. }\right.\end{array}$} & \multicolumn{2}{|c|}{$\begin{array}{l}\text { Pasteurized at } 65.6^{\circ} \mathrm{C} \text {. } \\
\left(150^{\circ} \text { F. }\right) 30 \text { minutes. }\end{array}$} \\
\hline & & $\begin{array}{c}\text { Bacteria } \\
\text { per cubic } \\
\text { centimeter. }\end{array}$ & $\begin{array}{l}\text { Percent- } \\
\text { age re- } \\
\text { duction. }\end{array}$ & $\begin{array}{c}\text { Bacteria } \\
\text { per cubic } \\
\text { centimeter. }\end{array}$ & $\begin{array}{l}\text { Percent- } \\
\text { age re- } \\
\text { duction. }\end{array}$ \\
\hline $\begin{array}{l}\text { Grade } 1 \ldots \\
\text { Grade } 2 \ldots\end{array}$ & $\begin{array}{r}7,300,000 \\
804,000\end{array}$ & $\begin{array}{r}124,000 \\
13,900\end{array}$ & $\begin{array}{l}96.39 \\
96.95\end{array}$ & $\begin{array}{r}28,900 \\
5,500\end{array}$ & $\begin{array}{l}98.72 \\
98.40\end{array}$ \\
\hline
\end{tabular}

BACTERIAL REDUCTION AT $62.8^{\circ}$ C. $\left(145^{\circ}\right.$ F.).

Another scries of 28 samples of milk was studied in a similar manner. The results are shown in Table 4. In this series a temperature of $62.8^{\circ} \mathrm{C}$. $\left(145^{\circ} \mathrm{F}\right.$.) was used for a period of 30 minutes. All of the samples of raw milk contained over $1,000,000$ bacteria per cubic centimeter. The bacterial counts were made on infusion agar, incubated at $30^{\circ} \mathrm{C}$. $\left(86^{\circ} \mathrm{F}\right.$.) for six days. It may be seen from the table that the percentage reductions were high, only 3 out of 28 being less than 99 per cent; however, 13 of the pasteurized samples contained over 20,000 bacteria per cubic centimeter.

TABLE 4.-Efficiency of the "holder" process of pasteurization under laboratory conditions, using raw milk with a bacterial content over 1,000,000 per cubic centimeter.

\begin{tabular}{|c|c|c|c|c|c|c|c|}
\hline \multirow{2}{*}{$\begin{array}{l}\text { Sampie } \\
\text { No. }\end{array}$} & \multirow{2}{*}{$\begin{array}{c}\text { Raw milk. } \\
\text { Bacteria } \\
\text { per cubic } \\
\text { centimetcr. }\end{array}$} & \multicolumn{2}{|c|}{$\begin{array}{c}\text { Pasteurized at } 62.8^{\circ} \\
\text { C. }\left(145^{\circ} \mathrm{F} .\right) \text { for } 30 \\
\text { minutes. }\end{array}$} & \multirow{2}{*}{$\begin{array}{c}\text { Sampie } \\
\text { No. }\end{array}$} & \multirow{2}{*}{$\begin{array}{l}\text { Raw milk. } \\
\text { Bacteria } \\
\text { per cuble } \\
\text { centimeter. }\end{array}$} & \multicolumn{2}{|c|}{$\begin{array}{l}\text { Pasteurized at } 62.8^{\circ} \\
\text { C. }\left(145^{\circ} \mathrm{F} \text {.) for } 30\right. \\
\text { minutes. }\end{array}$} \\
\hline & & $\begin{array}{l}\text { Bacteria } \\
\text { per cu- } \\
\text { bic cen- } \\
\text { timeter. }\end{array}$ & $\begin{array}{l}\text { Percent- } \\
\text { age reduc- } \\
\text { tion. }\end{array}$ & & & $\begin{array}{l}\text { Bactcria } \\
\text { per cu- } \\
\text { bie centi- } \\
\text { meter. }\end{array}$ & $\begin{array}{l}\text { l'ercent- } \\
\text { age reduc- } \\
\text { tion. }\end{array}$ \\
\hline 1 & $16,800,000$ & $8.5,000$ & 99.49 & 15 & $12,200,000$ & 33,300 & 99.72 \\
\hline 2 & $91,000,000$ & 14,400 & 99.98 & 16 & $28,200,000$ & 127,000 & 09.54 \\
\hline 3 & $15,900,000$ & 18,200 & 99.88 & 17 & $6,480,000$ & 2,400 & 99.96 \\
\hline 4 & $90,000,000$ & 5,800 & 99.99 & 18 & $4,540,000$ & 9,500 & 99.97 \\
\hline 5 & $19,800,000$ & 41,000 & 99.79 & 19 & $2,460,000$ & 13,600 & 99.44 \\
\hline 6 & $105,000,000$ & 17,500 & 99.98 & 20 & $4,900,000$ & 9,900 & 99,79 \\
\hline 7 & $47,300,000$ & 8,900 & 99.98 & 21 & $1,060,000$ & 1,010 & 99.90 \\
\hline 8 & $12,400,000$ & 9,700 & 99.92 & 22 & $2,790,000$ & 8,800 & 09.68 \\
\hline 9 & $8,600,000$ & 15,000 & 99.82 & 23 & $5,400,000$ & 36,600 & 99.32 \\
\hline 10 & $17,800,000$ & 8,900 & 99.95 & 24 & $6,060,000$ & 30,100 & 99.50 \\
\hline 11 & $18,900,000$ & 41,800 & 99.97 & 25 & $1,140,000$ & 1,560 & 99.86 \\
\hline 12 & $15,100,000$ & 39,700 & 99.74 & 26 & $14,600,000$ & 468,000 & 96.79 \\
\hline 13 & $22,000,000$ & 20,400 & 99.90 & 27 & $1,410,000$ & 22,900 & 98.41 \\
\hline 14 & $98,000,000$ & 28,200 & 99.97 & 28 & $1,780,000$ & 26,500 & 98.51 \\
\hline
\end{tabular}


The results of similar experiments using a series of 24 samples of clean milk are shown in Table 5. The bacterial counts of the pastcurized milk were very low as a rule and yet 14 of the 24 samples showed a percentage bacterial reduction of less than 99 per cent. Sample 17 contained, before heating, only 119,000 bacteria per cubic centimeter; after the process the bacterial content was 20,800 , a reduction of only 82.52 per cent. This sample evidently contained a high percentage of resistant bacteria which were able to withstand the process of pasteurization. From these results it is apparent that regulations of boards of health calling for a 99 per cent reduction of bacteria in commercial pasteurization are of no value. As a general rule, it may be said that the higher the bacteria in raw milk the greater the percentage reduction through pasteurization. When the bacterial content of milk is low it is almost always impossible to obtain a 99 per cent reduction of the bacteria. It is also evident that bacterial standards for pasteurized milk must not be set below the limit which it is theoretically possible to obtain. When pasteurizing in the laboratory for a period of 30 minutes at $62.8^{\circ} \mathrm{C}$. $\left(145^{\circ} \mathrm{F}\right.$.) under conditions which permitted no reinfection of the milk, the bacterial content of pasteurized milk was by no means uniform. Sometimes the counts were high and sometimes low and yet the maintenance of the proper temperature of pasteurization would have assured in all cases the same degree of protection from pathogenic organisms.

TABLE 5.-Efficiency of the "holder" process of pasteurization under laboratory conditions, using raw milk with a bacterial content less than 1,000,000 per cubic centimeter.

\begin{tabular}{|c|c|c|c|c|c|c|c|}
\hline \multirow{2}{*}{$\begin{array}{c}\text { Sample } \\
\text { No. }\end{array}$} & \multirow{2}{*}{\begin{tabular}{|c|} 
Raw milk. \\
Bacterla \\
per cubic \\
centimeter.
\end{tabular}} & \multicolumn{2}{|c|}{$\begin{array}{c}\text { Pasteurized at } 62.8^{\circ} \\
\mathrm{C}\left(145^{\circ} \mathrm{F}\right) \text { for } 30 \\
\text { minutes. }\end{array}$} & \multirow{2}{*}{$\begin{array}{c}\text { Sample } \\
\text { No. }\end{array}$} & \multirow{2}{*}{$\begin{array}{c}\text { Raw milk. } \\
\text { Bacteria } \\
\text { per cubic } \\
\text { centimeter. }\end{array}$} & \multicolumn{2}{|c|}{ 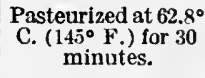 } \\
\hline & & $\begin{array}{l}\text { Bacteria } \\
\text { per cu- } \\
\text { bic cen- } \\
\text { timeter. }\end{array}$ & $\begin{array}{l}\text { Percent- } \\
\text { age reduc- } \\
\text { tion. }\end{array}$ & & & $\begin{array}{l}\text { Bacteria } \\
\text { per cu- } \\
\text { bic cen- } \\
\text { timeter. }\end{array}$ & $\begin{array}{l}\text { Percent- } \\
\text { age reduc- } \\
\text { tion. }\end{array}$ \\
\hline $\begin{array}{r}1 \\
2 \\
3 \\
4 \\
5 \\
6 \\
7 \\
8 \\
9 \\
10 \\
11 \\
12\end{array}$ & $\begin{array}{r}372,000 \\
434,000 \\
540,000 \\
410,000 \\
127,000 \\
143,000 \\
9,300 \\
18,100 \\
19,900 \\
5,300 \\
134,000 \\
300,000\end{array}$ & $\begin{array}{r}910 \\
2,330 \\
4,890 \\
1,170 \\
80 \\
765 \\
90 \\
180 \\
62 \\
34 \\
7,500 \\
7,600\end{array}$ & $\begin{array}{l}99.75 \\
99.46 \\
99.09 \\
99.71 \\
99.93 \\
99.46 \\
99.03 \\
99.00 \\
99.68 \\
99.35 \\
94.40 \\
97.47\end{array}$ & $\begin{array}{l}13 \\
14 \\
15 \\
16 \\
17 \\
18 \\
19 \\
20 \\
21 \\
22 \\
23 \\
24\end{array}$ & $\begin{array}{r}540,000 \\
970,000 \\
162,000 \\
118,000 \\
119,000 \\
137,000 \\
15,600 \\
9,800 \\
18,700 \\
25,900 \\
15,300 \\
9,900\end{array}$ & $\begin{array}{r}11,800 \\
46,000 \\
8,400 \\
9,000 \\
20,800 \\
3,100 \\
300 \\
100 \\
1,340 \\
830 \\
334 \\
320\end{array}$ & $\begin{array}{l}97.81 \\
95.25 \\
94.81 \\
92.37 \\
82.52 \\
97.73 \\
98.07 \\
98.97 \\
92.83 \\
96.79 \\
97.81 \\
96.76\end{array}$ \\
\hline
\end{tabular}

THE CONTrol of Pasteurization.

The control of the process of pasteurization should be by bacterial limits for the milk which is to be used, together with supervision for the maintenance of the proper pasteurizing temperature and protec- 
tion against reinfection. The bacterial content of the milk will then consist only of those organisms which are able to withstand the temperature in use.

\section{EFFECT OF IONG HEATING ON THE BACTERIA IN MILK.}

In some milk plants a holding period longer than half an hour is employed. It seems to be believed that an increased holding period produces a greater bacterial reduction. Several experiments were made at different temperatures and for different periods in order to gain more information on this point.

THREE HOURS' PASTEURIZATION.

In order to determine the effect of a long period of pasteurization, milk was heated in sterile flasks at $54.4^{\circ} \mathrm{C} .\left(130^{\circ}\right.$ F.), $57.2^{\circ}$ C. $\left(135^{\circ} \mathrm{F}\right.$.), and $60^{\circ} \mathrm{C} .\left(140^{\circ} \mathrm{F}\right.$.), and plated every half hour for three hours. The bacterial counts are shown in Table 6. One sample of milk was divided and a portion heated at the two lower temperatures, so the bacterial content of the raw milk was the same. The sample of milk

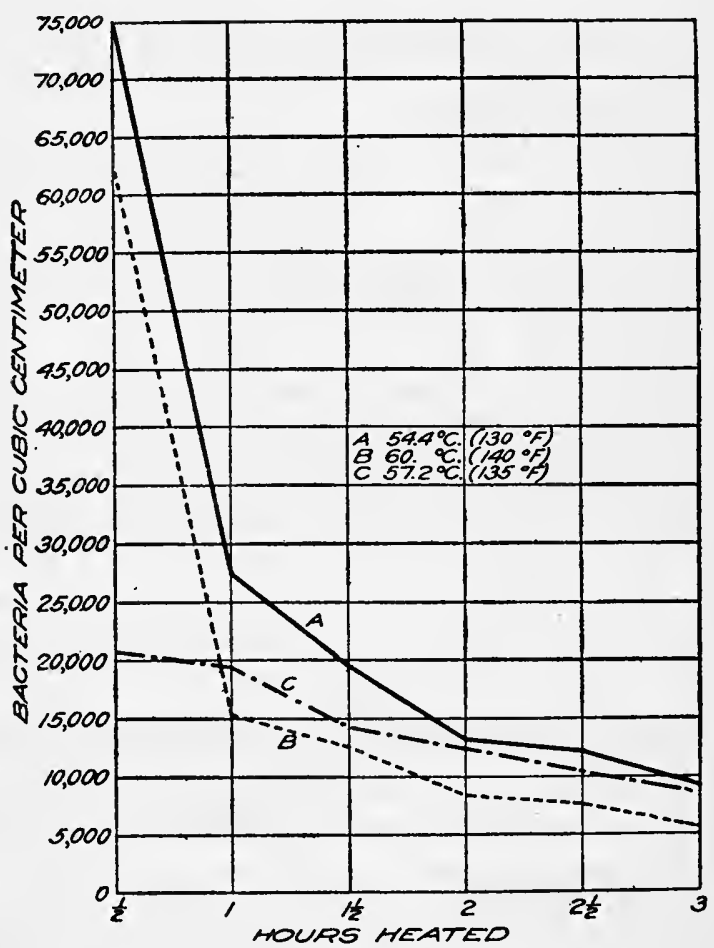

FIG. 1.-Bacterial reduetion during pasteurization for three hours at $54.4^{\circ} \mathrm{C} .\left(130^{\circ} \mathrm{F}.\right), 57.2^{\circ} \mathrm{C} .\left(135^{\circ} \mathrm{F}.\right)$, and $60^{\circ} \mathrm{C} .\left(140^{\circ} \mathrm{F}.\right)$. heated at $60^{\circ} \mathrm{C} .\left(140^{\circ} \mathrm{F}\right.$.) contained approximately the same number of bacteria per cubic centimeter and was from the same dairy, so it is probably fair to compare the results. After one-half hour's heating a much greater reduction was observed where the milk was heated at $60^{\circ} \mathrm{C} .\left(140^{\circ} \mathrm{F}\right.$.). At the end of one hour's heating the bacterial content of the milk were more nearly alike and continued to show a gradual reduction throughout the three hours of heating. The final examination showed that the bacterial content was approxinately the same in all the samples of milk. The bacterial reductions are shown better by the curves in figure 1 . It is evident that long heating $67796^{\circ}-$ Bull. $161-13-3$ 
at $54.4^{\circ} \mathrm{C}\left(130^{\circ} \mathrm{F}.\right)$ and $57.2^{\circ} \mathrm{C} .\left(135^{\circ} \mathrm{F}\right.$.) is of more value than at $60^{\circ} \mathrm{C}$. $\left(140^{\circ} \mathrm{F}\right.$.), as shown by curves $\mathrm{A}, \mathrm{B}$, and $\mathrm{C}$, respectively. From a comparison of curves $\mathrm{A}$ and $\mathrm{C}$ it seems that one and a half hours' heating at $54.4^{\circ} \mathrm{C} .\left(130^{\circ} \mathrm{F}\right.$.) will produce as great a bacterial reduction as one-half hour's heating at $60^{\circ} \mathrm{C} .\left(140^{\circ} \mathrm{F}\right.$.). It must not be assumed, however, that one and one-half hours' heating at $54.4^{\circ} \mathrm{C}$. $\left(130^{\circ} \mathrm{F}\right.$.) will destroy pathogenic organisms as surely as will onehalf hour's heating at $60^{\circ} \mathrm{C}$. $\left(140^{\circ} \mathrm{F}\right.$.). That point can only be determined by experiment.

TABLE 6.-Bacterial reduction during pasteurization for 3 hours at $54.4^{\circ} \mathrm{C} .\left(130^{\circ} \mathrm{F}.\right)$, $57.2^{\circ} \mathrm{C} .\left(135^{\circ} \mathrm{F}.\right)$, and $60^{\circ} \mathrm{C} .\left(140^{\circ} \mathrm{F}.\right)$.

\begin{tabular}{|c|c|c|c|c|c|c|c|}
\hline \multirow{2}{*}{$\begin{array}{c}\text { Temperature } \\
\text { of } \\
\text { pasteuriza- } \\
\text { tion. }\end{array}$} & \multirow{2}{*}{$\begin{array}{l}\text { Bacteria per } \\
\text { cubic centi- } \\
\text { meter in } \\
\text { raw milk. }\end{array}$} & \multicolumn{6}{|c|}{ Bacteria per cubic centimeter in milk pasteurized for- } \\
\hline & & $\frac{1}{2}$ hour. & 1 hour. & $1 \frac{1}{2}$ hours. & 2 hours. & $2 \frac{1}{2}$ hours. & 3 hours. \\
\hline${ }^{\circ} C .{ }^{\circ} \mathrm{F}$. & & & & & & & \\
\hline 54.4130 & $2,530,000$ & 75,000 & 27,600 & 19,400 & 13,200 & 12,300 & 9,200 \\
\hline $60.0 \quad 140$ & $2,330,000$ & 20,800 & 19,400 & 14,100 & 12,400 & 10,300 & 8,700 \\
\hline
\end{tabular}

SIX HOURS' PASTEURIZATION.

A similar experiment was made, using a six hours' period of heating at $62.8^{\circ} \mathrm{C} .\left(145^{\circ} \mathrm{F}\right.$.). In order to meet extreme conditions where the effect of long heating might show, a milk containing $27,000,000$ bacteria per cubic centimeter was selected. Plates were made every half hour during the period of heating. Table 7 shows the results.

TABLE 7.-Bacterial reductions during pasteurization for 6 hours at $62.8^{\circ} \mathrm{C} .\left(145^{\circ} \mathrm{F}\right.$.)

\begin{tabular}{|r|r|r|r|}
\hline $\begin{array}{c}\text { Length of } \\
\text { pasteur- } \\
\text { ization } \\
\text { (hours). }\end{array}$ & $\begin{array}{c}\text { Bacteria per } \\
\text { cubic centi- } \\
\text { meter. }\end{array}$ & $\begin{array}{c}\text { Length of } \\
\text { pasteur- } \\
\text { ization } \\
\text { (hours). }\end{array}$ & $\begin{array}{c}\text { Bacteria per } \\
\text { cubic centi- } \\
\text { meter. }\end{array}$ \\
\hline Raw & $27,000,000$ & 31 & 32,900 \\
$\frac{1}{2}$ & 46,000 \\
11 & 46,000 & 4 & 31,200 \\
$1 \frac{1}{2}$ & 45,000 & $4 \frac{1}{2}$ & 44,000 \\
2 & 65,000 & 51 & 35,700 \\
2 & 62,000 & 6 & 34,000 \\
3 & 54,000 & & \\
\hline
\end{tabular}

It may be seen that there was little difference in the bacterial reduction produced by a half hour's heating and by six hours' heating. There were numerous variations in the numbers of bacteria as determined, but they were within the experimental error, as the flask of heated milk could not be thoroughly shaken. In this experiment the groups of bacteria which withstood the heating were determined. The plating was done on infusion agar plates, which were incubated at 
$30^{\circ} \mathrm{C}$. $\left(86^{\circ} \mathrm{F}\right.$.) for six days. The plates were counted and then each colony picked from a plate and inoculated into litmus milk tubes. After 14 days' incubation the milk cultures were examined and as - $a$ result of the reactions shown the bacteria picked from the plates were divided into five groups, the acid forming and coagulating, acidforming, inert, alkali-forming, and peptonizing groups. The value of this method of determining bacterial groups will be discussed later in this paper. Figure 2 shows the relations of the groups after heating one-half hour, three hours, and six hours. The acid-coagulating and simple acid-forming groups composed the largest portion of the bacteria after a half hour's heating and the same after six hours' pasteurization. It may be seen, however, that the percentage of the acid-coagulating group was reduced by the heating for six hours. It seems probable that the heating weakened the activity of the acidforming bacteria so that in the litmus milk tubes not enough acid was produced to coagulate the milk in the 14 days' incubation period. That would result in a lowering of the percent-

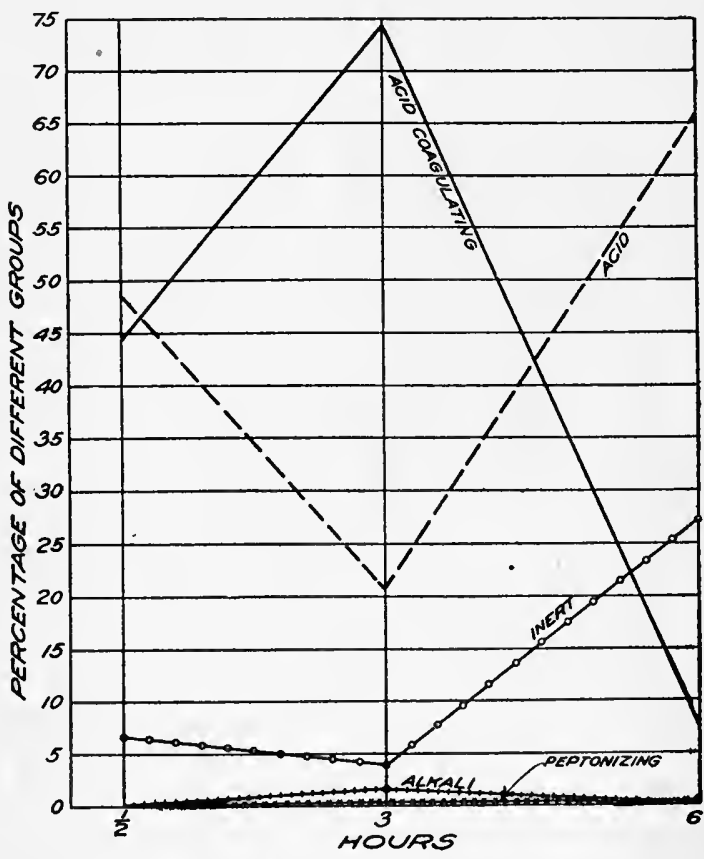

Fı. 2.-Bacterial reduction during pasteurization for six hours at $62.8^{\circ} \mathrm{C} .\left(145^{\circ} \mathrm{F}\right.$. $)$. I'lotted after one-half, three, and six hours. age of the acid-coagulating group, while increasing at the same time the simple acid-forming group. The percentage of the alkali and peptonizing groups was extremely low throughout the experiment. In figure 3 the group percentages have been plotted at every half hour's sampling and gives a more complete picture of the changes in the bacterial groups. The changes in the group percentages between three and one-half and four hours is undoubtedly due to the errors in sampling and inaccuracy of the method of the bacterial group differentiation. 


\section{EFFECT OF SUDDEN COOLING ON THE BACTERIA IN PASTEURIZED MILK.}

The sudden cooling of the hot milk after pasteurization has been considered by many to be an essential part of the process. It was believed that the sudden change from hot to cold aided in the destruc-

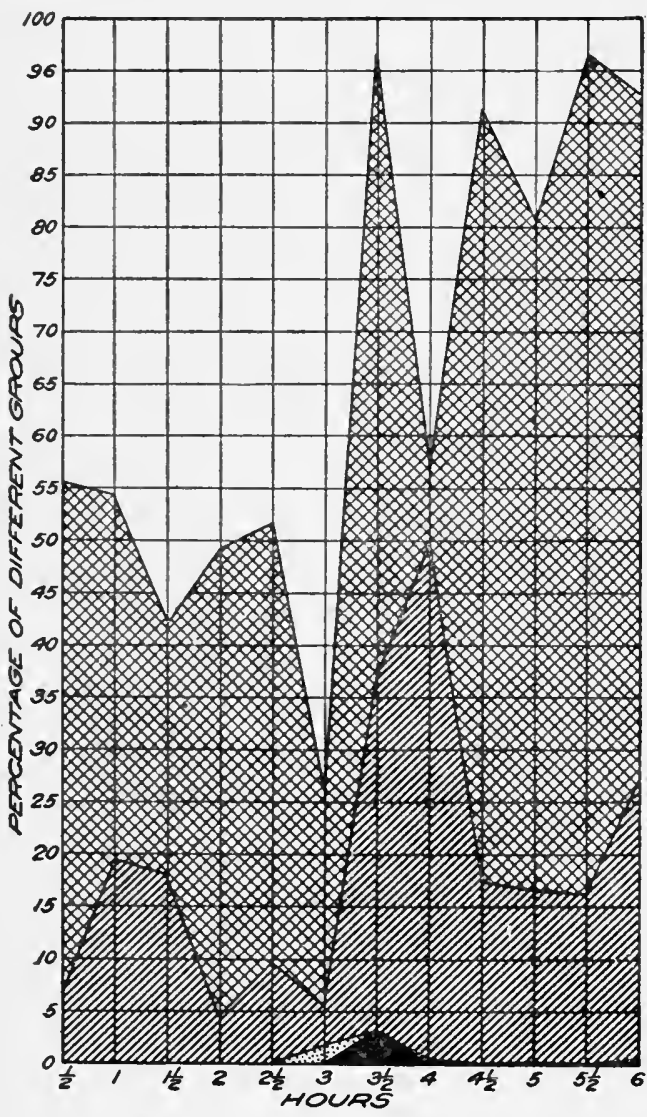
tion of the bacteria. In the recent developments of the process of pasteurization, however, this opinion lost ground, although at the present time there are those who still believe in its value. In order to throw light on this point a few experinents were made under laboratory conditions. Samples of milk were pasteurized in sterile flasks, then cooled by running through a sterile copper coil surrounded by brine into another sterile flask. Table 8 shows the results of the experiments. Two samples of nilk were pasteurized at $62.8^{\circ} \mathrm{C} .\left(145^{\circ} \mathrm{F}\right.$.) for 30 minutes, then cooled in 15 seconds to from $1.7^{\circ}$ $3.9^{\circ}$ C. $\left(35^{\circ}-39^{\circ}\right.$ F. $)$.

FIG. 3.-Bacterial reduction during pasteurization for six hours at The experiment was re$62.8^{\circ} \mathrm{C}$. $\left(145^{\circ} \mathrm{F}\right.$.). Plotted every half hour.

of 30 minutes' heating at $71.1^{\circ} \mathrm{C} .\left(160^{\circ} \mathrm{F}\right.$.). The bacterial content of the milk before and after cooling was approximately the same, the differences always being within the limits of experimental error. It is evident from the results shown in the table that sudden cooling is of no value in causing a destruction of bacteria, at least not at the temperatures used in the experiments. 
TABLE 8.-Effect of sudden cooling on the bacterial content of pasteurized mill.

\begin{tabular}{|c|c|c|c|c|c|c|c|}
\hline \multirow[b]{2}{*}{$\begin{array}{l}\text { Sample } \\
\text { No. }\end{array}$} & \multirow{2}{*}{$\begin{array}{c}\text { Bacteria } \\
\text { per cubic } \\
\text { centimeter } \\
\text { ln raw } \\
\text { unilk. }\end{array}$} & \multicolumn{2}{|c|}{$\begin{array}{l}\text { Pasteurized at } 62.8^{\circ} \mathrm{C} \text {. } \\
\left(145^{\circ} \mathrm{F} .\right) 30 \text { minutes. }\end{array}$} & \multirow[b]{2}{*}{$\begin{array}{l}\text { Sample } \\
\text { No. }\end{array}$} & \multirow{2}{*}{$\begin{array}{l}\text { Bacteria per } \\
\text { cubic conti- } \\
\text { meter in raw } \\
\text { mllk. }\end{array}$} & \multicolumn{2}{|c|}{$\begin{array}{l}\text { Pasteurized at } 71.1^{\circ} \mathrm{C} \text {. } \\
\left(160^{\circ} \mathrm{F} .\right) 30 \text { minutes. }\end{array}$} \\
\hline & & $\begin{array}{c}\text { Bacteria } \\
\text { per cuble } \\
\text { centimeter } \\
\text { in nilk } \\
\text { not cooled. }\end{array}$ & $\begin{array}{l}\text { Bacteria } \\
\text { per eubic } \\
\text { centimeter } \\
\text { in cooled } \\
\text { milk. }\end{array}$ & & & $\begin{array}{l}\text { Bacteria } \\
\text { per cubic } \\
\text { centimeter } \\
\text { in milk } \\
\text { not cooled. }\end{array}$ & $\begin{array}{l}\text { Bacteria } \\
\text { per cubic } \\
\text { centimeter } \\
\text { in cooled } \\
\text { nilk. }\end{array}$ \\
\hline $\begin{array}{l}1 \\
2\end{array}$ & $\begin{array}{l}186,000 \\
233,000\end{array}$ & $\begin{array}{l}8,600 \\
1,470\end{array}$ & $\begin{array}{r}8,500 \\
2,160\end{array}$ & $\begin{array}{l}3 \\
4\end{array}$ & $\begin{array}{r}400,000 \\
1,350,000\end{array}$ & $\begin{array}{l}1,880 \\
1,750\end{array}$ & $\begin{array}{l}1,950 \\
1,700\end{array}$ \\
\hline
\end{tabular}

The value of sudden cooling then, lies in the fact that milk after pasteurization is not allowed to cool slowly through temperatures below $37.8^{\circ} \mathrm{C}$. $\left(100^{\circ} \mathrm{F}\right.$.) where a rapid development of bacteria might occur.

\section{GROUPS OF BACTERIA WHICH SURVIVE PASTEURIZATION.}

The most important feature of this investigation has been the determination of the various groups of bacteria which survive the process of pasteurization. These bacteria form the basis of the bacterial growth in pasteurized milk.

\section{GRADES OF MILK STUDIED.}

Since the bacterial groups in various grades of milk vary with the quality of the milk, it was decided to examine three grades-one of poor quality, one of fair quality, and one of good quality. The bacterial content of each of the samples of the three grades has been averaged as shown in Table 9. With poor milk designated grade A, the average of 20 samples showed a bacterial content of $32,950,000$ per cubic centimeter. An average of 24 samples of grade B showed $3,451,000$ per cubic centimeter, while the average bacterial count of 12 samples of grade C nilk showed 24,700 per cubic centimeter.

TABLE 9.-Grades of milk sturlied.

\begin{tabular}{|c|c|c|}
\hline cirarle. & $\begin{array}{l}\text { Arerage } \\
\text { number of } \\
\text { bacteria } \\
\text { per cubic } \\
\text { eentimeter. }\end{array}$ & $\begin{array}{l}\text { Number } \\
\text { of } \\
\text { samples } \\
\text { averageet. }\end{array}$ \\
\hline 犃 & $\begin{array}{r}32,950,0000 \\
3,451,0100 \\
24,700\end{array}$ & $\begin{array}{l}20 \\
24 \\
12\end{array}$ \\
\hline
\end{tabular}

METHOHS.

In the determination of the bacterial groups a methorl was empleyed which may be designated as the milk-tube method. This method, as described earlier in this paper, consists in picking off each colony on the plate and inoculating it into litmus milk tubes. The milk tubes 
were incubated for 14 days at $30^{\circ} \mathrm{C}$. $\left(86^{\circ} \mathrm{F}\right.$.), and the bacteria from the plate were then divided into groups according to the reactions which they produced in the litmus milk tubes. By using this method it was possible to divide the bacteria developing on a plate into five groups, namely, the acid-forming and coagulating, the acid-forming, the inert which produce no change in milk, the alkali-forming, and the peptonizing groups. The acid-coagulating and the acid-forming groups are not necessarily composed of distinct organisms, although the acid-coagulating group probably included organisms which always coagulate milk, and in the acid group there are undoubtedly bacteria which never coagulate milk. The bacteria were divided by the reaction in litmus milk after incubation for 14 days at $30^{\circ} \mathrm{C}$. $\left(86^{\circ} \mathrm{F}.\right)$. It is impossible by the ordinary method of plating on litmus lactose gelatin to separate the alkali-forming bacteria from those which are inert on gelatin on account of the fact that colonies of alkali-forming bacteria on litmus lactose gelatin plates do not form enough alkali to produce a change of the litmus. The alkali and inert groups must then be classed together and also include acid-forming bacteria which do not produce enough acid to give a red coloration on the plate.

In order to show the value of the tube method a comparison with the plate method was made. Four different samples of milk were used, a portion of each being heated to $60^{\circ} \mathrm{C}$. $\left(140^{\circ} \mathrm{F}\right.$.) and also $65.6^{\circ} \mathrm{C}$. $\left(150^{\circ} \mathrm{F}\right.$.). The pasteurized milk was then plated on litmus lactose gelatin plates which were incubated at $18^{\circ} \mathrm{C} .\left(64.4^{\circ} \mathrm{F}\right.$.) for six days. A differential count was then made of the acid-forming, alkali or inert, and the peptonizing colonies. After counting, the colonies were picked off and inoculated into litmus milk in order to complete the milk-tube method. The results of the experiments are shown in Table 10. It may be plainly seen that the plate method was very inaccurate. The percentage of the acid group of bacteria was always increased by the milk-tube method of differentiation, and the alkali or inert groups were decreased.

TABLE 10.-Comparison of the milk-tube and plate methods for the determination of the bacterial groups in milk.

\begin{tabular}{|c|c|c|c|c|c|c|c|}
\hline \multirow{2}{*}{$\underset{\substack{\text { Sample } \\
\text { No. }}}{ }$} & \multirow{2}{*}{$\begin{array}{l}\text { Temperature } \\
\text { of heating. }\end{array}$} & \multicolumn{2}{|c|}{ Acid group. } & \multicolumn{2}{|c|}{$\begin{array}{l}\text { Alkali or inert } \\
\text { group. }\end{array}$} & \multicolumn{2}{|c|}{ Peptonizing group. } \\
\hline & & $\begin{array}{l}\text { Milk- } \\
\text { tube } \\
\text { method. }\end{array}$ & $\begin{array}{l}\text { Plate } \\
\text { method. }\end{array}$ & $\begin{array}{c}\text { Milk- } \\
\text { tube } \\
\text { method. }\end{array}$ & $\begin{array}{c}\text { Plate } \\
\text { method. }\end{array}$ & $\begin{array}{c}\text { Milk- } \\
\text { tube } \\
\text { method. }\end{array}$ & $\begin{array}{c}\text { Plate } \\
\text { method. }\end{array}$ \\
\hline $\begin{array}{l}1 \\
1 \\
2 \\
2 \\
3 \\
3 \\
4 \\
4\end{array}$ & $\begin{array}{ll}{ }^{\circ} C . & { }^{\circ} F . \\
60.0 & 140 \\
65.6 & 150 \\
60.0 & 140 \\
65.6 & 150 \\
60.0 & 140 \\
65.6 & 150 \\
60.0 & 140 \\
65.6 & 150\end{array}$ & $\begin{array}{c}\text { Per cent. } \\
73.21 \\
75.68 \\
62.29 \\
77.89 \\
58.39 \\
94.36 \\
92.17 \\
90.64\end{array}$ & $\begin{array}{c}\text { Pcr cent. } \\
58.73 \\
56.96 \\
25.15 \\
12.93 \\
34.35 \\
45.68 \\
56.37 \\
49.41\end{array}$ & $\begin{array}{c}\text { Percent. } \\
16.07 \\
11.01 \\
35.16 \\
18.95 \\
32.83 \\
4.83 \\
7.25 \\
7.20\end{array}$ & $\begin{array}{c}\text { Pcrcent. } \\
\mathbf{4 0 . 2 1} \\
41.79 \\
72.32 \\
86.20 \\
58.77 \\
52.15 \\
42.64 \\
50.58\end{array}$ & $\begin{array}{c}\text { Per cent. } \\
10.71 \\
13.30 \\
2.54 \\
3.15 \\
8.75 \\
.80 \\
.56 \\
2.15\end{array}$ & $\begin{array}{c}\text { Per cent. } \\
1.05 \\
1.24 \\
2.52 \\
.86 \\
6.87 \\
2.15 \\
.98\end{array}$ \\
\hline
\end{tabular}


Usually the peptonizing group of bacteria was also increased. The differences in the differentiation of the bacterial groups is shown graphically in figure 4 . The bacterial flora of four samples of milk pasteurized at $60^{\circ} \mathrm{C}$. $\left(140^{\circ} \mathrm{F}\right.$.) as shown by averages and determined by the plate method consisted of 43.65 per cent of the acid group, 53.48 per cent of alkali or inert group, and 2.85 per cent of the peptonizing group. When determined by the milk-tube method the group percentages were changed to 71.51 per cent of the acid group, 22.83 per cent of the alkali or inert group, and 5.64 per cent of the peptonizing group.

When milk was pasteurized at $65.6^{\circ} \mathrm{C} .\left(150^{\circ}\right.$ F.) there were marked differences in the bacterial flora when determined by the two methods (see fig. 4). The results from four samples were averaged. As determined by the plate method the bacterial flora consisted of 41.24 per cent of the acid group, 57.68 per cent of the alkali or inert group, and 1.06 per cent of the peptonizing grou . When determined by the milk-tube method the percentages were changed to 84.64 per cent of the acid group,

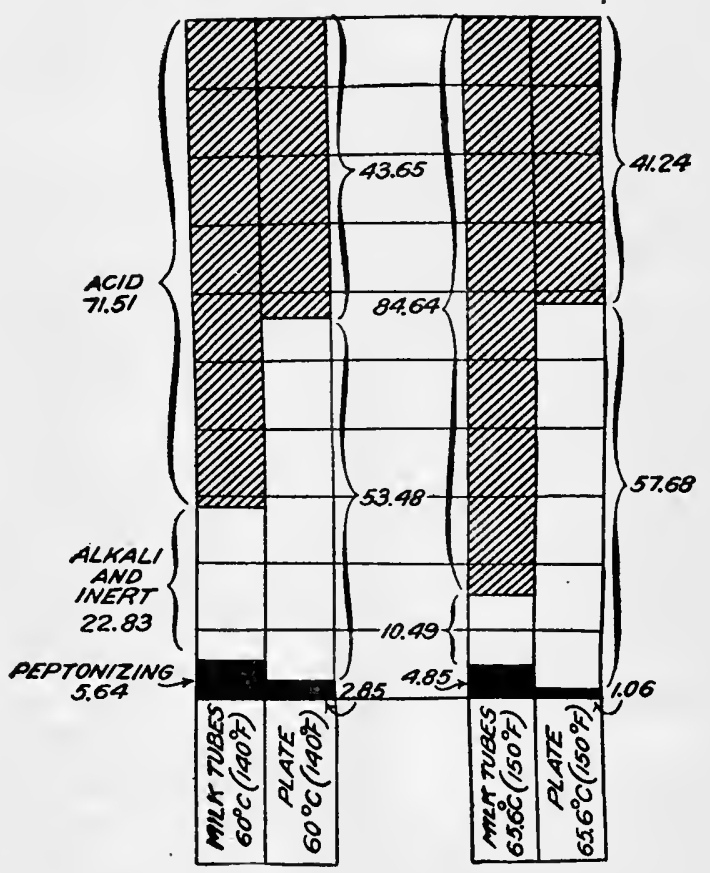

Fig. 4.-Comparison of the milk-tube and plate method for the determination of the bacterial groups in milk.

10.49 per cent of the alkali or inert group, and 4.85 per cent of the peptonizing group. It is evident from these experiments that the milktube method was much superior to the litmus lactose gelatin plate method of differentiation. Its advantages may be summarized as follows:

1. The milk-tube method is more accurate than the plate method for the differentiation of bacteria into groups.

2. It is possible by this method to separate the alkali-forming group of bacteria from the inert group, which is not possible on litmus lactose gelatin plates.

3. The activity of the bacteria in the various groups can to some extent be determined by their ability to produce changes in litmus milk after various lengths of incubation. 
THE BACTERIAL GROUPS IN GRADE A MILK BEFORE AND AFTER PASTEURIZATION FOR 30 MINUTES AT $62.8^{\circ}$ C. $\left(145^{\circ}\right.$ F.).

Throughout the study of the bacterial groups in raw and pasteurized milk the milk-tube method of differentiation has been used. The plating was on infusion agar, which was incubated for six days at $30^{\circ} \mathrm{C} .\left(86^{\circ} \mathrm{F}.\right)$. The milk used in the first experiments was of poor quality and constitutes grade A milk. Pasteurization was per-

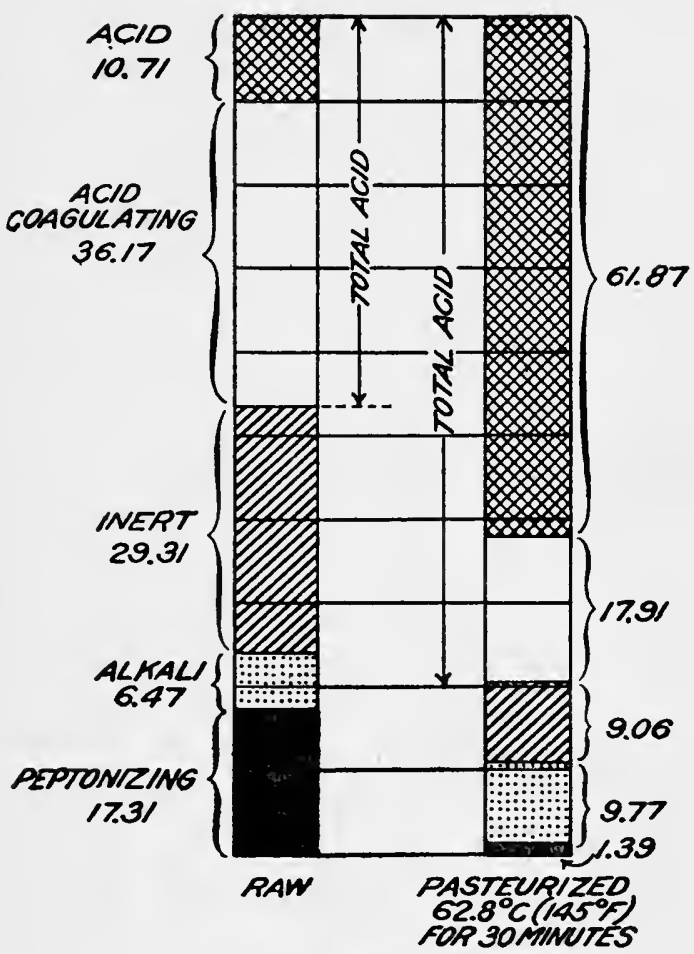

FIG. 5.-Bacterial groups of grade A milk before and after pasteurization for 30 minutes at $62.8^{\circ} \mathrm{C}$. $\left(145^{\circ} \mathrm{F}\right.$.). formed in sterile flasks and heated in a water bath for 30 minutes at $62.8^{\circ} \mathrm{C} .\left(145^{\circ} \mathrm{F}\right.$.). The percentage of the different bacterial groups was determined before and after pasteurization of the milk. In order to show the results in the most simple manner the group percentages of 10 samples of raw milk and 12 of pasteurized milk have been averaged and are shown graphically in figure 5. The average of the.total acid group in raw milk was 46.88 per cent of the total bacteria. After pasteurization the percentage was increased to $79.7 \mathrm{~s}$ per cent. The acid coagulating group was decreased from

36.17 per cent to 17.91 per cent. The inert group was also decreased and the alkali group slightly increased, from 6.47 per cent to 9.77 per cent, which was due to the averaging of one sample of pasteurized milk which was exceptionally high in the percentage of the alkali formers. The peptonizing group was decreased from 17.31 per cent in the raw milk to 1.39 per cent in the pasteurized milk. These results are most striking in so far that they are contrary to the most generally accepted ideas of the effect of pasteurization on the bacterial flora of milk. 
THE BACTERIAL GROUPS IN GRADE A MILK BEFORE AND AFTER PASTEURIZATION FOR 30 MINUTES AT $71.1^{\circ}$ C. ( $\left(160^{\circ}\right.$ F.).

A second set of experiments was made, using grade A milk which was pasteurized at $71.1^{\circ} \mathrm{C}$. $\left(160^{\circ} \mathrm{F}\right.$.) for 30 minutes and examined in the same manner as before. The averaged results of five samples of raw and six samples of pasteurized milk are shown in figure 6. The changes in the bacterial groups were about the same as at $62.8^{\circ}$ C. $\left(145^{\circ} \mathrm{F}.\right)$. While the percentage of the total acid group was higher than in the milk pasteurized at the lower temperatures, it will be seen that the percentage of the acid-coagulating group was smaller. The acid group was made up largely of slow acid-forming organisms, as will be shown later. The alkali group was reduced and the peptonizing group reduced from 16.26 per cent in the raw to 0.53 per cent in the pasteurized milk.

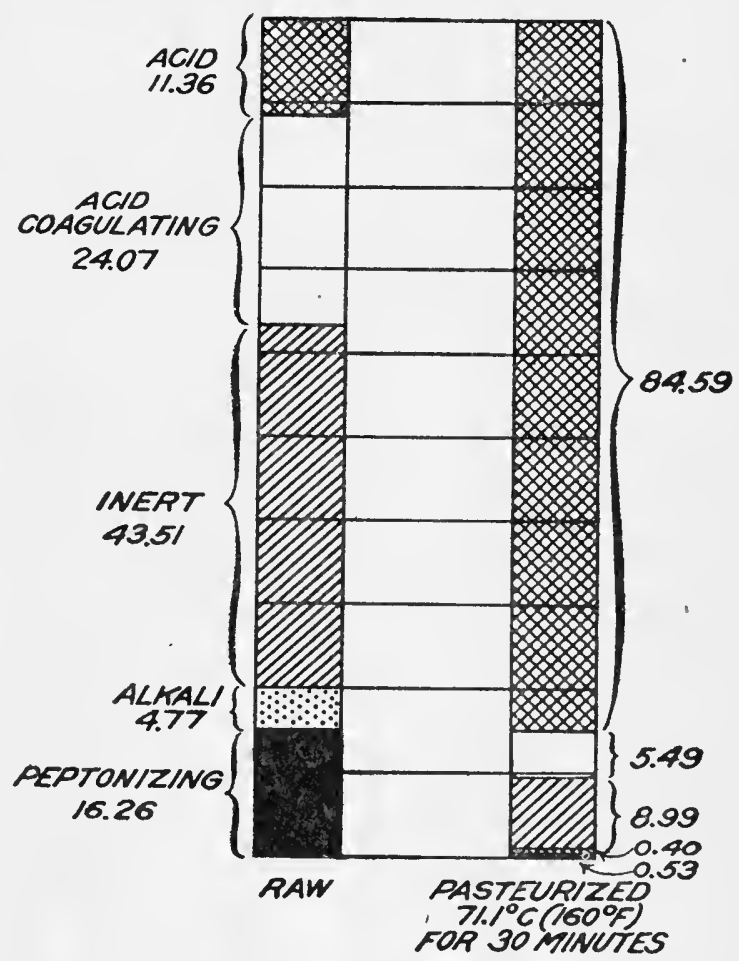

F1G. 6.-Bacterial groups in grade $\Lambda$ milk before and after pasteuriza. tion for 30 minutes at $71.1^{\circ} \mathrm{C} .\left(160^{\circ} \mathrm{F}\right.$.).

THE BACTERIAL GROUPS IN GRADE B MILK BEFORE AND AFTER PASTEURIZATION FOR 30 MINUTES AT $62.8^{\circ}$ C. ( $145^{\circ}$ F.).

The same experiments were repeated, pasteurizing a better quality of milk, grade $\mathrm{B}$, at $62.8^{\circ} \mathrm{C}$. $\left(145^{\circ} \mathrm{F}\right.$.). The averaged results of 17 samples of raw and 20 samples of pasteurized milk are shown in figure 7. The total acid group was increased from 22.72 per cent in the raw to 66.76 per cent in the pasteurized milk. It will be noticed that the acid-coagulating group was increased from 12.98 per cent to 31.89 per cent in the pasteurized milk. The alkali and peptonizing groups were reduced from 19.66 per cent to 5.63 per cent and from 14.10 to 3.59 per cent, respectively. 
THE BACTERIAL GROUPS IN GRADE C MLK BEFORE AND AFTER PASTEURIZATION FOR 30 MINUTES AT $62.8^{\circ}$ C. $\left(145^{\circ}\right.$ F.).

A third grade of milk of good quality, grade C, was studied in the same manner as the other grades. The percentage of the various bacterial groups changed in a similar manner as in the other experiments. The milk was pasteurized for 30 minutes at $62.8^{\circ} \mathrm{C}$. $\left(145^{\circ} \mathrm{F}\right.$.). Figure 8 shows the averaged results. It may be seen that again the total acid group was increased in percentage from 40.70 per cent to 73.10 per cent of the total bacteria. The acid-

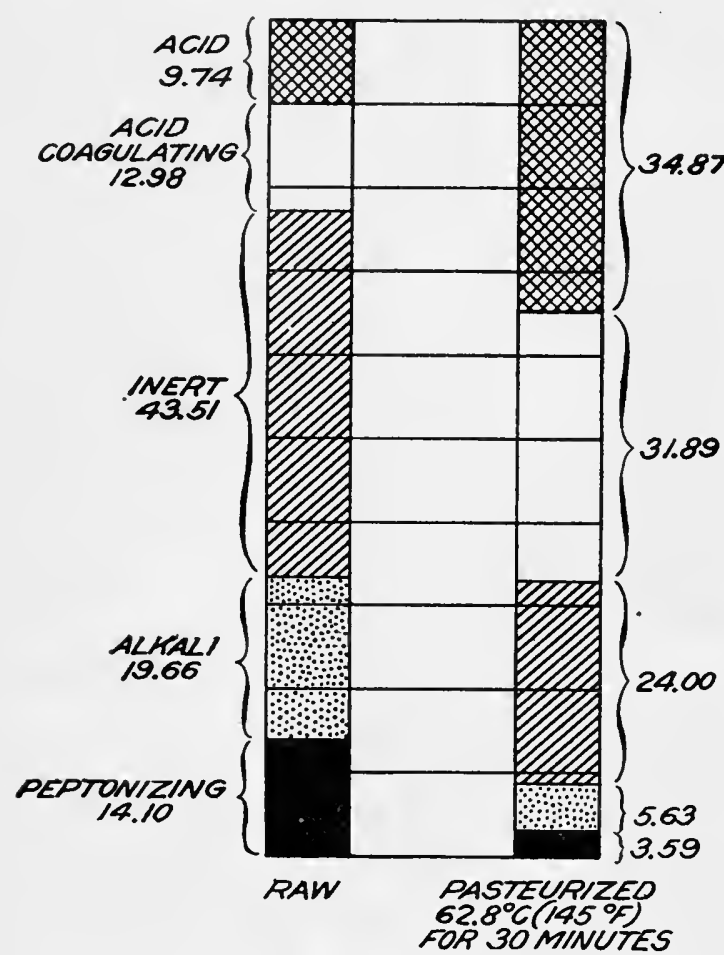

FIG. 7.-Bacterial groups in grade $\mathrm{B}$ milk before and after pasteurization for 30 minutes at $62.8^{\circ} \mathrm{C} .\left(145^{\circ} \mathrm{F}\right.$.). coagulating group, however, decreased in percentage from 33.85 per cent to $11.85 \mathrm{per}$ cent. All the other groups were decreased in their percentage by pasteurization. These results show that instead of the acid-forming bacteria being destroyed by pasteurization they were actually increased in their percentage of the total bacteria surviving the process. This does not mean that there were greater numbers of acid-forming bacteria after pasteurization but merely that a greater percentage of the bacteria in pasteurized milk were of the acid-forming group than in the milk before heating. The percentage of the other groups was lowered by pasteurization. This is of particular interest in the case of the peptonizing group, which has been believed to constitute the majority of the bacteria which survive the heating process. It must be remembered that these results apply for the most part to milk pasteurized at $62.8^{\circ} \mathrm{C}$. $\left(145^{\circ} \mathrm{F}\right.$.), although they hold for the few samples studied which were heated at $71.1^{\circ} \mathrm{C} .\left(160^{\circ} \mathrm{F}\right.$.). So far as the practical side is concerned, only the results at $62.8^{\circ} \mathrm{C}$. $\left(140^{\circ} \mathrm{F}\right.$.) are of value, for the higher temperatures are seldom used in commercial work. 
THE BACTERIAL GROUPS IN MILK PASTEURIZED AT HIGH

TEMPERATURES.

In order to determine the bacteria which survive pasteurization at high temperatures, the bacterial groups were determined by the milk-tube method in seven samples of milk. Two samples were pasteurized at $76.7^{\circ} \mathrm{C}$. $\left(170^{\circ} \mathrm{F}\right.$.), three at $82.2^{\circ} \mathrm{C} .\left(180^{\circ} \mathrm{F}\right.$.), one at $87.8^{\circ} \mathrm{C}$. $\left(190^{\circ} \mathrm{F}\right.$.), and two at $93.3^{\circ} \mathrm{C} .\left(200^{\circ} \mathrm{F}\right.$.). All were heated in sterile flasks and the temperatures held for 30 minutes. The percentages of the bacterial groups have been averaged at each temperature and are shown in figure 9 . It will be seen that even at $76.7^{\circ}$ C. $\left(170^{\circ}\right.$ F.) a large percentage of the acidforming group was found, the percentage of the total acid-forming group, including both the acid-coagulating and the simple acidforming group, being 80.91 per cent. The bacteria of this group, however, produced acid very slowly, which differentiates them from those which survive at lower temperatures. An increase in the percentage of the peptonizing group over that at the lower temperatures is noticeable. Theaverage percentage of the pepton-

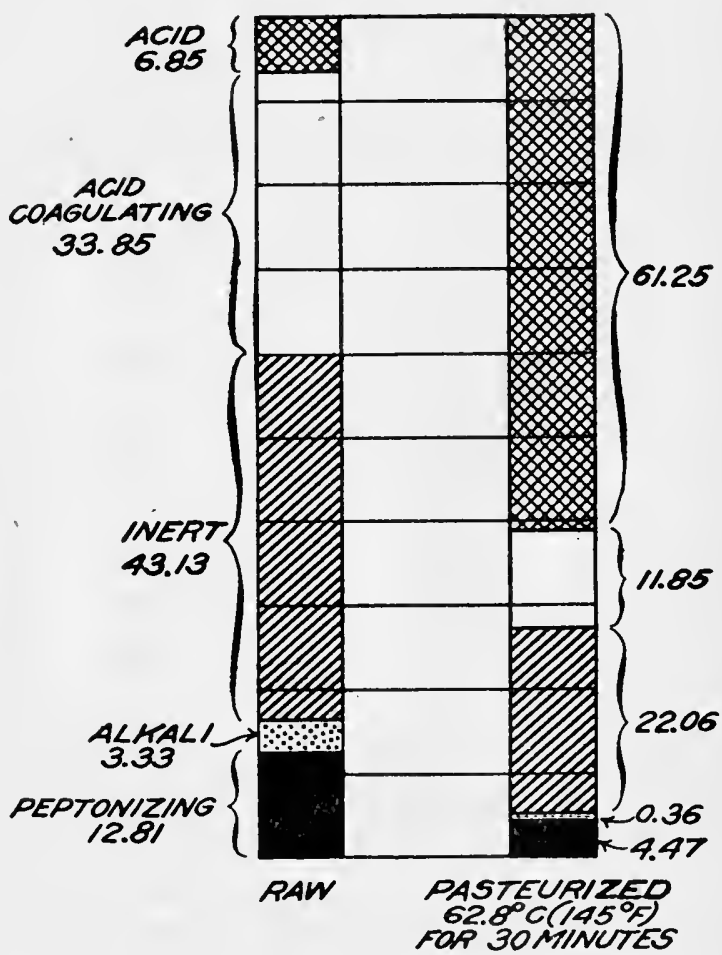

Fia. 8.-Bacterial groups in grade $\mathrm{C}$ milk before and after pasteurization for 30 minutes at $62.8^{\circ} \mathrm{C} .\left(145^{\circ} \mathrm{F}\right.$.).

izing group at $62.8^{\circ} \mathrm{C}$. $\left(145^{\circ} \mathrm{F}\right.$.) ranged from 1.39 per cent to 4.47 per cent in three grades of milk. At $71.1^{\circ} \mathrm{C} .\left(160^{\circ} \mathrm{F}\right.$.) the percentage was 0.53 per eent, while at $76.7^{\circ} \mathrm{C}$. $\left(170^{\circ} \mathrm{F}\right.$.) it was increased to 7.25 per cent. The inerease is of course produced by the greater destruction of the other groups. At $82.2^{\circ} \mathrm{C} .\left(180^{\circ} \mathrm{F}\right.$.) a distinct change took place in percentage of the groups which survived the heating. The acid group was reduced greatly, while the peptonizing group was increased to $68: 12$ per cent of the total bacteria. The alkali group eomprised 16.08 per cent of the bacteria, which is evirlently a very high avernge. If a large number of samples had been studied, the average percentage of the 
group would have probably been very low, since at $71.1^{\circ} \mathrm{C} .\left(160^{\circ} \mathrm{F}\right.$.) and $76.7^{\circ} \mathrm{C}$. $\left(170^{\circ} \mathrm{F}\right.$.) only a very small percentage survived. The bacterial groups at the higher temperatures were similar to those at $82.2^{\circ} \mathrm{C}$. $\left(180^{\circ} \mathrm{F}\right.$.). The almost total absence of the acid-coagulating group and the low percentage of the acid group, together with the high percentage of the peptonizing group, is very noticeable.

\section{THE ACTIVITY OF BACTERIA OF THE VARIOUS GROUPS ISOLATED FROM RAW AND PASTEURIZED MILK MEASURED BY THEIR ABILITY TO PRODUCE CHANGES IN IITMUS MILK AFTER DIF- FERENT LENGTHS OF INCUBATION.}

The activity of the bacteria found in raw and pasteurized milk is important since acid-forming bacteria which coagulates milk in 48 hours produce a more normal souring in pasteurized milk than the

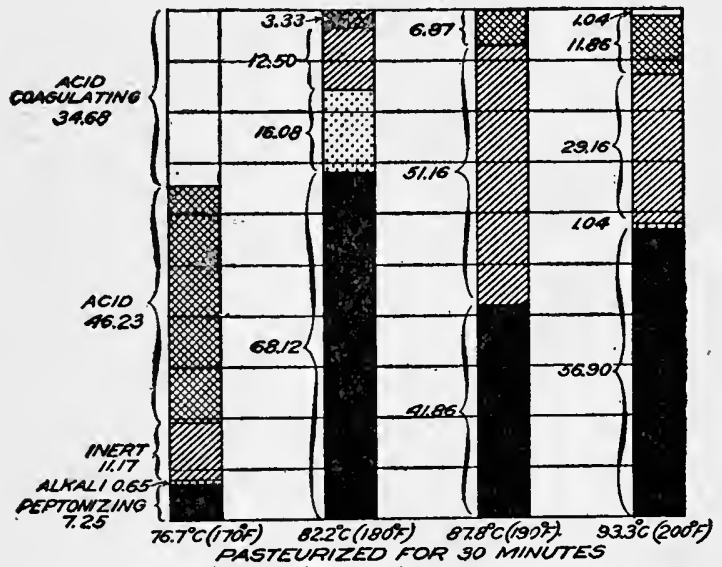

Fig. 9.-Bacterial groups which survive pasteurization for $30 \mathrm{~min}$ utes at $76.7^{\circ} \mathrm{C} .\left(170^{\circ} \mathrm{F}.\right), 82.2^{\circ} \mathrm{C} .\left(180^{\circ} \mathrm{F}.\right), 87.8 \mathrm{C}$. $\left(190^{\circ} \mathrm{F}\right.$.), and $93.3^{\circ} \mathrm{C} .\left(200^{\circ} \mathrm{F}\right.$.). slow acid-producing forms which may be overgrown by the peptonizing bacteria. Organisms of the peptonizing group which cause peptonization rapidly are of far greater importance than those which require long incubation to produce changes in milk. During the determination of the bacterial groups by the milk-tube method the reactions produced by the different cultures of bacteria were recorded after 2, 5, and 14 days' incubation. The length of time required to produce changes in litmus milk served as a measure of the activity of the culture. It then follows that the changes in the group relations as determined by the litmus milk tube reactions gave a general indication of the activity of the bacteria which composed the group.

The activity of bacteria of the various groups isolated from three grades of milk has been studied.

GRADE A MILK BEFORE AND AFTER PASTEURIZATION AT $62.8^{\circ} \mathrm{C}$. $\left(145^{\circ}\right.$ F.) FOR 30 MINUTES.

The results shown in Table 11 indicate the rapidity of the growth of the bacteria of the various groups isolated from milk before and after pasteurization at $62.8^{\circ} \mathrm{C}$. $\left(145^{\circ} \mathrm{F}\right.$.) as measured by their ability to produce a change in litmus milk. As may be noted from the table, 
plates were made of infusion and casein agar and the colonies developing on each medium were picked off and differentiated by the tube method. The group percentages in the table represent the average of a number of samples. In general it may be said that casein agar seemed to favor the growth of the alkali forming and the peptonizing bacteria so that their group percentages were usually higher when determined on that medium. In order to show the results more plainly the averages have been plotted as shown in figure 10. The blocks in the columns represent the bacterial group percentages determined by the tube method after 2,5 , and 14 days' incubation in milk. The column at 2 days, for example, shows the group percentages determined by the reactions of the colonies picked from an infusion agar plate. The percentages were determined by the reactions of the milk tubes after 2 days' incubation at $30^{\circ} \mathrm{C}$. $\left(86^{\circ} \mathrm{F}\right.$.). The tubes were then incubated for 3 days more and the group percentages again determined by the reactions. Ineubation was then continued for 14 days, when the final reactions were recorded. The figure shows that the percentage of the total acid group was greater in raw milk after two days' incubation than in pasteurized. After five

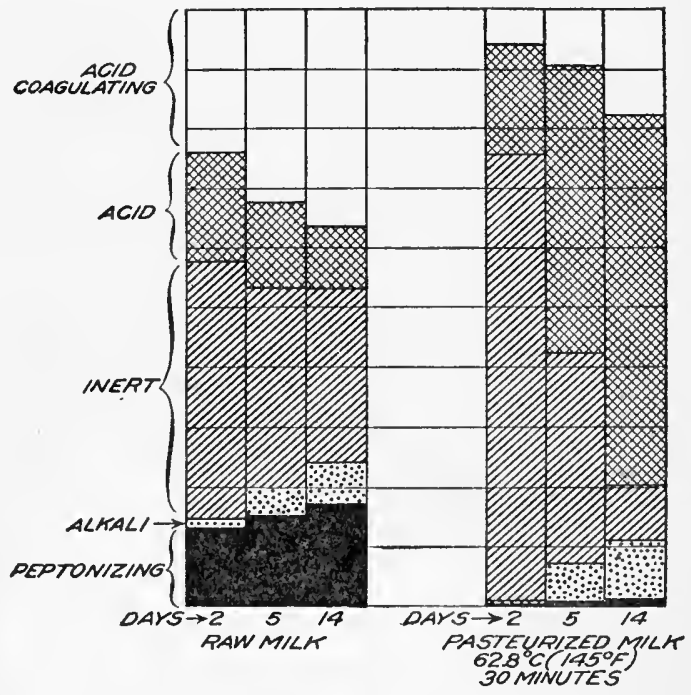

FIG. 10.-Changes in the bacterial group relations in grade $A$ milk when determined by litmus milk reactions after different lengths of incubation. Milk pasteurized at $62.8^{\circ} \mathrm{C}$. $\left(145^{\circ} \mathrm{F}\right.$.) for 30 minutes.

days, however, the total acid group was higher in percentage in pasteurized milk. After 14 days the total acid group in pasteurized milk was much larger. This shows that the bacteria of the acid group in pasteurized milk develop slower, or at least produce acid slower, than those in raw milk. Since the differentiation of the groups was based on the change produced in litmus milk by the bacteria, it may be seen from the figure that as a rule the alkali-forming bacteria did not develop enough alkali to change the color of litmus, which differentiates them as belonging to the alkali group, until the fifth day of incubation. While the figure may seem rather complicated, a careful study clearly shows the difference in the bacterial groups in raw and pasteurized milk based on the rapidity with which they produce changes in litmus milk. 
TABLE 11.-Changes in the bacterial group relations in grade $A$ milk when determined by litmus milk reactions after different lengths of incubation-Milk pasteurized at $62.8^{\circ} \mathrm{C}$. $\left(145^{\circ} \mathrm{F}\right.$.) for 30 minutes.

\begin{tabular}{|c|c|c|c|c|c|c|c|c|c|c|c|c|}
\hline \multirow{3}{*}{ Bacterial groups. } & \multicolumn{6}{|c|}{ Infusion agar plates. } & \multicolumn{6}{|c|}{ Casein agar plates. } \\
\hline & \multicolumn{3}{|c|}{ Raw milk. } & \multicolumn{3}{|c|}{ Pasteurized milk. } & \multicolumn{3}{|c|}{ Raw milk. } & \multicolumn{3}{|c|}{ Pasteurized milk. } \\
\hline & $\stackrel{2}{\text { days. }}$ & $\begin{array}{c}5 \\
\text { days. }\end{array}$ & $\begin{array}{c}14 \\
\text { days. }\end{array}$ & $\stackrel{2}{\text { days. }}$ & $\begin{array}{c}5 \\
\text { days. }\end{array}$ & $\begin{array}{c}14 \\
\text { days. }\end{array}$ & $\stackrel{2}{2}$ days. & $\begin{array}{c}5 \\
\text { days. }\end{array}$ & $\begin{array}{c}14 \\
\text { days. }\end{array}$ & $\underset{2}{2}$ & $\begin{array}{c}5 \\
\text { days. }\end{array}$ & $\begin{array}{c}14 \\
\text { days. }\end{array}$ \\
\hline $\begin{array}{l}\text { Acid coagulating } \\
\text { Acid.............. } \\
\text { Inert............. } \\
\text { Alkali............ } \\
\text { Peptonizing..... }\end{array}$ & $\begin{array}{r}\text { Perct. } \\
24.18 \\
13.08 \\
42.94 \\
1.29 \\
13.47\end{array}$ & $\begin{array}{r}\text { Per ct. } \\
32.72 \\
14.64 \\
33.23 \\
4.02 \\
15.37\end{array}$ & $\begin{array}{r}\text { Pcrct. } \\
36.17 \\
10.71 \\
29.31 \\
6.47 \\
17.31\end{array}$ & $\begin{array}{r}\text { Perct. } \\
6.01 \\
19.01 \\
74.69 \\
.02 \\
.26\end{array}$ & $\begin{array}{r}\text { Perct. } \\
9.52 \\
48.01 \\
35.13 \\
6.55 \\
.77\end{array}$ & $\begin{array}{r}\text { Perct. } \\
17.91 \\
61.87 \\
9.06 \\
9.77 \\
1.39\end{array}$ & $\begin{array}{r}\text { Perct. } \\
7.89 \\
15.13 \\
62.26 \\
.70 \\
13.99\end{array}$ & \begin{tabular}{|} 
Per ct. \\
16.96 \\
14.34 \\
$\mathbf{4 5 . 9 5}$ \\
5.69 \\
17.04
\end{tabular} & $\begin{array}{l}\text { Per ct. } \\
19.51 \\
12.12 \\
32.99 \\
17.58 \\
17.77\end{array}$ & $\begin{array}{r}\text { Perct. } \\
2.42 \\
11.63 \\
85.80 \\
\cdots .12\end{array}$ & $\begin{array}{r}\text { Per ct. } \\
4.34 \\
42.17 \\
49.67 \\
4.17 \\
.62\end{array}$ & $\begin{array}{r}\text { Perct. } \\
15.12 \\
51.95 \\
15.98 \\
15.73 \\
1.20\end{array}$ \\
\hline Total ..... & $99 . \overline{96}$ & 99.98 & 99.97 & 99.99 & 99.99 & 100.00 & 99.97 & 99.98 & 99.97 & 99.97 & 99.97 & 99.98 \\
\hline $\begin{array}{l}\text { Number of sam- } \\
\text { ples averaged.. }\end{array}$ & 10 & 10 & 10 & 12 & 12 & 12 & 7 & 7 & 7 & 10 & 10 & 10 \\
\hline
\end{tabular}

GRADE A MILK BEFORE AND AFTER PASTEURIZATION FOR 30 MINUTES AT $71.1^{\circ}$ C. $\left(160^{\circ}\right.$ F.).

Earlier in this paper it was shown that the percentage of the total acid group was higher in grade A milk pasteurized at $71.1^{\circ} \mathrm{C} .\left(160^{\circ}\right.$ F.) than at $62.8^{\circ} \mathrm{C}$. $\left(145^{\circ} \mathrm{F}\right.$.). It is natural to suppose, then, that milk pasteurized at the higher temperatures would sour more quickly than when heated at the lower temperatures. Such is not the case,

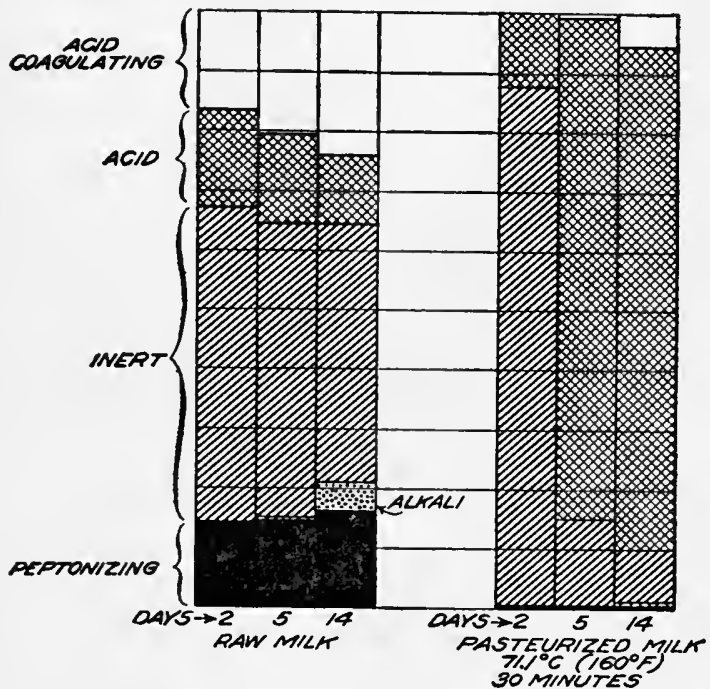

Frg. 11.-Changes in the bacterial group relations in grade $A$ milk when determined by litmus milk reactions after different lengths of incubation. Milk pasteurized at $71.1^{\circ} \mathrm{C}$. $\left(160^{\circ} \mathrm{F}\right.$.) for 30 minutes. however; first, because the total number of bacteria are less in the milk pasteurized at $71.1^{\circ} \mathrm{C}$. $\left(160^{\circ} \mathrm{F}\right.$.), and, second, because the acid group of bacteria is less active. 'This last reason is shown by the changes in the bacterial group relations as determined in litmus milk by different lengths of incubation. Table 12 shows the averaged group percentages determined from infusion and casein agarplates. The results are shown

to better advantage in figure 11. It will be noticed that after two days' incubation only a small percentage of acid-forming bacteria were recorded in the pasteurized milk and none of the acid-coagulat- 
ing group. After five days the acid group was increased greatly, but there was only an extremely small percentage of the acid-coagulating group. Even after 14 days' incubation the reactions showed only a small percentage of the acid-coagulating group. In both raw and pasteurized milk the slow growth of the alkali group is shown by the fact that only a small percentage was found in the raw milk after five days' incubation of the litmus milk tubes, while none was found in the pasteurized milk until after 14 days' incubation.

TABLE 12.-Changes in the bacterial group relations in grade A milk when determined by litmus milk reactions after different lengths of incubation-Milk pasteurized at $71.1^{\circ} \mathrm{C}$. $\left(160^{\circ} \mathrm{F}\right.$.) for 30 minutes.

\begin{tabular}{|c|c|c|c|c|c|c|c|c|c|c|c|c|}
\hline \multirow{3}{*}{$\begin{array}{l}\text { Bacterial } \\
\text { groups. }\end{array}$} & \multicolumn{6}{|c|}{ Infusion agar plates. } & \multicolumn{6}{|c|}{ Casein agar plates. } \\
\hline & \multicolumn{3}{|c|}{ Raw milk. } & \multicolumn{3}{|c|}{ Pasteurized milk. } & \multicolumn{3}{|c|}{ Raw milk. } & \multicolumn{3}{|c|}{ Pasteurized milk. } \\
\hline & $\stackrel{2}{\text { days. }}$ & $\begin{array}{c}5 \\
\text { days. }\end{array}$ & $\begin{array}{l}14 \\
\text { days. }\end{array}$ & days. & $\begin{array}{c}5 \\
\text { days. }\end{array}$ & $\begin{array}{l}14 \\
\text { days. }\end{array}$ & $\stackrel{2}{2}$ & $\begin{array}{c}5 \\
\text { days. }\end{array}$ & $\begin{array}{c}14 \\
\text { days. }\end{array}$ & $\stackrel{2}{2}$ days. & \begin{tabular}{c|}
5 \\
days.
\end{tabular} & $\begin{array}{l}14 \\
\text { days. }\end{array}$ \\
\hline $\begin{array}{l}\text { Acid coagulat- } \\
\text { ing........... } \\
\text { Acid.......... } \\
\text { Inert ............ } \\
\text { Alkali......... } \\
\text { Peptonizing.... }\end{array}$ & \begin{tabular}{l} 
Perct. \\
16.58 \\
16.35 \\
52.95 \\
\hdashline 14.11
\end{tabular} & $\begin{array}{l}\text { Perct. } \\
20.22 \\
14.60 \\
49.51 \\
.89 \\
14.76\end{array}$ & $\begin{array}{r}\text { Perct. } \\
24.07 \\
11.36 \\
43.51 \\
4.77 \\
16.26\end{array}$ & $\begin{array}{l}\text { Perct. } \\
12.03 \\
87.56 \\
.39\end{array}$ & $\begin{array}{r}\text { Perct. } \\
0.17 \\
85.29 \\
14.14 \\
.39\end{array}$ & $\begin{array}{r}\text { Perct. } \\
5.49 \\
84.59 \\
8.99 \\
.40 \\
.53\end{array}$ & $\begin{array}{l}\text { Perct. } \\
12.47 \\
10.65 \\
64.30 \\
.13 \\
12.43\end{array}$ & $\begin{array}{r}\text { Perct. } \\
16.49 \\
6.44 \\
58.85 \\
2.43 \\
15.77\end{array}$ & $\begin{array}{r}\text { Perct. } \\
17.50 \\
7.22 \\
47.28 \\
10.06 \\
17.92\end{array}$ & $\mid \begin{array}{c}\text { Perct. } \\
\cdots 7.67 \\
92.26 \\
.06\end{array}$ & $\mid \begin{array}{c}\text { Perct. } \\
70.10 \\
29.53 \\
.36\end{array}$ & $\begin{array}{r}\text { Perct. } \\
10.88 \\
63.44 \\
24.93 \\
.70\end{array}$ \\
\hline Total.. & 99.99 & 99.98 & 99.97 & 99.98 & 99.99 & 100.00 & 99.98 & 99.98 & 99.98 & 99.99 & 99.99 & $\overline{99.95}$ \\
\hline $\begin{array}{l}\text { Number of sam- } \\
\text { ples averaged. }\end{array}$ & 5 & 5 & 5 & 6 & 6 & 6 & 9 & 9 & 9 & 11 & 11 & 11 \\
\hline
\end{tabular}

GRADE B MLK BEFORE AND AFTER PASTEURIZATION FOR 30 MiNUTES AT $62.8^{\circ}$ C. $\left(145^{\circ}\right.$ F.)

The changes in the bacterial group relations determined by the milk-tube method after various lengths of incubation showed a difference from those in grade A milk. Table 13 shows the arerages of thegroup percentages which are plotted in figure 12. A study of the plot shows that the percentage of the total acid group and the acid - coagulating group itself was greater in the pasteurized milk after the two days' incubation period than in the raw milk. In other words, the activity of the acid-producing organisms which survived

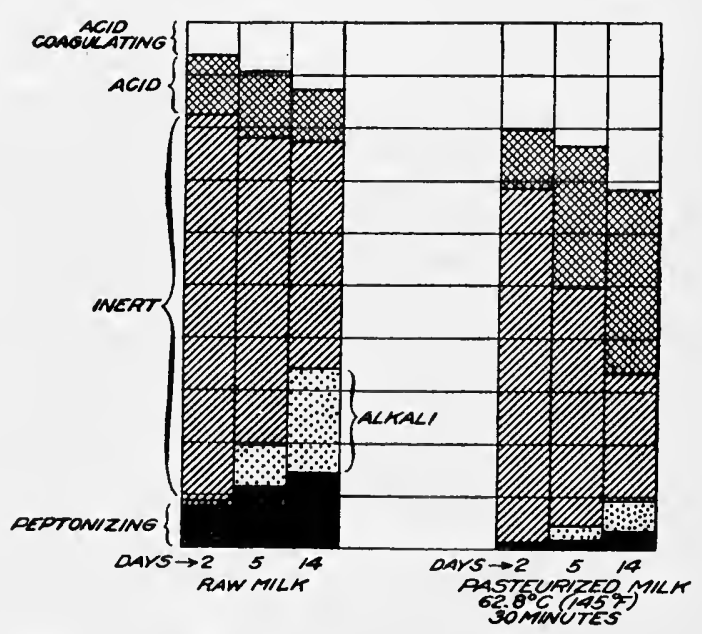

Fig. 12.-Changes in the baeterial group relations in grade B milk when determined by litmus milk reaetions after different lengths of incubation.

the heating was as great as those in raw milk. The reason for the difference in the two grades of milk is not apparent. 
TABLE 13.-Changes in the bacterial group relations in grade $B$ milk when determined by litmus milk reactions after different lengths of incubation-Milk pasteurized at $62.8^{\circ} \mathrm{C}$. $\left(145^{\circ} \mathrm{F}\right.$.) for 30 minutes.

\begin{tabular}{|c|c|c|c|c|c|c|c|c|c|c|c|c|}
\hline \multirow{3}{*}{$\begin{array}{l}\text { Bacterial } \\
\text { groups. }\end{array}$} & \multicolumn{6}{|c|}{ Infusion agar plates. } & \multicolumn{6}{|c|}{ Casein agar plates. } \\
\hline & \multicolumn{3}{|c|}{ Raw milk. } & \multicolumn{3}{|c|}{ Pasteurized milk. } & \multicolumn{3}{|c|}{ Raw milk. } & \multicolumn{3}{|c|}{ Pasteurized milk. } \\
\hline & $\stackrel{2}{2}$ days. & $\begin{array}{c}5 \\
\text { days. }\end{array}$ & $\begin{array}{c}14 \\
\text { days. }\end{array}$ & $\begin{array}{c}2 \\
\text { days. }\end{array}$ & $\begin{array}{c}5 \\
\text { days. }\end{array}$ & $\begin{array}{c}14 \\
\text { days. }\end{array}$ & $\begin{array}{c}2 \\
\text { days. }\end{array}$ & $\begin{array}{c}5 \\
\text { days. }\end{array}$ & $\begin{array}{c}14 \\
\text { days. }\end{array}$ & $\begin{array}{c}2 \\
\text { days. }\end{array}$ & $\begin{array}{c}5 \\
\text { days. }\end{array}$ & $\begin{array}{c}14 \\
\text { days. }\end{array}$ \\
\hline $\begin{array}{l}\text { Acid coagulat- } \\
\text { ing............. } \\
\text { Acid............ } \\
\text { Inert............. } \\
\text { Alkali......... } \\
\text { Peptonizing.... }\end{array}$ & $\begin{array}{r}\text { Perct. } \\
6.59 \\
11.39 \\
73.45 \\
.21 \\
8.3 \overline{5}\end{array}$ & $\begin{array}{r}\text { Perct. } \\
9.54 \\
12.55 \\
58.04 \\
7.86 \\
11.99\end{array}$ & $\begin{array}{r}\text { Perct. } \\
12.98 \\
9.74 \\
43.51 \\
19.66 \\
14.10\end{array}$ & $\begin{array}{c}\text { Perct. } \\
20.05 \\
11.27 \\
67.46 \\
\cdots 1.21\end{array}$ & $\begin{array}{r}\text { Perct. } \\
23.12 \\
27.48 \\
45.02 \\
2.39 \\
1.98\end{array}$ & \begin{tabular}{|r|} 
Perct. \\
31.89 \\
34.87 \\
24.00 \\
5.63 \\
3.59
\end{tabular} & $\begin{array}{r}\text { Pcrct. } \\
6.14 \\
4.67 \\
81.37 \\
.09 \\
7.69\end{array}$ & $\begin{array}{r}\text { Perct. } \\
7.66 \\
5.17 \\
66.89 \\
6.53 \\
13.73\end{array}$ & $\begin{array}{r}\text { Perct. } \\
8.45 \\
7.18 \\
50.09 \\
17.79 \\
16.47\end{array}$ & $\begin{array}{r}\text { Pcrct. } \\
10.58 \\
6.72 \\
82.30 \\
.03 \\
.35\end{array}$ & $\begin{array}{r}\text { Perct. } \\
12.86 \\
27.98 \\
55.84 \\
2.43 \\
.87\end{array}$ & $\begin{array}{r}\text { Perct. } \\
18.73 \\
29.72 \\
40.63 \\
7.92 \\
2.99\end{array}$ \\
\hline Total.. & $\overline{99.89}$ & $99 . \overline{98}$ & 99.99 & 99.99 & 99.99 & $\overline{99.98}$ & $\overline{99.96}$ & $\overline{99.98}$ & $\overline{99.98}$ & 99.98 & $\overline{99.98}$ & 99.99 \\
\hline $\begin{array}{l}\text { Number of sam- } \\
\text { ples averaged }\end{array}$ & 16 & 17 & 17 & 19 & 20 & 20 & 17 & 18 & 18 & 21 & 22 & 22 \\
\hline
\end{tabular}

GRADE C MILK BEFORE AND AFTER PASTEURIZATION FOR 30 MINUTES AT $62.8^{\circ}$ C. $\left(145^{\circ} \mathrm{F}\right.$.)

When grade $\mathrm{C}$ milk was studied in the same manner, the percentage of the acid-coagulating group in pasteurized milk was found to be small and the group inactive. The averaged results in Table 14, and shown graphically in figure 13, bring out this point. It will be seen that the acid-coagulating group percentage was very small up to the 14 days' incubation period. The acid group also was rather inactive as indicated by the percentages. A large part of the peptonizing group developed slowly, as indicated by the increase in the percentage of groups shown in the various plots.

TABLE 14.-Changes in the bacterial group relations in grade $C$ milk when determined by litmus milk reactions after different lengths of incubation-Milk pasteurized at $62.8^{\circ} \mathrm{C}$. $\left(145^{\circ} \mathrm{F}\right.$.) for 30 minutes.

\begin{tabular}{|c|c|c|c|c|c|c|c|c|c|c|c|c|}
\hline \multirow{3}{*}{$\begin{array}{l}\text { Bacterial } \\
\text { groups. }\end{array}$} & \multicolumn{6}{|c|}{ Infusion agar plates. } & \multicolumn{6}{|c|}{ Casein agar plates. } \\
\hline & \multicolumn{3}{|c|}{ Raw milk. } & \multicolumn{3}{|c|}{ Pasteurized milk. } & \multicolumn{3}{|c|}{ Raw milk. } & \multicolumn{3}{|c|}{ Pasteurized milk. } \\
\hline & $\stackrel{2}{2}$ days. & $\begin{array}{c}5 \\
\text { days. }\end{array}$ & $\begin{array}{c}14 \\
\text { days. }\end{array}$ & $\begin{array}{c}2 \\
\text { days. }\end{array}$ & $\begin{array}{c}5 \\
\text { days. }\end{array}$ & $\begin{array}{c}14 \\
\text { days. }\end{array}$ & $\begin{array}{c}2 \\
\text { days. }\end{array}$ & $\begin{array}{c}5 \\
\text { days. }\end{array}$ & $\begin{array}{c}14 \\
\text { days. }\end{array}$ & $\begin{array}{c}2 \\
\text { days. }\end{array}$ & $\begin{array}{c}5 \\
\text { days. }\end{array}$ & $\begin{array}{c}14 \\
\text { days. }\end{array}$ \\
\hline 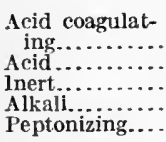 & $\begin{array}{r}\text { Per ct. } \\
18.10 \\
15.18 \\
64.54 \\
.20 \\
1.96\end{array}$ & $\begin{array}{r}\operatorname{Per} c \dot{.} \\
31.33 \\
9.42 \\
4944 \\
1.66 \\
8.13\end{array}$ & $\begin{array}{r}\text { Perct. } \\
33.85 \\
6.85 \\
43.13 \\
3.33 \\
12.81\end{array}$ & $\begin{array}{r}\text { Per ct. } \\
0.06 \\
6.82 \\
91.21 \\
\hdashline 1.89\end{array}$ & $\begin{array}{r}\text { Perct. } \\
0.35 \\
43.02 \\
53.46 \\
.06 \\
3.09\end{array}$ & $\begin{array}{r}P e r c t . \\
11.85 \\
61.25 \\
22.06 \\
.36 \\
4.47\end{array}$ & \begin{tabular}{|r|} 
Perct. \\
7.25 \\
5.59 \\
84.53 \\
\hdashline .61
\end{tabular} & $\begin{array}{r}\text { Perct. } \\
9.96 \\
7.17 \\
76.09 \\
1.11 \\
5.65\end{array}$ & $\begin{array}{r}\text { Perct. } \\
9.90 \\
7.94 \\
63.79 \\
5.90 \\
12.44\end{array}$ & $\begin{array}{c}\text { Perct. } \\
0.36 \\
1.96 \\
93.02 \\
\cdots . . . \\
4.65\end{array}$ & $\begin{array}{r}\text { Perct. } \\
0.36 \\
19.84 \\
71.53 \\
.90 \\
7.35\end{array}$ & $\begin{array}{r}\text { Perct. } \\
3.19 \\
34.57 \\
49.74 \\
2.99 \\
9.49\end{array}$ \\
\hline Total.... & 99.98 & 99.98 & 99.97 & 99.98 & 99.98 & 99.99 & 99.98 & 99.98 & 99.97 & 99.99 & 99.98 & 99.98 \\
\hline $\begin{array}{l}\text { Number of sam- } \\
\text { ples averaged }\end{array}$ & 12 & 12 & 12 & 11 & 11 & 11 & 9 & 9 & 9 & 11 & 11 & 11 \\
\hline
\end{tabular}

It is interesting to note the activity of the total acid group in pasteurized milk of grade $B$, and although the average bacterial count was high this grade of milk more nearly represents the ordinary quality of milk which is pasteurized commercially than either grades A or C. 


\section{COMPARISON OF THE PERCENTAGE OF ACID-FORMING BACTERIA IN RAW AND PASTEURIZED MILK.}

As has already been shown, the acid bacteria instead of being destroyed by pasteurization for 30 minutes at $62.8^{\circ} \mathrm{C} .\left(145^{\circ} \mathrm{F}\right.$.) are actually increased in their percentage of the total bacteria. The large percentage of the acid group which survive the process are shown in the frequency curve in figure 14. The number of samples were plotted as ordinates and the percentage of the acid-forming bacteria as abscissæ, the ranges in percentages from $0-1, \quad 1-10$, 10-20, etc., being taken as points. Thirty-nine samples of raw and 42 of pasteurized milk were examined. The samples of milk were pasteurized for 30 minutes at $62.8^{\circ} \mathrm{C}$. $\left(145^{\circ} \mathrm{F}\right.$.). It will be seen from the figure that with

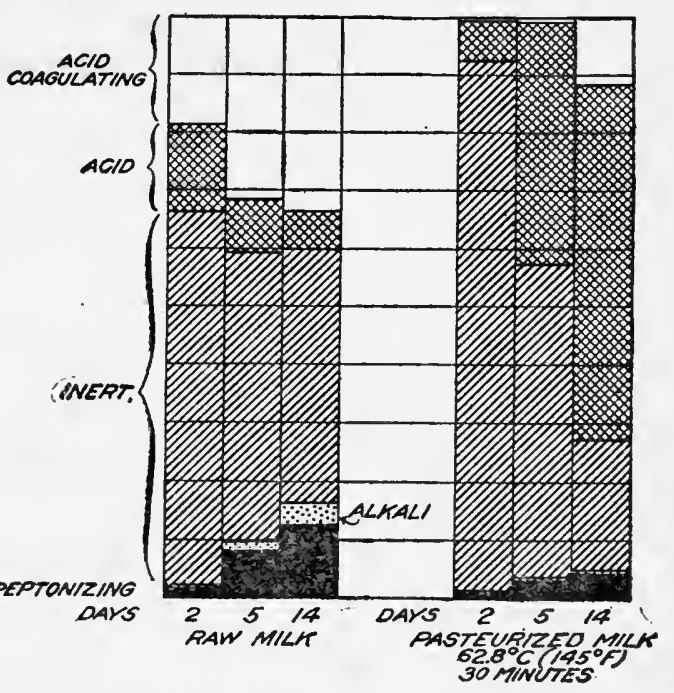

FIG. 13.-Changes in the bacterial group relations in grade C milk when determined by litmus milk reactions after different lengths of incubation.

the raw milk the peak of the curve is at 1-10, while one peak of the curve of pasteurized milk is at 10-20 and another at 50-60. In other

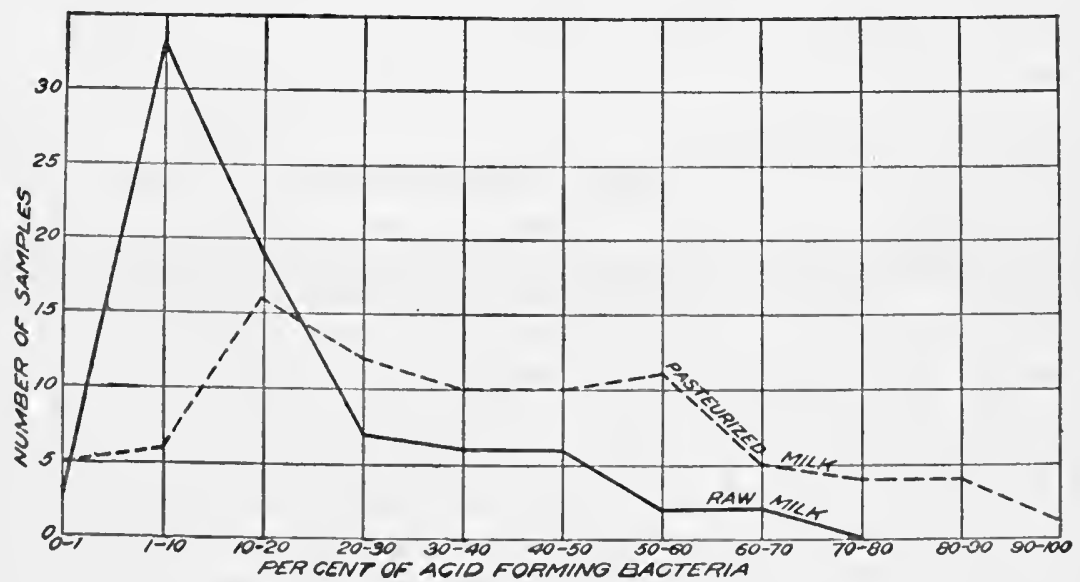

Fig. 14.-Comparison of the percentage of the acid-forming bacteria in raw and pasteurized nilk.

words, the majority of the samples of raw milk contained from 1 to 10 per cent of bacteria of the acid group. The number of samples con- 
taining higher percentages gradually diminished until no sample contained over 80 per cent. Among the samples of the pasteurized milk, it may be seen from the curve that the majority of them contained from 10 to 60 per cent of the acid group and some samples as high as 90 per cent.

\section{COMPARISON OF THE PERCENTAGE OF PEPTONIZING BACTERIA IN RAW AND PASTEURIZED MILK.}

In the same manner 39 samples of raw milk and 42 samples of milk pasteurized for 30 minutes at $62.8^{\circ} \mathrm{C}$. $\left(145^{\circ} \mathrm{F}\right.$.) have been grouped according to the percentage of peptonizing bacteria which they contained. A comparison of the frequency curves in figure 15 shows that the pasteurized milk contained a lower percentage of the peptonizing group than did the raw milk. A large number of samples of pasteurized milk contained between 0 and 1 per cent of peptonizing

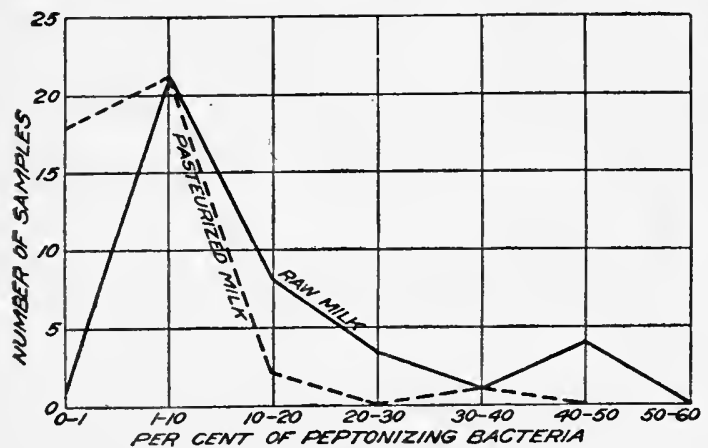

FIG. 15.-Comparison of the percentage of the peptonizing bacteria ized milk contained in raw and pasteurized milk.

cent of the peptonizing group. However, in a comparison of the raw and pasteurized milk it was found that a larger number of samples of raw milk contained the high percentages of peptonizers.

\section{AVERAGE PERCENTAGES OF THE BACTERIAL GROUPS OF RAW MILK WHICH SURVIVE PASTEURIZATION.}

The effect of pasteurization upon the bacteria in milk may be shown by a determination of the percentage of the bacterial groups of raw milk which are found after heating. This percentage was obtained by subtracting the percentage reduction by pasteurization of the various groups from 100 per cent. The samples of raw and pasteurized milk were plated on infusion and casein agar and the percentage reduction of the various groups determined by the milk tube method. Table 15 shows the averaged results from infusion and casein agar plates, using three grades of milk for examination. 
It may be seen that a greater percentage of the acid group of bacteria in the raw milk remained after heating than any of the other groups. As a rule a smaller percentage of the peptonizing group survived than either of the other groups. In general the result when casein agar was used was higher, although the reason is not apparent.

TABLE 15.-Average percentages of the bacterial groups of raw milk which survive pasteurization by the "holder" process.

\begin{tabular}{|c|c|c|c|c|c|}
\hline \multirow{2}{*}{$\begin{array}{l}\text { Pasteurization temper- } \\
\text { ature. }\end{array}$} & \multirow[b]{2}{*}{ Media. } & \multicolumn{4}{|c|}{ Bacterial groups. } \\
\hline & & Acid. & Inert. & Alkali. & $\begin{array}{l}\text { Pepton- } \\
\text { izing. }\end{array}$ \\
\hline $\begin{array}{l}\text { Grade } A, 62.8^{\circ} \mathrm{C} .\left(145^{\circ} \mathrm{F} .\right) \\
\text { Grade } A, 71.1^{\circ} \mathrm{C} .\left(160^{\circ} \mathrm{F} .\right) \\
\text { Grade } \mathrm{B}, 62.8^{\circ} \mathrm{C} .\left(145^{\circ} \mathrm{F} .\right) . \\
\text { Grade } \mathrm{C}, 62.8^{\circ} \mathrm{C} .\left(145^{\circ} \mathrm{F} .\right) .\end{array}$ & 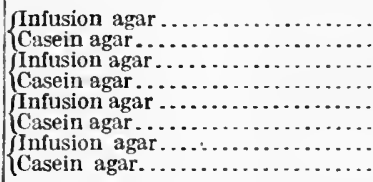 & $\begin{array}{r}1.27 \\
4.26 \\
1.71 \\
2.34 \\
6.98 \\
6.50 \\
4.55 \\
13.09\end{array}$ & $\begin{array}{r}0.37 \\
.31 \\
.12 \\
.39 \\
1.48 \\
2.06 \\
1.59 \\
4.49\end{array}$ & $\begin{array}{r}0.05 \\
1.55 \\
.10 \\
0 \\
1.27 \\
2.05 \\
.19 \\
1.13\end{array}$ & $\begin{array}{r}0.05 \\
.08 \\
.01 \\
.03 \\
1.86 \\
.51 \\
1.24 \\
1.25\end{array}$ \\
\hline
\end{tabular}

\section{THE EFFECT OF PASTEURIZATION ON THE NUMBER OF BACTERIA OF DIFFERENT GROUPS IN MILK.}

In order to show the effect of pasteurization on the numbers of the bacteria of different groups, Table 16 has been arranged. This shows the calculated number of bacteria in each group determined from the average total counts on infusion agar and the group percentages as shown by the milk-tube method. To illustrate this further take the samples from dairy $A$, as shown in Table 16. The bacterial count of 12 samples of raw milk averaged was 21,100. The averaged group percentages of the 12 samples was 33.85 per cent of the acid-coagulating group, 6.55 per cent of the acid group, and so on. The acid-coagulating group contained on an average 33.85 per cent of the average total count, or approximately 7,160 bacteria per cubic centimeter. The other bacterial numbers were calculated in the same way. 
TABLE 16.-Comparison of the number of bacteria of different groups in milk before and after pasteurization.

\begin{tabular}{|c|c|c|c|}
\hline A verage total count per cubic centimeter. & $\begin{array}{c}\text { Average } \\
\text { group } \\
\text { per- } \\
\text { centage. }\end{array}$ & Group. & $\begin{array}{l}\text { Calculated } \\
\text { number of } \\
\text { each group } \\
\text { per cubic } \\
\text { centimeter. }\end{array}$ \\
\hline \multirow{5}{*}{ liaw milk, 21,100 . A verage of 12 samples. Dairy $A$. } & 33.85 & Acid-coagu & 7,160 \\
\hline & 6.85 & Acid....... & 1,450 \\
\hline & 43.13 & Inert... & 9,120 \\
\hline & $\begin{array}{r}3.33 \\
12.81\end{array}$ & $\begin{array}{l}\text { Alkali........ } \\
\text { Peptonizing. }\end{array}$ & $\begin{array}{r}705 \\
2.700\end{array}$ \\
\hline & 11.85 & Acid-coagulating. & 50 \\
\hline \multirow{3}{*}{$\begin{array}{l}\text { Pasteurized milk, } 62.8^{\circ} \mathrm{C} .\left(145^{\circ} \mathrm{F} \text { ) }\right), 30 \text { minutes, } 420 . \\
\text { A verage of } 11 \text { samples. Dairy A.................. }\end{array}$} & 61.25 & Acid... & 257 \\
\hline & $\begin{array}{r}22.06 \\
.36\end{array}$ & $\begin{array}{l}\text { Inert... } \\
\text { Alkali. }\end{array}$ & 92 \\
\hline & 4.47 & Peptonizing & 19 \\
\hline & 12.98 & Acid-coagulating. & 368,800 \\
\hline \multirow{4}{*}{ 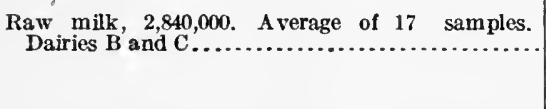 } & $\begin{array}{r}9.74 \\
43.51\end{array}$ & Acid........ & $\begin{array}{r}276,700 \\
1,236,000\end{array}$ \\
\hline & 19.66 & Alkali. & 558,000 \\
\hline & 14.10 & Peptonizing & 400,000 \\
\hline & 31.89 & Acid-coagulating. . & 3,760 \\
\hline \multirow{4}{*}{$\begin{array}{l}\text { Pasteurized milk, } 62.8^{\circ} \text { C. }\left(145^{\circ} \text { F.), } 30 \text { minutes, }\right. \\
11,700 . \text { A verage of } 20 \text { samples. Dairies } B \text { and C... }\end{array}$} & 34.87 & Acid.... & 4,110 \\
\hline & 5. 63 & Alkali. & 660 \\
\hline & 3.59 & Peptonizing..... & 420 \\
\hline & 36.17 & Acid-coagulating. & $8,200,000$ \\
\hline \multirow{4}{*}{ 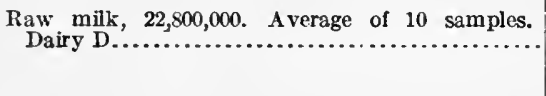 } & 10.71 & Acid.... & $2,450,000$ \\
\hline & $\begin{array}{r}29.31 \\
6.47\end{array}$ & Alkali. & $1,480,000$ \\
\hline & 17.31 & Peptonizing.... & $3,900,000$ \\
\hline & 17.91 & Acid-coagulating.... & 14.900 \\
\hline \multirow{3}{*}{$\begin{array}{l}\text { Pasteurized milk, } 62.8^{\circ} \mathrm{C} .\left(145^{\circ} \mathrm{F} .\right), 30 \text { minutes, } \\
83,000 . \quad \text { A verage of } 12 \text { samples. Dairy D......... }\end{array}$} & 61.87 & Acid ................. & 51,500 \\
\hline & 9.06 & Inert...... & 7,500 \\
\hline & 1.39 & Peptonizing... & 1,150 \\
\hline
\end{tabular}

The most striking features of the table is the high number of acidforming bacteria in proportion to the low number of peptonizers in the pasteurized milk and the marked difference in the numbers of peptonizing bacteria before and after pasteurization. The milk from dairy $A$ was exceptionally good, the average total count of the raw milk being 21,100 and after pasteurization for 30 minutes at $62.8^{\circ} \mathrm{C}$. $\left(145^{\circ} \mathrm{F}\right.$.) only 420 per cubic centimeter. The peptonizers were reduced from 2,700 to 19 per cubic centimeter.

The milk from dairies $\mathrm{B}$ and $\mathrm{C}$ was of poorer quality, the average count of the raw milk being 2,840,000. After pasteurization the count was 11,700 . The peptonizers were reduced by the process from $400 ; 000$ to 420 per cubic centimeter. In the last part of the table the results of the examination of poor milk is shown. The average count was 22,800,000 bacteria per cubic centimeter before and 83,000 after pasteurization for 30 minutes at $62.8^{\circ} \mathrm{C}$. $\left(145^{\circ} \mathrm{F}\right.$.). The raw milk contained an average of $3,900,000$ peptonizers per cubic centimeter and after pasteurization only 1,150 per cubic centimeter. Throughout the whole series may be noticed the low number of alkali-forming bacteria in the pasteurized milk in proportion to those in the raw milk. After a comparison is made of the kinds of bacteria in the raw milk 
from dairies $\mathrm{B}$ and $\mathrm{C}$ and in the extremely poor milk from dairy $\mathrm{D}$ with the same milk after pasteurization there should be no question as to the beneficial effect of the process.

THE BACTERIAL DEVELOPMENT IN MILK PASTEURIZED IN THE LABORATORY AND HELD AT DIFFERENT TEMPERATURES.

After having determined the groups of bacteria which survived pasteurization, their subsequent development was traced in a few samples of milk.

The changes in the bacterial flora of milk pasteurized for 30 minutes at $62.8^{\circ} \mathrm{C} .\left(145^{\circ} \mathrm{F}\right.$.) during storage at different temperatures has been studied in a poor, medium, and good grade of milk. One sample of each grade of milk was divided and each part pasteurized in a sterile flask. After pasteurization each sample was held in the ice box at approximately $7.23^{\circ} \mathrm{C}$. $\left(45^{\circ} \mathrm{F}\right.$.) for 18 hours; then one flask was held at room temperature, the other was kept in the ice box. After pasteurization and on each successive day each sample was plated to determine the number of bacteria which were then differentiated by the milk-tube method. On account of the great amount of work involved and time consumed in determining the bacterial flora by the milk-tube method only one sample of each grade was studied. 


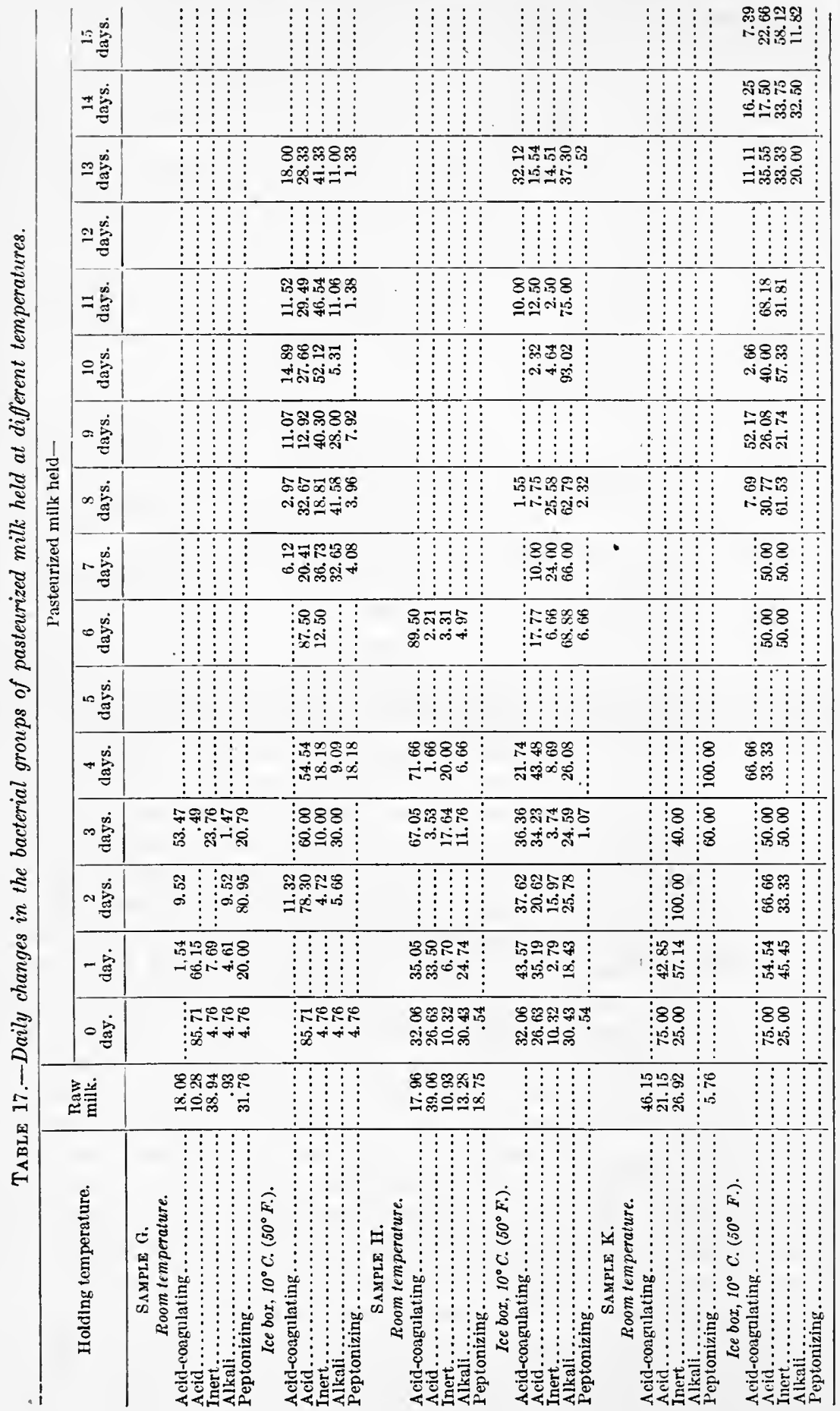


The daily bacterial group percentages are shown in Table 17 . The room temperature varied from $21.1^{\circ}-23.9^{\circ} \mathrm{C}$. $\left(70^{\circ}-75^{\circ} \mathrm{F}\right.$.) while the temperature of the ice box ranged from $8^{\circ}-10^{\circ} \mathrm{C} .\left(46.4^{\circ}-50^{\circ} \mathrm{F}\right.$.). The bacterial group percentages in each raw milk are shown followed by the " 0 " day determination which gives the group percentages immediately after pasteurization. Sample G represented a poor quality of milk, $\mathrm{H}$ a milk of medium quality, such as is usually commercially pasteurized, and sample $K$ an excellent grade of milk containing only a few thousand bacteria per cubic centimeter. The saniples of milk

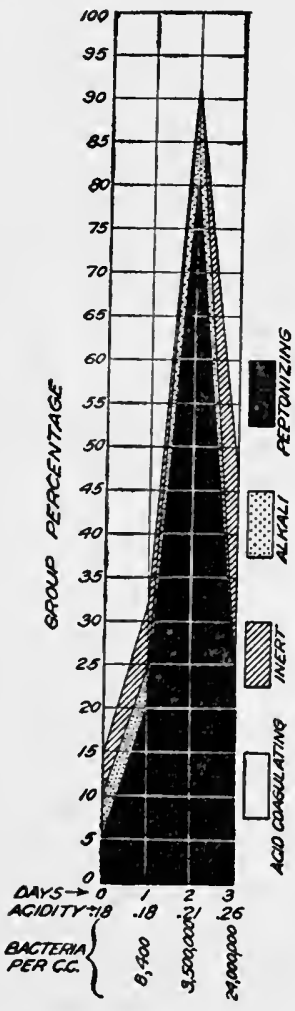

Fig. 16.-Daily changes in the bacterial group relations in pasteurized milk. Sample $G$ held at room temperature.

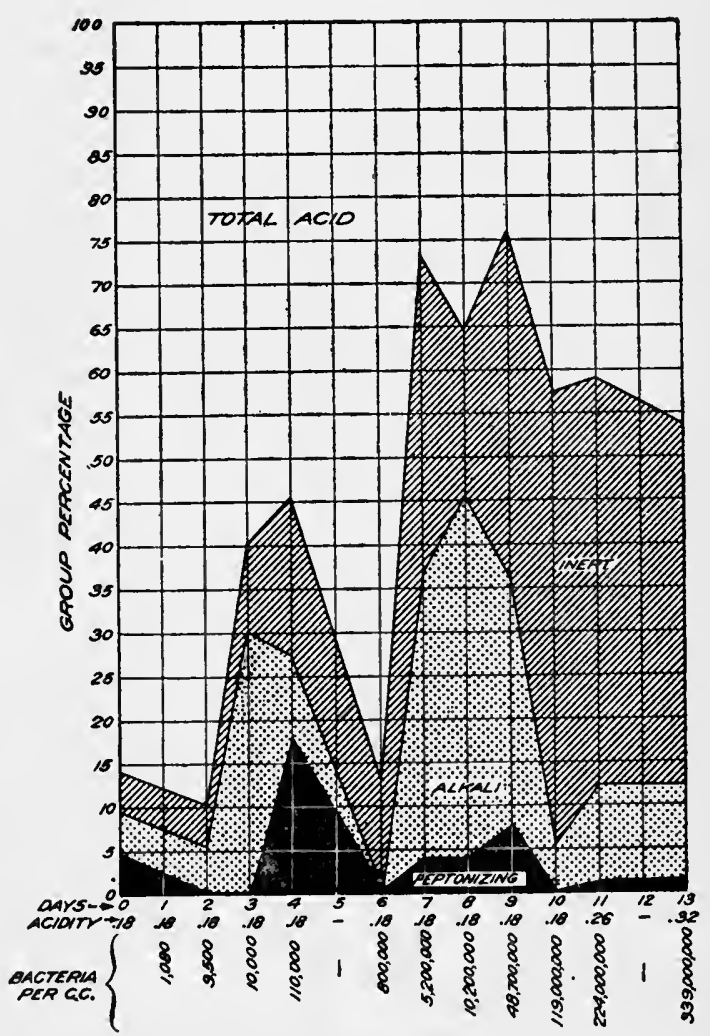

FIG. 17.-Daily changes $\ln$ the bacterial group relations in pasteurized milk. Sample $\mathrm{G}$ held in the ice box.

were pasteurized and held so as to prevent any possible rcinfection. In order to show the changes in the groups more plainly, the results from Table 17 have been plotted. Figure 16 shows the changes in the bacterial flora of sample $\mathrm{G}$ held at room temperature. This sample showed a rennet curd on the third day. While there was a little acid development during the first three days, a rapid increase occurred from the third to the fourth day. From the figure it may be seen that there was a rapid increase in the percentage of the peptonizing group from 4.75 per cent on " 0 " day to 20 per cent after one 
day, then to 80.95 per cent after two days, followed by a drop to 20.79 per cent the third day. Corresponding to the increase in the proportion of the peptonizing group there was a decrease in the acid group followed by an increase on the third day. The acid group comprised 85.71 per cent of the bacteria at first, then dropped to 67.69 per cent after one day, then to 9.52 on the second day, then increased 53.96 per cent. The percentage of the alkali group throughout was low. As the plot shows, there was a rapid increase in the peptonizing bacteria which produced a rennet curd on the third day. Up to that

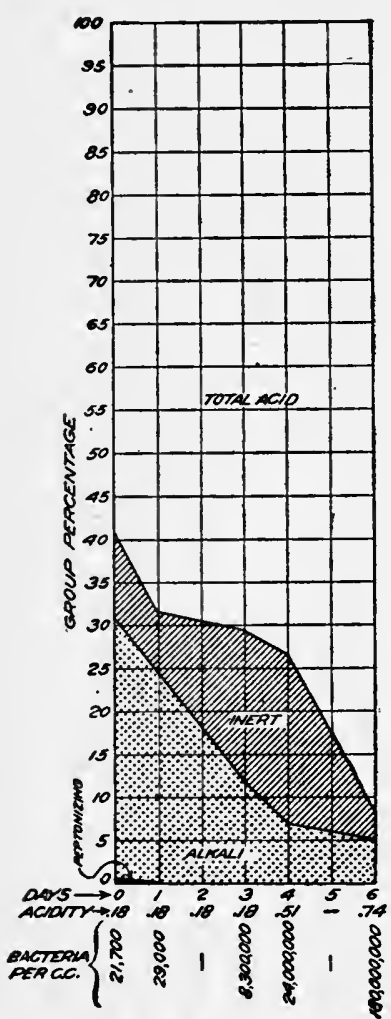

FIG.18.-Daily changes in the bacterial group relations in pasteurized milk. Sample $H$ held at room temperature. time the development of the acid-forming bacteria was slow, and while there was some development of acid, apparently not enough was formed to check the development of the peptonizing group. To summarize, it may be said that in sample G, held at room temperature, there was a rapid growth of peptonizing organisms which produced a rennet curd, followed by acid devclopment produced by the growth of the acid-forming bacteria.

The other portion of sample $\mathrm{G}$ was held in the ice box. Figure 17 shows the rosults graphically. It may be seen thet there was only a slight acid development during the 13 days' holding period. The most striking point is the restriction of the development of the peptonizing group by the low temperature at which the sample was held. A comparison of the plot of the peptonizing group in figures 16 and 17 shows this point plainly. There was a slow bacterial development during the first six days as shown by the total counts. During that time the percentage of the acid group was high. From the seventh to the ninth day the per cent of the acid group was low, with a corresponding increase in the alkali and inert groups. From the ninth day the percentage of the acid group began to increase and the acidity also increased. The bacterial groups were not studied after the thirteenth day, but the sample was held and acidity was determined daily. It was found that the milk eventually soured. After eight days an old taste developed which would prevent its consumption as a food.

The changes in the bacterial flora of a better grade of milk represented by sample $H$ were much different when the milk was held at room temperature. As may be seen from figure 18 the milk soured with a constantly increasing percentage of the acid group and decrease 
in the other group percentages. The percentage of the acid group increased from 58.69 after pasteurization to 91.71 after six days.

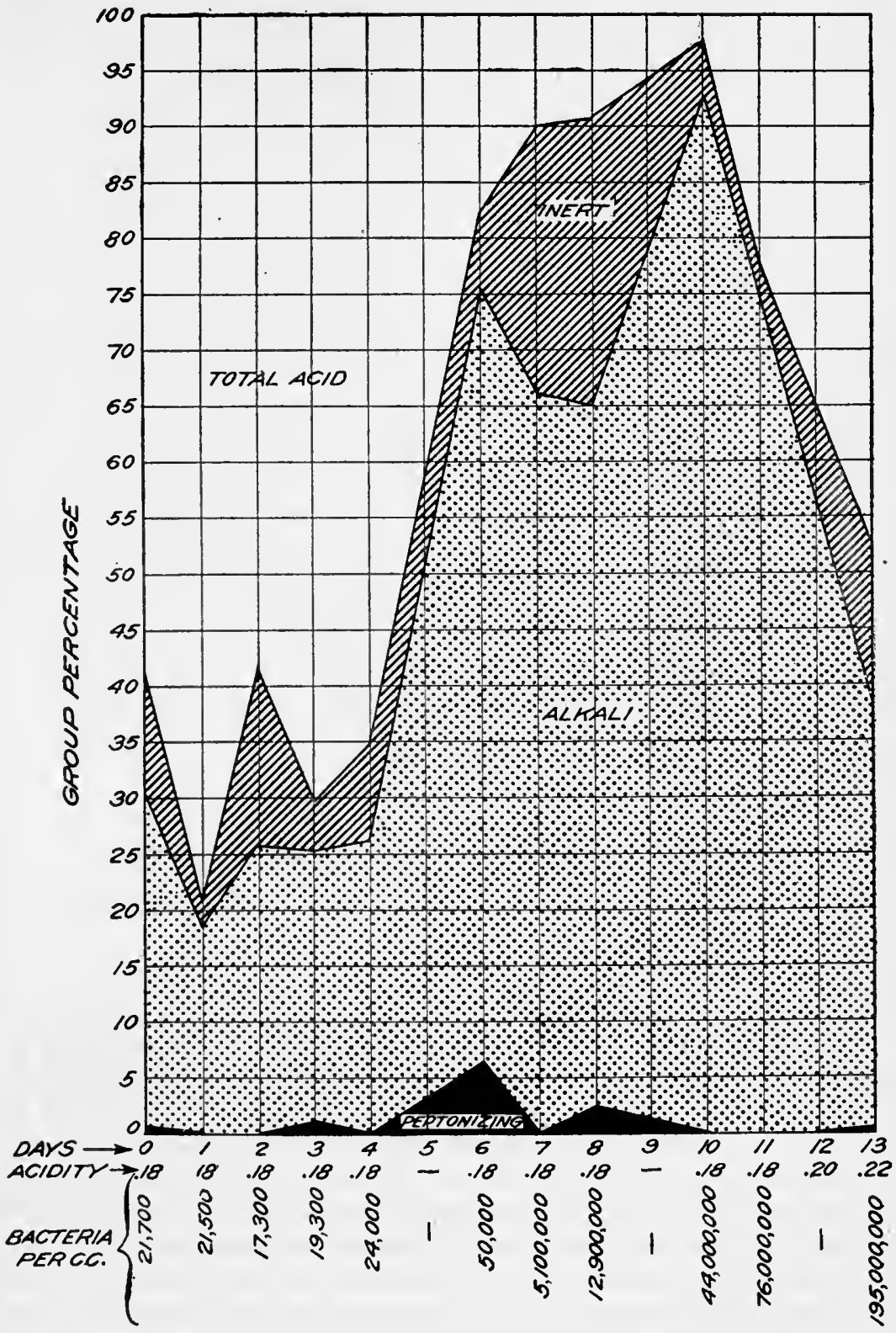

FIG. 19.-Daily changes in the bacterial group relations in pasteurized milk. Sample II held in ice box.

The percentage of the peptonizing group was 0.54 immediately after heating and none appeared in the plates in the later examinations. The changes in the groups of the other portion of sample $H$ held in the ice box are shown in figure 19. The development of the alkali 
group after four days is plainly shown. With the increase in the percentage of the alkali group there was a corresponding decrease in the acid group. After 10 days the percentage of the alkali group began to decrease and the acid group to increase. The percentage of the peptonizing group was low through the whole period. The acidity did not change until the twelf th day. After 11 days the milk had an old taste and would not be used.

The changes in the bacterial groups in the best grade of milk represented by sample $K$ were different from the others when the milk was

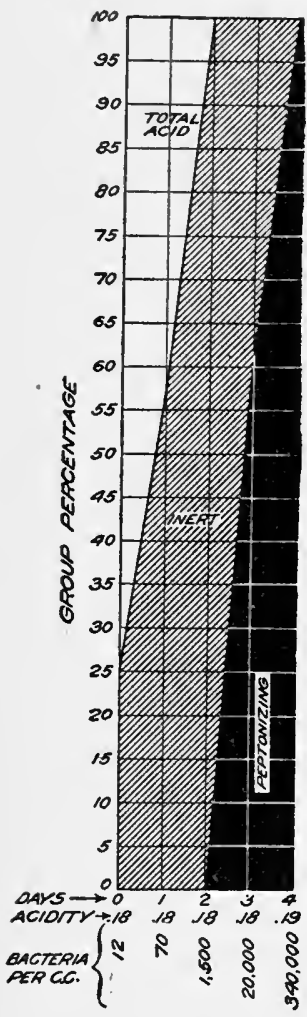

FIG. 20.-Daily changes in the bacterial group ralations in pasteurized milk. Sample $\mathbf{K}$ held at room temperature.

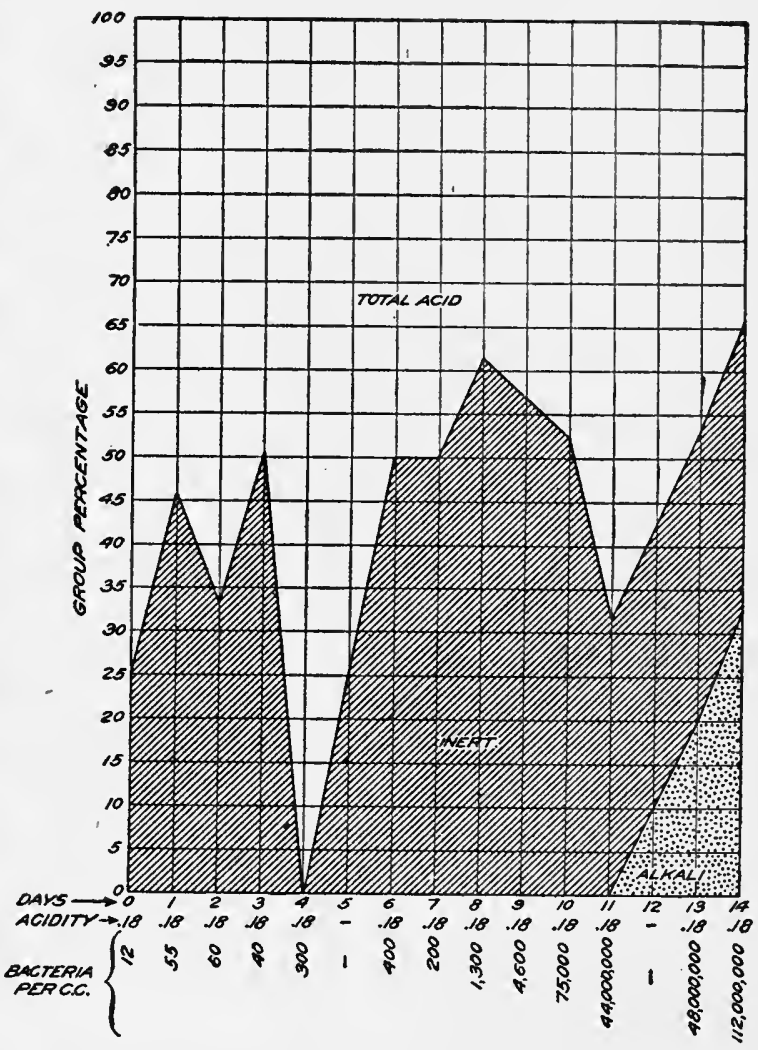

FIG. 21.-Daily changes in the bacterial group relations in pasteurized milk. Sample $\mathrm{K}$ held in the ice box.

held at room temperature. After six days the milk was putrid and digested, but had not coagulated. As may be seen from figure 20, there was no acid formed. On the second day the peptonizing bacteria began to increase rapidly, and on the fourth day only organisms of the peptonizing group were found. The acid group gradually decreased until the second day, after which none appeared on the plates. The extreme changes in the group percentages were due to the low number of bacteria in the milk. When only a few colonies appeared on a plate the determination of the groups was of course, 
much less accurate than when 100 or more colonies are studied by the milk-tube method.

The restraining effect of low temperatures on the development of the peptonizing group is again plainly shown in figure 21 , which represents the bacterial group changes in the other portion of sample $\mathrm{K}$ held in the ice box. No peptonizing bacteria were found on the plates throughout the whole series and none of the alkali group appeared until the twelfth day. The acid group predominated throughout with considerable fluctuation due to inaccuracy on account of low bacterial numbers. The total counts were very low until the eleventh day, after which there was a rapid increase. After 17 days an old taste was noticed and at that time the acidity began to increase slowly.

These results are shown merely to indicate the possible changes which may take place in milk pasteurized in sealed bottles. It is clear that there is a delicate balance between the various bacterial groups which may be influenced by conditions of temperature and time so that various effects may be produced. These results can not be applied to commercial problems, since in laboratory experiments it is impossible to duplicate commercial conditions. In order to determine the changes in milk commercially pasteurized in sealed bottles a study must be carried on only under commercial conditions.

\section{QUALITATIVE STUDY OF THE GROUPS OF BACTERIA WHICH SURVIVE PASTEURIZATION.}

During the determination of the percentage of the bacterial groups cultures were selected for further study. These were selected from milk pasteurized at $62.8^{\circ} \mathrm{C}$. $\left(145^{\circ} \mathrm{F}\right.$.) for 30 minutes. The cultures were purified by plating, then examined microscopically and for their cultural reactions. In the tables of the Appendix the complete reactions are shown.

\section{TII ACID-FORMING GROUP OF BACTERIA.}

The acid-forming group of bacteria have been grouped arbitrarily as shown in figure 22 . One hundred and thirty-two cultures were examined and were divided into four classes. The first class comprised 89.39 per cent of the cultures. The reactions of this class are shown in figure 22. All the organisms were cocci which produced no liquefaction of gelatin. The Gram stain was either positive or negative, nitrate was not reduced, and some formed pigment while others did not. Dextrose, galactose, and lactose were fermented. Some cultures fermented saccharose. Of those that fermented saccharose, the ability to ferment raffinose, starch, inulin, mannite, glycerin, and salicin varied as may be seen. The same may be said regarding those cultures which did not ferment saccharose. The second class was made 
up of nonliquefying bacilli, Gram positive, nitrate reduction positive or negative, and all produced pigment. Dextrose, galactose, lactose, and saccharcse were fermented; raffinose positive or negative, starch positive or negative, inulin not fermented, mannite positive or negative, glycerin not fermented, and salicin positive or negative. This class comprised 3.03 per cent of the acid group cultures. The third

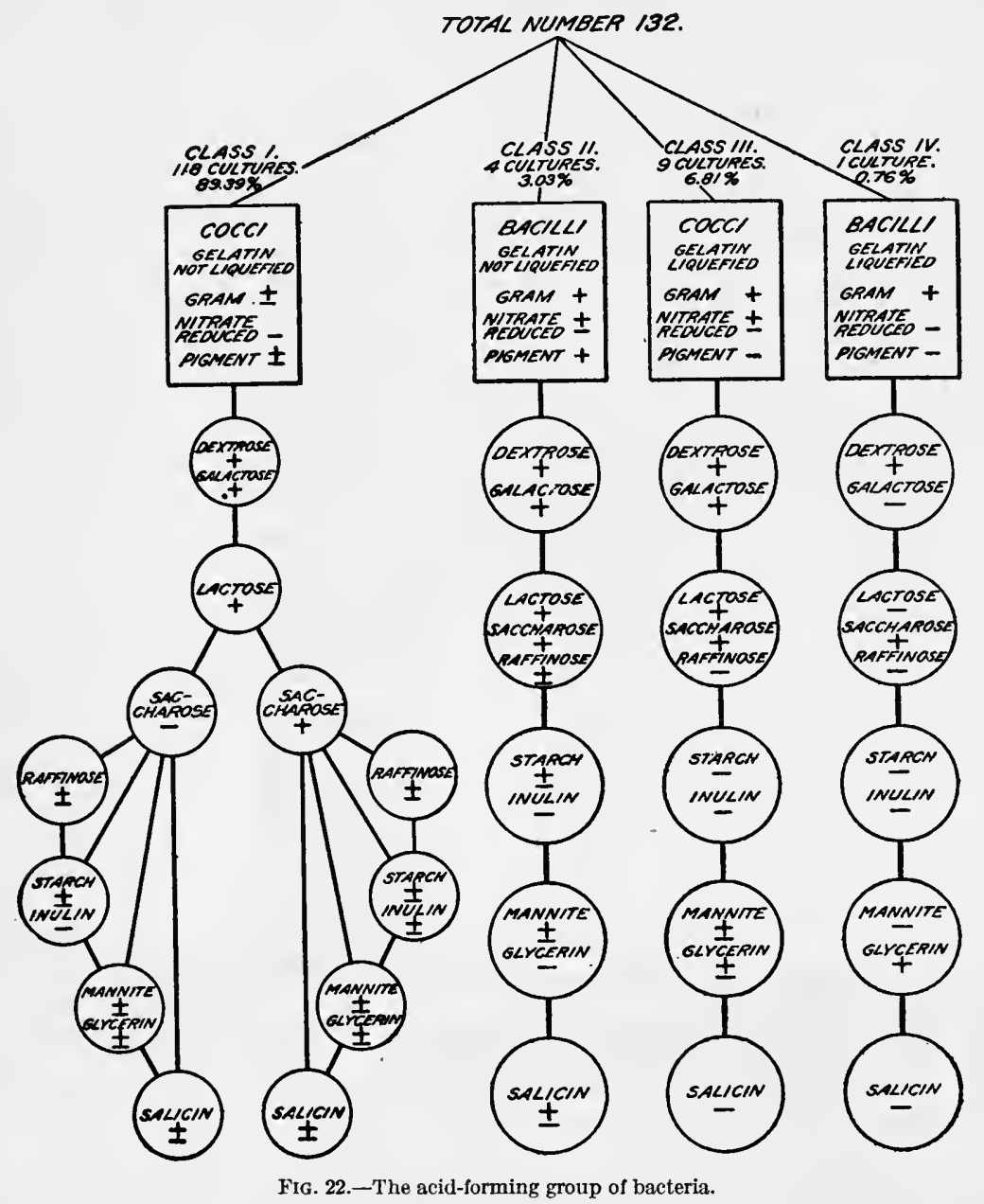

class contained 6.81 per cent of the cultures and was made up of liquefying cocci, Gram positive, nitrate reduction positive or negative, and none produced pigment. The acid production was as follows: Dextrose, galactose, lactose, and saccharose positive; raffinose, inulin, and starch negative; mannite and glycerin positive or negative; and salicin negative.

One culture formed the fourth class. It was a liquefying Gram positive bacillus which reduced nitrates and formed no pigment. 
Acid was formed in dextrose, lactose, saccharose, and glycerin. The complete reactions of each variety of bacteria are shown in Table I of the Appendix.

In general it may be said that the majority of the acid group which survived pasteurization at $62.8^{\circ} \mathrm{C}$. $\left(145^{\circ} \mathrm{F}\right.$.) were nonliquefying cocci which varied widely in their ability to ferment the various sugars. A small percentage of acid-forming bacilli also survived, together with a few acid-liquefying bacteria.

\section{THE INERT GROUP OF BACTERIA.}

The study of the inert group has not been given much attention. All bacteria which produced no change in litmus milk after 14 days' incubation at $30^{\circ} \mathrm{C}$. $\left(86^{\circ}\right.$ F.) were classed according to the milktube method as inert organisms. The group would therefore contain not only those bacteria which did not produce any change in milk under any condition, but also any organisms which did not happen to grow in the milk tubes and those which might produce a change in milk after the 14 days' incubation period.

In a number of samples agar streak cultures were male from

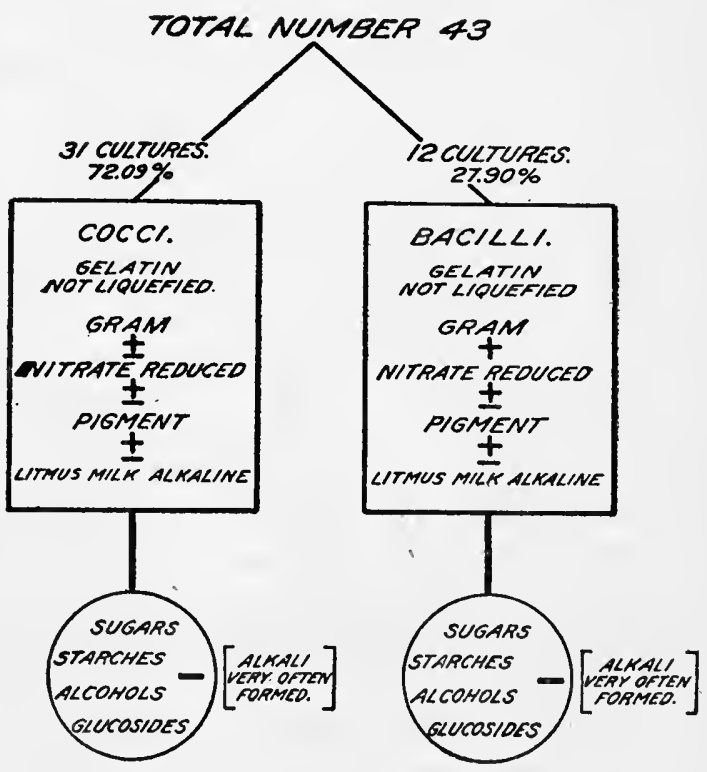

FIG. 23.-The alkali-forming group of bacteria. the litmus milk tubes which showed no change. Sometimes none of the agar cultures showed growth; in other cases approximately 2 per cent, 5 per cent, 25 per cent, 80 per cent, and occasionally 100 per cent showed growth on agar streaks. When those agar cultures were reinoculated into litmus milk, some would not produce any reaction and others a slight alkaline reaction after long incubation. Often a yellow color was noticed in the litmus milk culture which indicated an inert yellow pigment-forming organism.

\section{THF ALKALI-FORMING GROUP OF BACTERIA.}

The alkali-forming bacteria constitute a group, which has been given but little study in connection with the bacterial flora of milk. In 
the differentiation of the various groups on litmus lactose gelatin plates, organisms of this group would be entirely missed, but they are easily found by the milk-tube method. Forty-three of these organisms isolated from pasteurized milk have been studied and grouped arbitrarily, as shown in figure 23. The alkali group was made up of 72.09 per cent of cocci and 27.90 per cent of bacilli.

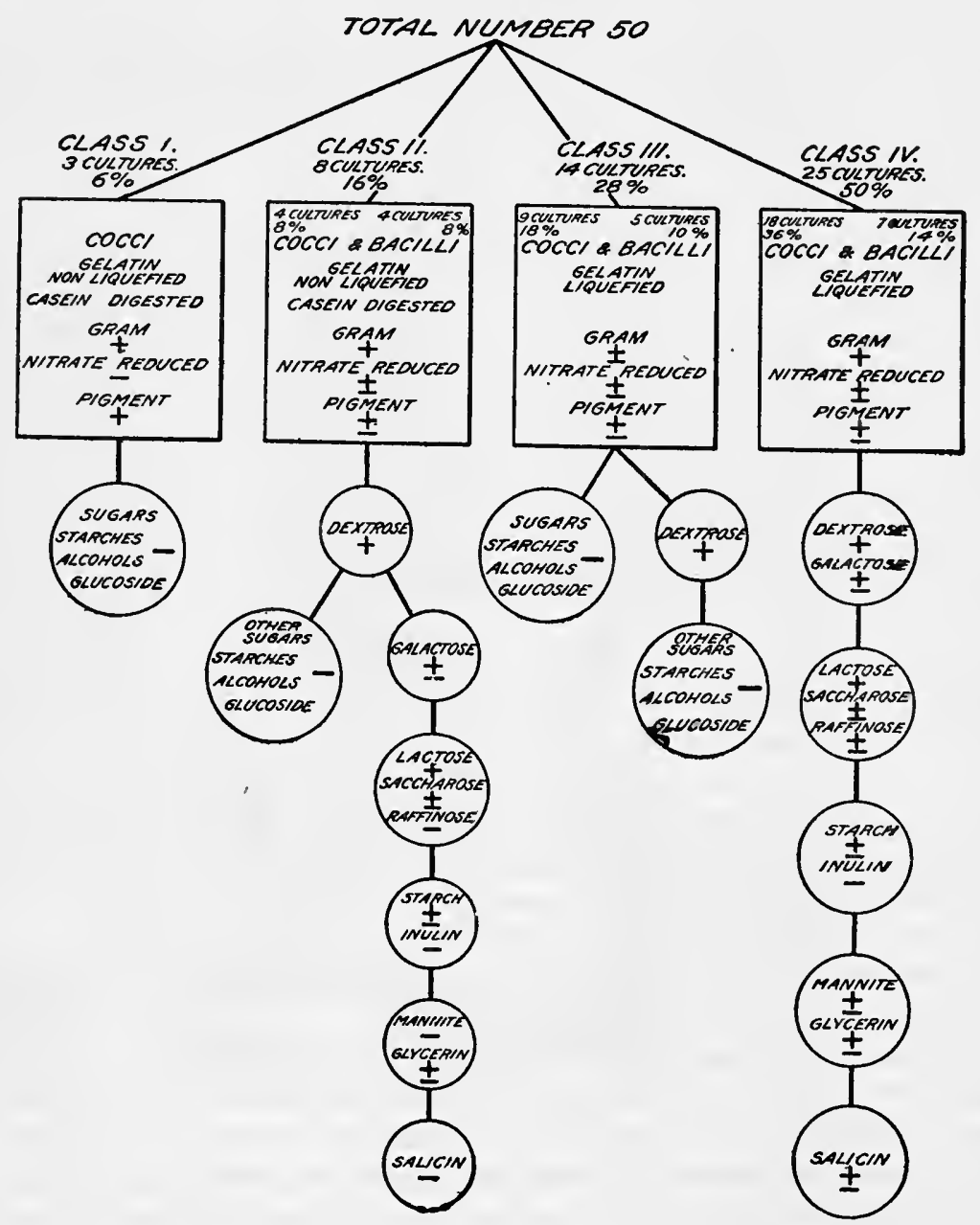

FIG. 24.-The peptonizing group of bacteria.

It is not necessary to go into minute details regarding these organisms, for their characteristics are plainly shown in the figure. They did not liquefy gelatin, and produced a strong alkaline reaction in litmus milk. No acid was produced in the sugars, starches, alcohols, or in the glucosid used in the investigation, but an alkaline reaction was often found. In litmus milk often enough alkali was produced to 
dissolve the casein. That will always happen if the period of incubation is long enough. The complete characteristics are shown in the Appendix in Table II. A more extended study of the alkali group is under way in the research laboratories of this division.

\section{THE PEPTONIZING GROUP OF BACTERIA.}

The peptonizing bacteria include only those which peptonize the casein of milk. Fifty of this type of organisms were studicd, and their characteristics are shown fully in the Appendix in Table III. They were divided arbitrarily into four classes, as shown in figure 24 . It may be seen that the bacteria of classes 1 and 2 did not liquefy gelatin during 30 days' incubation, but did peptonize casein. The peptonization of casein was determined by streak cultures on casein agar slopes by the following method:

After 14 days' incubation the slopes were flowed with N/10th lactic acid. If no peptonization has taken place the casein will be precipitated by the acid. If peptonization has gone on, then the casein agar will remain clear, showing that the casein has been dissolved. The use of casein agar for the determination of peptonizing bacteria in milk is fully described in another publication ${ }^{1}$ of this department. It will be seen from figure 24 that classes 1 and 2 comprise both cocci and bacilli, some of which did not ferment sugars, while others produced acid. Classes 3 and 4 is made up of bacteria which liquefy gelatin and may or may not ferment the sugars. It is interesting to note that out of 225 cultures of bacteria studied only 3 , or 1.35 per cent, formed spores. Those 3 cultures were found among the 50 peptonizing organisms making only 6 per cent of the peptonizing spore-forming organisms.

\section{TIE GAS-FORMING BACTERIA.}

During the study of 225 cultures selected at random from the samples of pasteurized milk only two organisms were found which produced gas in milk. One of the gas-forming bacteria, culture 417, was a Gram negative short bacillus which peptonized casein but did not liquefy gelatin. It produced gas in lactose broth and acid in dextrose, saccharose, raffinose, starch, and salicin broths. No acid was formed in lactose, gralactose, mannite, glyeerin, or inulin broths. Nitrate solution was redueed. Gas was produced in litmus milk and the milk was curdled with some peptonization. It is evident that this bacillus did not belong to the colon-aerogenes group.

The other organism is an entirely new type so far as known. 'This culture known as Z produced gas in milk but not in lactose broth.

\& Ayers, S. IIenry. Caseln media adapted to determining hacteria In milk. United States Department of Ajrlculture, Bureau of Animal Industry, Twenty-eighth Annual Report, 1911 (in press). 
Culture $\mathrm{Z}$ was a long motile Gram negative bacillus. In a hanging drop preparation a few cells had an enlargement at one end which probably represented spores, although it was impossible to demonstrate their presence by staining reactions. Their survival of an exposure to a temperature of $93.3^{\circ} \mathrm{C}$. $\left(200^{\circ} \mathrm{F}\right.$.) for 30 minutes seemed to affirm the presence of spores. It grew slowly on agar streaks and produced a slimy growth. A 2 days' old culture often showed extremely long types of organisms. Acid was produced in dextrose, galactose, and salicin broths, but not in saccharose, mannite, glycerin, raffinose, inulin, or starch broths. When these broths were used for gas production it was found in one experiment that culture

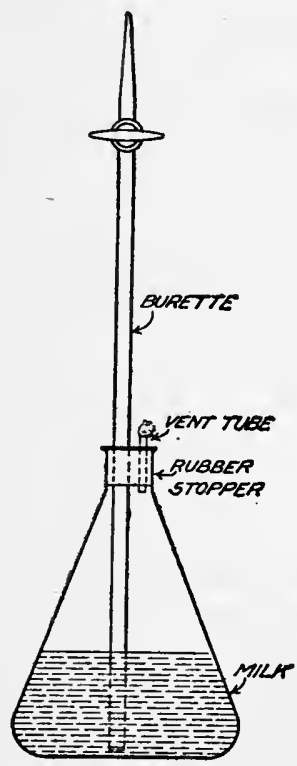

FIG. 25.-Apparatus for the determination of gas production in milk. $\mathrm{Z}$ produced gas in raffinose, mannite, and starch broths after 14 days' incubation at $30^{\circ} \mathrm{C} .\left(86^{\circ} \mathrm{F}\right.$.), but none in any of the other broths. This experiment was repeated and no gas was found in any of the broths. Nitrate solution was reduced and gelatin was not liquefied after 30 days' incubation at $18^{\circ} \mathrm{C} .\left(64.4^{\circ} \mathrm{F}\right.$.). This culture produced acid and gas in milk and coagulated it after 14 days. The ability to produce gas in milk through a long period is one of the striking characteristics of this organism. In order to determine how long culture $\mathrm{Z}$ would continue to produce gas in milk, a 25 cubic centimeter burette was inverted and inserted through a rubber cork into an Erlenmeyer flask containing 200 cubic centimeters of milk, as shown in figure 25. By opening the stopcock of the burette the milk could be drawn to the top and the tube filled. After sterilizing, the milk was inoculated with culture $\mathrm{Z}$ and incubated at $30^{\circ} \mathrm{C}$. $\left(86^{\circ} \mathrm{F}.\right)$. The gas produced was recorded daily and when the burette was filled with gas the stopcock was opened and the tube was again filled with milk. In that way it was possible to record gas production from milk over an indefinite period. As may be seen from figure 26, this organism was able to produce gas through a period of 46 days. The fermentation began after 24 hours' incubation when from 3 to 4 cubic centimeters of gas was formed daily until the fourteenth day, when the milk was curdled. At that time the daily gas production increased and was sometimes as high as 15 cubic centimeters. The increased gas production continued until the thirty-first day, when it was reduced to approximately 4 cubic centimeters per day. The gas produced was hydrogen and carbon dioxide. The ability of culture 
$\mathrm{Z}$ to produce gas in milk continuously for a long period, together with the fact that while gas was formed in milk lactose in broth was not fermented, differentiates this organism from the ordinary types of gas formers. A more extended study of this type of organism is under way in the research laboratories of this division.

The survival of pasteurization by gas-forming bacteria is of considerable importance, since it has been suggested to make the presence of the colon group an indication of recontamination of pasteur-

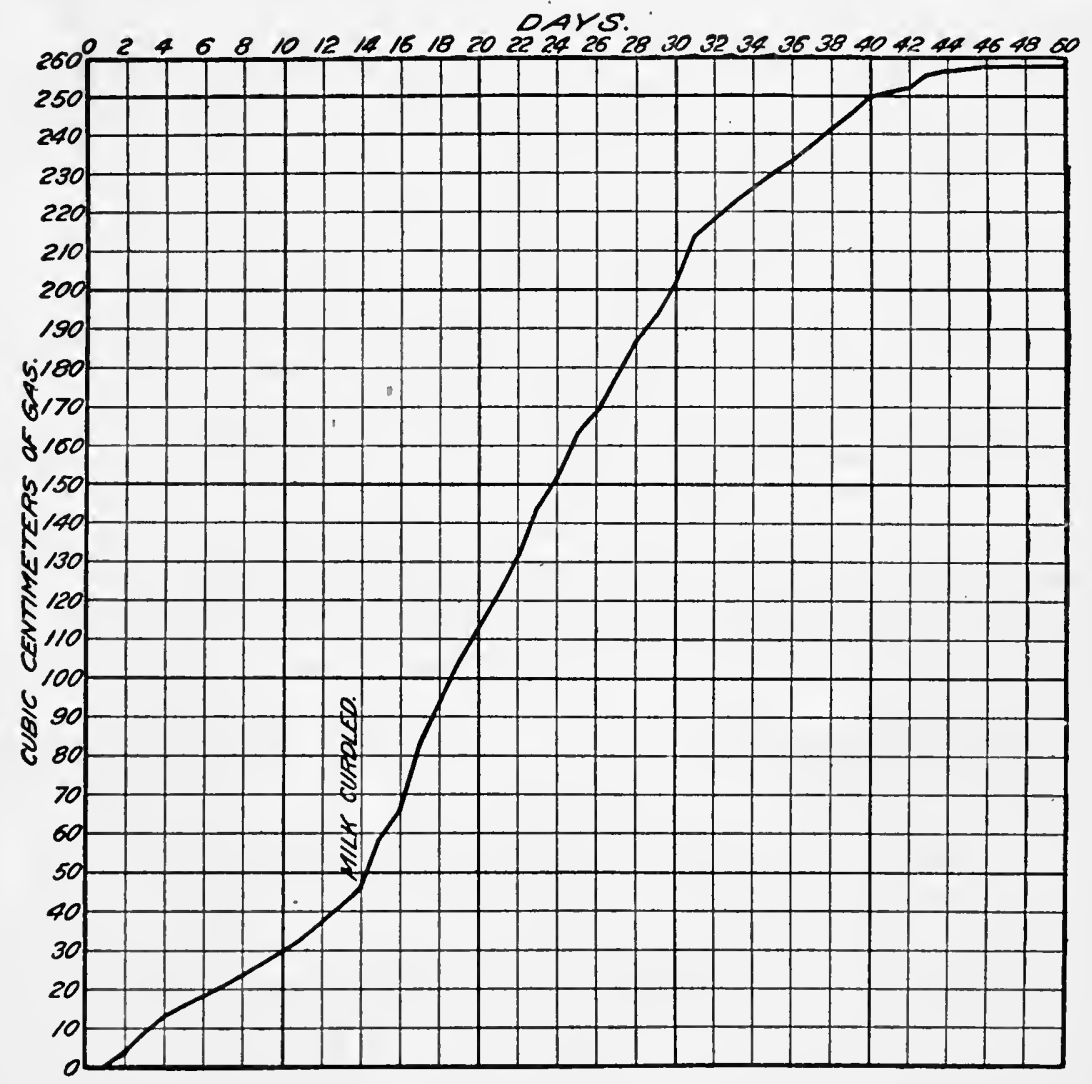

FIG. 26.-Gas produced by culture 7 .

ized milk or of inefficient pasteurization. Several boards of health are at present using such a test. If gas-forming organisms do not survive pasteurization, then of course their presence in pasteurized milk means recontamination or inefficient pasteurization. If, however, certain types of gas-forming bacteria do survive the process, then the test is of no value. In order to determine if gas-forming bacteria survived pasteurization for 30 minutes at $62.8^{\circ} \mathrm{C} .\left(145^{\circ} \mathrm{F}\right.$.), 19 samples of raw milk were heated in sterile flasks. Fermentation 
tubes in sets of four were then inoculated with 1 cubic centimeter and 5 cubic centimeters of both the raw and the pasteurized milk. The results are shown in Table 18. Twelve of the samples of raw milk showed the presence of gas-forming organisms in lactose bile tubes when 1 cubic centimeter of milk was used for inoculation. After pasteurization three samples showed gas when 1 cubic centimeter was used and eight samples when 5 cubic centimeters of milk was used. When dextrose liver broth fermentation tubes were used, a larger number of samples of the pasteurized milk showed the presence of gas-forming bacteria. It may be seen from the table that the number of gas producers in the raw and pasteurized milk was low as determined by the dilution and the number of tubes of each set of four which showed gas. For example, sample 1, four tubes of lactose bile, each inoculated with 1 cubic centimeter of raw milk, showed no gas, which means that no gas-forming organisms were present in 4 cubic centimeters of the raw milk. Four tubes, each inoculated with 5 cubic centimeters of the same milk pasteurized, showed gas in two tubes. That means at least one gas-forming organism in every 10 cubic centimeters of the milk.

TABI.E 18.-Gas production in lactose-bile and dextrose-liver broths inoculated with raw milk and mill pasteurized at $65.8^{\circ} \mathrm{C} .\left(145^{\circ} \mathrm{F}\right.$.) for 30 minutes. Four tubes used in each dilution.

\begin{tabular}{|c|c|c|c|c|c|c|}
\hline \multirow{3}{*}{$\begin{array}{l}\text { Sample } \\
\text { num- } \\
\text { ber. }\end{array}$} & \multicolumn{6}{|c|}{ Gas produced in- } \\
\hline & \multicolumn{3}{|c|}{ Lactose-bile broth. } & \multicolumn{3}{|c|}{ Dextrose-liver broth. } \\
\hline & $\begin{array}{c}\text { Inocu- } \\
\text { lated } \\
\text { with } 1 \\
\text { c. c. raw } \\
\text { milk. }\end{array}$ & $\begin{array}{l}\text { Inocu- } \\
\text { lated } \\
\text { with } 1 \\
\text { c. c. pas- } \\
\text { teur- } \\
\text { ized } \\
\text { milk. }\end{array}$ & $\begin{array}{l}\text { Inocu- } \\
\text { lated } \\
\text { with } 5 \\
\text { c. c. pas- } \\
\text { teur- } \\
\text { ized } \\
\text { milk. }\end{array}$ & $\begin{array}{c}\text { Inocu- } \\
\text { lated } \\
\text { with } 5 \\
\text { c. c. raw } \\
\text { milk. }\end{array}$ & $\begin{array}{c}\text { Inocu- } \\
\text { lated } \\
\text { with } 1 \\
\text { c. c. pas- } \\
\text { teur- } \\
\text { ized } \\
\text { milk. }\end{array}$ & $\begin{array}{l}\text { Inocu- } \\
\text { lated } \\
\text { with } 5 \\
\text { c. c. pas- } \\
\text { teur- } \\
\text { ized } \\
\text { milk. }\end{array}$ \\
\hline $\begin{array}{r}1 \\
2 \\
3 \\
4 \\
5 \\
6 \\
7 \\
8 \\
9 \\
10 \\
11 \\
112 \\
13 \\
14 \\
15 \\
16 \\
17 \\
18\end{array}$ & \begin{tabular}{c} 
Tubes. \\
0 \\
0 \\
0 \\
3 \\
0 \\
3 \\
3 \\
0 \\
2 \\
2 \\
1 \\
\hdashline.. \\
4 \\
3 \\
1 \\
4 \\
4
\end{tabular} & $\begin{array}{c}\text { Tubes. } \\
0 \\
0 \\
0 \\
0 \\
0 \\
0 \\
0 \\
0 \\
0 \\
0 \\
0 \\
0 \\
0 \\
0 \\
3 \\
2 \\
0\end{array}$ & \begin{tabular}{|c|} 
Tubes. \\
2 \\
0 \\
0 \\
1 \\
0 \\
3 \\
1 \\
0 \\
0 \\
0 \\
0 \\
0 \\
0 \\
0 \\
1 \\
4 \\
0 \\
4
\end{tabular} & $\begin{array}{c}\text { Tubes. } \\
0 \\
0 \\
0 \\
1 \\
3 \\
3 \\
3 \\
0 \\
0 \\
0 \\
0 \\
\cdots \\
3 \\
4 \\
2 \\
4 \\
4\end{array}$ & $\begin{array}{c}\text { Tubes. } \\
3 \\
3 \\
1 \\
0 \\
0 \\
0 \\
0 \\
0 \\
0 \\
0 \\
3 \\
0 \\
1 \\
0 \\
1 \\
2 \\
0\end{array}$ & $\begin{array}{c}\text { Tubes. } \\
2 \\
2 \\
0 \\
1 \\
2 \\
2 \\
1 \\
2 \\
2 \\
0 \\
2 \\
0 \\
4 \\
0 \\
1 \\
2 \\
2\end{array}$ \\
\hline 19 & 3 & $i$ & 4 & & & \\
\hline
\end{tabular}

Milk incubated at $37^{\circ} \mathrm{C}$. for 18 hours and then pasteurized.

Litmus lactose agar plates were made and inoculated from almost every sample which showed gas in the bile tubes, but no organisms of the colon type were found. The only gas producer which was 
found was a spore-forming anaerobic bacillus of the butyric group. One of these organisms, known as culture T, produced acid in dextrose, galactose, saccharose, raffinose, and starch broths, and gas in dextrose, galactose, lactose, saccharose, and starch broths. In this work no organisms of the colon group were found to survive pasteurization, but gas was often produced in lactose bile tubes inoculated with pasteurized milk. The gas production, however, was not due to organisms of the colon group, but to those of the butyric-acid group. This anaerobic butyric bacillus produced gas in lactose bile tubes and would appear in the preliminary tests for the colon bacillus. Therefore, if only lactose bile fermentations were used to determine the presence of the colon group in pasteurized milk, the anaerobic butyric types of bacteria would produce fermentations which would be taken as an indication of the colon group. It is evident, then, that the presence of the colon group of organisms in milk must be determined by something more than simply lactose bile fermentation tubes. 'These results are by no means conclusive, for if a larger number of samples had been examined colon bacilli might have been found which survived pasteurization. De Jong and De Graaff, ${ }^{1}$ working on various strains of Bacillus coti, found some forms which required 30 minutes heating at $70^{\circ}-72^{\circ}$ C. $\left(158^{\circ}-161.6^{\circ} \mathrm{F}\right.$.) to destroy. Zelenski ${ }^{2}$ also found some strains of $B$. coli which resisted high temperatures. Evidently resistant types of the colon group do exist and that fact complicates the value of the colon test for reinfection of pasteurized milk.

\section{THERMAL DEATH POINTS OF BACTERIA. WHICH SURVIVE PASTEURIZATION.}

As a matter of purely scientific interest the thermal death points of several bacteria which survived pasteurization were determined. The determinations were made by heating 2 days' old lactose dibasic broth cultures for 30 minutes in Sternberg bulbs. After heating, the contents of the bulbs were inoculated into litmus milk tubes. Cultures were selected from the acid, alkali, and peptonizing groups for the experiment. The results are shown in Table 19. Culture 40 of the acid group stood as high as $79.4^{\circ} \mathrm{C} .\left(175^{\circ} \mathrm{F}\right.$.). Numbers 58 and 156 were destroyed at $73.9^{\circ} \mathrm{C}$. $\left(165^{\circ} \mathrm{F}\right.$.) and culture 81 at $65.6^{\circ} \mathrm{C}$. $\left(150^{\circ} \mathrm{F}\right.$.). Ono culture of the alkali group was destroyed at $65.6^{\circ} \mathrm{C}$. $\left(150^{\circ} \mathrm{F}.\right)$. Culture 450 of the peptonizing group was destroyed at $71.1^{\circ} \mathrm{C}$. $\left(160^{\circ} \mathrm{F}\right.$.), while the thermal death point of culture 456 was indefinite, although about $79.4^{\circ} \mathrm{C} .\left(175^{\circ} \mathrm{F}\right.$.).

I De Jong, D. A., and De Graafr, W. C. Die Coli-Kontrolle der pasteurisierten Milch. Wederlandsch Weekblad voor Zuivelbereiding en Veeteelt, vol. 12, Nos. 37 and 38, 1906). A bstract: Milcliwirtschaftliehes Zentralblatt, vol. 3, No. 6, pp. 26is-268. Leipzig, June, 1907.

2 Zelenski, Thaddeus. Zur Frage der I'asteurisation der sïuglingsmilch. Jahrbuch für Kinderheilkunde, vol. 63, pp. 285-307. Berlin, 1906. $\Lambda$ bstract: Centralblatt für liakteriologie, l'arasitenkunde und. Infektionskrankheiten. Abteilung 2, vol. 18, No. 4-6, p. 175. Jena, Mar. 14, 1907. 
TABLE 19.-Thermal death point of bacteria surviving pasteurization.

\begin{tabular}{|c|c|c|c|c|c|c|c|c|c|}
\hline \multirow[b]{2}{*}{ Culture. } & \multicolumn{9}{|c|}{30 minutes in Sternberg bulbs at - - } \\
\hline & 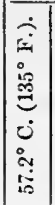 & 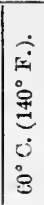 & 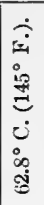 & 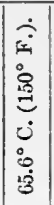 & $\mid \begin{array}{c}\dot{P} \\
0 \\
0 \\
0 \\
0 \\
0 \\
0 \\
0 \\
0 \\
\dot{B}\end{array}$ & 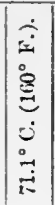 & 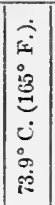 & 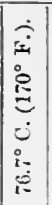 & 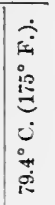 \\
\hline ACID GROUP. & & & & & & & & & \\
\hline $\begin{array}{l}\text { Culture } 40 \ldots \\
\text { Culture } 81\end{array}$ & & $\cdots$ & 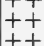 & $\begin{array}{l}x^{\prime} \\
++ \\
++\end{array}$ & $\begin{array}{l}++ \\
++ \\
+\end{array}$ & $\begin{array}{ll}2 \\
+ \\
++ \\
+\end{array}$ & + & $+\overline{+}$ & \pm \\
\hline Culture $156 \ldots . .$. & & $\cdots$ & +7 & ++ & ++ & ++ & - & -- & - \\
\hline ALKALI GROUP. & & & & & & & & & \\
\hline PEPTONIZING GROUP. & ++ & ++ & ++ & -- & $-\infty$ & --1 & --1 & & \\
\hline $\begin{array}{l}\text { Culture } 450 \ldots \\
\text { Culture } 4506 \ldots\end{array}$ & $\begin{array}{l}++ \\
++\end{array}$ & & $\begin{array}{ll}+ \\
++ \\
++\end{array}$ & $\begin{array}{l}++ \\
++\end{array}$ & +- & -1 & -- & +- & \\
\hline
\end{tabular}

In one sample of milk heated at $82.2^{\circ} \mathrm{C} .\left(180^{\circ} \mathrm{F}\right.$.) for 30 minutes it was found by the tube method of group differentiation that a very large percentage of the acid group survived. Sixty-four milk cultures of the resistant acid bacteria were examined roughly for their thermal death point by inoculating fresh litmus milk tubes with one drop of the milk culture. One set of milk tubes was then heated for 30 minutes at $87.8^{\circ} \mathrm{C} .\left(190^{\circ} \mathrm{F}\right.$.) in a water bath and another set at $93.3^{\circ} \mathrm{C}$. $\left(200^{\circ} \mathrm{F}\right.$. $)$ for the same length of time. Of the 64 tubes heated at $87.8 \mathrm{C}$. $\left(190^{\circ} \mathrm{F}\right.$.) 27 showed growth, but all were destroyed at $93.3^{\circ} \mathrm{C} .\left(200^{\circ} \mathrm{F}\right.$.). These heat-resistant acid-forming organisms are of great importance in connection with the pasteurization of milk. From a purcly scientific standpoint they are of interest, since in general the thermal death point of vegetative cells has been believed to be below $60^{\circ} \mathrm{C}$. $\left(140^{\circ} \mathrm{F}\right.$.). From the numbers of these heat-resistant organisms it is evident that they are not u:common in milk.

\section{THE POSSIBLE USE IN PASTEURIZATION OF ACID-FORMING BACTERIA OF HIGH THERMAL DEATH POINT.}

Since certain strains of typical lactic-acid bacteria are known to be able to withstand pasteurizing temperatures, it seems possible to make use of their resistance. It has been suggested that cultures of lactic-acid bacteria be added to milk after pasteurization in order to insure a normal souring. A process of that nature would necessarily involve a danger of contamination by pathogenic bacteria from employees at the dairy, since the acid-forming bacteria are to be added after the heating process. By the use of a lactic-acid organism of high thermal death point it would be possible to add the culture to the 
raw milk and then pasteurize. One experiment was tried to show this point. As may be seen from Table 20, a sample of certified milk was divided into two parts of 800 cubic centimeters each. Both portions were heated in sterile flasks for 30 minutes at $62.8^{\circ} \mathrm{C}$. $\left(145^{\circ} \mathrm{F}\right.$.). To one flask 5 cubic centimeters of a high-temperature resistant lacticacid culture was added before pasteurization. The effect of the addition of the culture can be seen by the change in the milk when held at room temperature. After four days the milk without the culture was curdled with a rennet curd and was partly peptonized, very little acid having developed. The other sample to which the heat resistant eulture was added was curdled on the fourth day and showed a smooth firm acid eurd with no digestion. By the addition of the culture before pasteurization in sealed bottles subsequent infection would be impossible. This possibility of addition of high temperature resistant lactic-acid bacteria is merely suggested for those who advocate the addition of cultures after pasteurization.

TABLE 20.-Change in acid development in pasteurized milk produced by the addition of high-temperature resisting lactic-acid bacteria previous to pasteurization.

PER CENT LACTIC ACID.

[Samples held at room temperature, $21.1^{\circ}-23.9^{\circ} \mathrm{C}$. $\left(70^{\circ}-75^{\circ} \mathrm{F}.\right)$.]

\begin{tabular}{|c|c|c|c|c|c|}
\hline & \multicolumn{5}{|c|}{ Lactic acid after- } \\
\hline . & $\begin{array}{c}0 \\
\text { day. }\end{array}$ & $\begin{array}{c}1 \\
\text { day. }\end{array}$ & $\stackrel{2}{\text { days. }}$ & däys. & $\stackrel{4}{4}$ \\
\hline 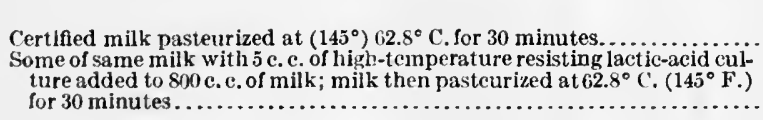 & Perct. & $\mid \begin{array}{c}\text { Perct. } \\
0.17 \\
.17\end{array}$ & Perct. & Perct. & $\begin{array}{l}\text { Perct. } \\
\text { 10.31 } \\
2.50\end{array}$ \\
\hline
\end{tabular}

1 Curdled and peptonized.

2 Curdled, acid curd.

\section{QUALITATIVE STUDY OF THE COMPLETE BACTERIAL FLORA OF} ONE SAMPLE OF PASTEURIZED MILK.

Since in the qualitative study of the bacteria surviving pasteurization a few typical cultures representing each group were selected from each sample, it was thought advisable to make a more thorough qualitative study of the bacteria in one sample of pasteurized milk.

The complete bacterial flora of one sample of milk pasteurized for 30 minutes at $60^{\circ} \mathrm{C} .\left(140^{\circ} \mathrm{F}\right.$.) and another portion of the same milk pasteurized at $65.6^{\circ} \mathrm{C}$. $\left(150^{\circ} \mathrm{F}\right.$.) were studied qualitatively.

Litmus lactose gelatin plates were made, and after 6 days' incubation at $18^{\circ} \mathrm{C}$. $\left(64.4^{\circ} \mathrm{F}\right.$.) each colony was picked off, purified by plating, and studied. The A series of cultures is made up of 176 cultures picked from a plate from milk pasteurized at $60^{\circ} \mathrm{C} .\left(140^{\circ} \mathrm{F}\right.$.). The B series is composed of 92 cultures from a plate from milk pasteurized at $65.6^{\circ}\left(150^{\circ} \mathrm{F}\right.$.). Each series has been divided into five 


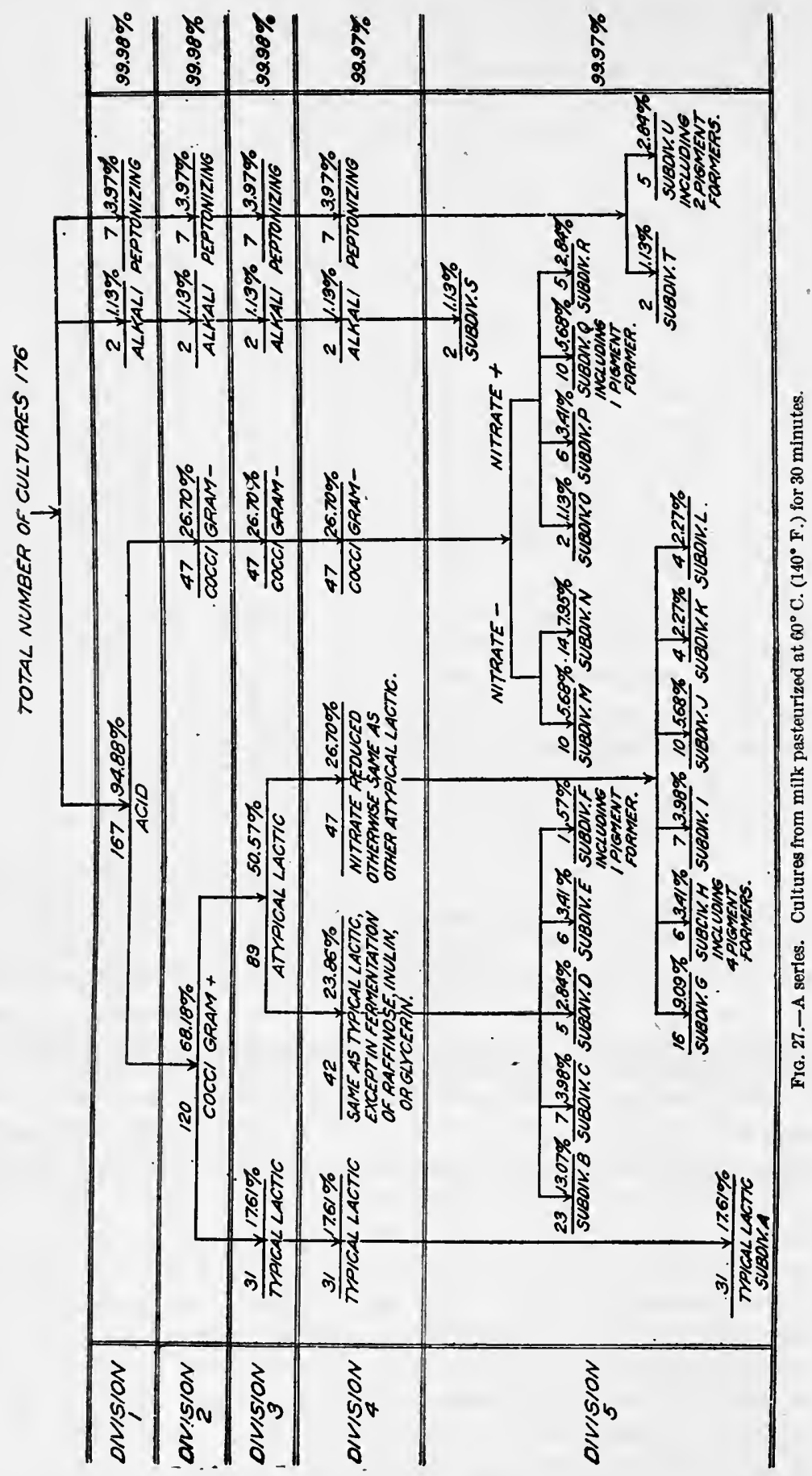


divisions according to the differentiation of the bacteria. Table 21 shows the A series. Division 1, figure 27, shows the division of the 176 cultures of bacteria which survive pasteurization at $60^{\circ} \mathrm{C}$. $\left(140^{\circ} \mathrm{F}\right.$.) into three groups-the acid, the alkali, and the peptonizing group.

Per cent.

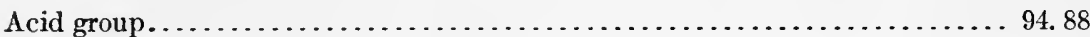

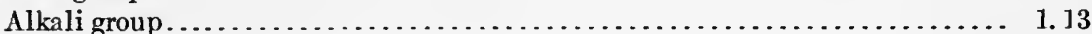

Peptonizing group.................................... 3.97

In division 2 the acid group has been further divided as shown and the percentages given. Each division shows the complete percentages of the various classes. Division 5 shows the final classification and percentages. Each subdivision of division 5 has been given a letter which makes it possible by the use of the following key to determine the complete reactions of the bacteria in each subdivision:

KEY TO LETTERS AND SIGNS USED IN FORMULA SHOWING CULTURAL REACTIONS OF THE SUBDIVISIONS.

The formula reads in the order of the numerals:

B. B-Bacilli.

C-Cocci.

2. A-Gelatin not liquefied.

$\mathrm{X}-$ Gelatin liquefied.

$\mathrm{X}_{1}-1-10 \mathrm{~mm}$. of liquefaction.

$\mathrm{X}_{2}$-over $10 \mathrm{~mm}$. of liquefaction.

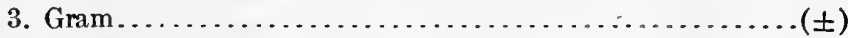

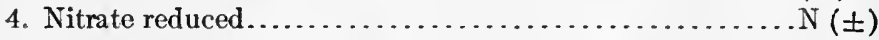

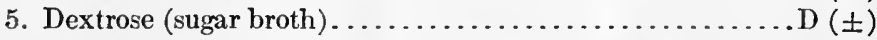

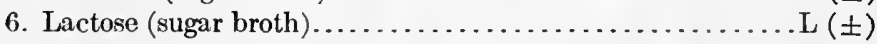

7. Saccharose (sugar broth) $\ldots \ldots \ldots \ldots \ldots \ldots \ldots \ldots \ldots \ldots \ldots \ldots \ldots \ldots$

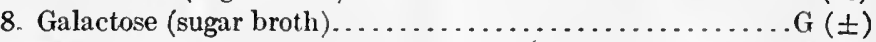

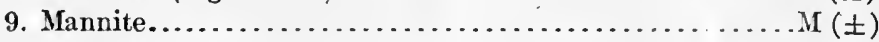

10. Raffinose (sugar broth) $\ldots \ldots \ldots \ldots \ldots \ldots \ldots \ldots \ldots \ldots \ldots \ldots \ldots \ldots \ldots \ldots$

11. Glycerin broth ................................... $( \pm)$

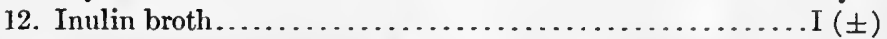

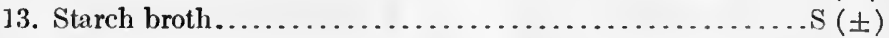

14. Pigment production..........................

The formulas of the reactions of the subdivisions are given in Table 21. 


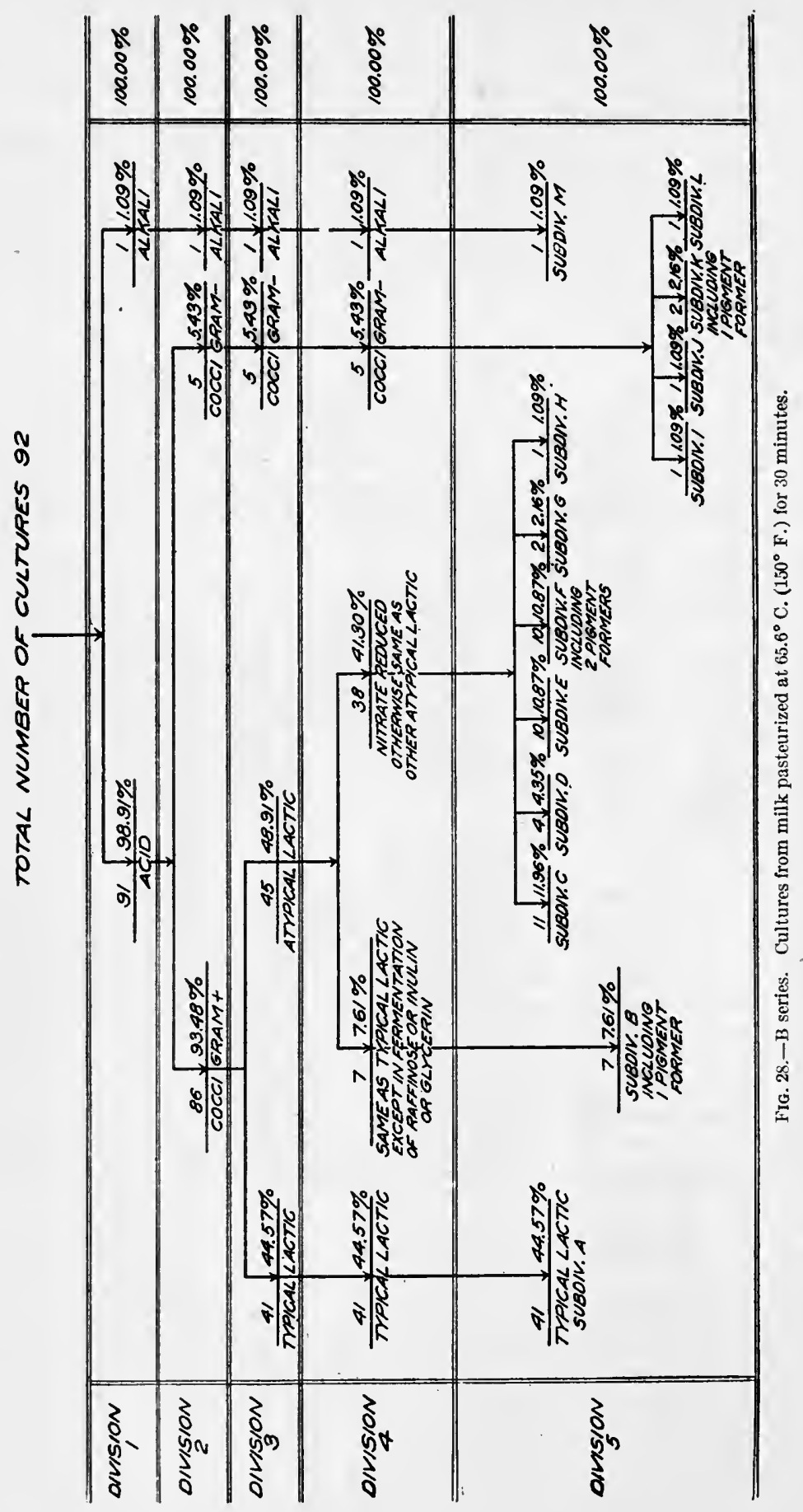


TABLE 21.-Cultural reactions of organisms in subdivisions-cultures of $\boldsymbol{A}$ series from milk pasteurized for 30 minutes at $60^{\circ} \mathrm{C} .\left(140^{\circ} \mathrm{F}\right.$.).

\begin{tabular}{|c|c|}
\hline $\begin{array}{l}\text { Subdivi- } \\
\text { sion. }\end{array}$ & Formula of reactions. \\
\hline $\begin{array}{l}\mathbf{A} \\
\mathbf{B} \\
\mathbf{C} \\
\mathbf{D} \\
\mathbf{E} \\
\mathbf{F} \\
\mathbf{G} \\
\mathbf{H} \\
\mathbf{I} \\
\mathbf{J} \\
\mathbf{K} \\
\mathbf{L} \\
\mathbf{M} \\
\mathbf{N} \\
\mathrm{O} \\
\mathbf{P} \\
\mathbf{Q} \\
\mathbf{R} \\
\mathrm{S} \\
\mathrm{T} \\
\mathrm{U}\end{array}$ & 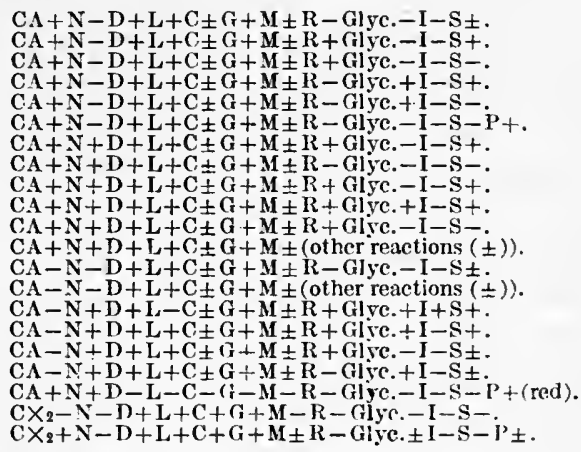 \\
\hline
\end{tabular}

The formula reads as follows, as shown in table:

Subdivision A :

C. Coccus.

A. Gelatin not liquefied.

t. Gramt.

$\mathrm{N}-$. Nitrate not reduced.

D+. Acid produced in dextrose broth.

$\mathrm{L}+$. Acid produced in lactose broth.

$\mathrm{C} \pm$. May or may not produce acid in saccharose broth.

G+. Acid produced in galactose broth.

$\mathrm{M} \pm$. May or may not produce acid in mannite broth.

$\mathrm{R}-$. No acid produced in raffinose broth.

Gly.-. No acid produced in glycerin broth.

I-. No acid produced in inulin broth.

$\mathrm{S} \pm$. May or may not produce acid in starch broth.

The $\mathrm{B}$ series of cultures from milk pasteurized at $65.6^{\circ} \mathrm{C} .\left(150^{\circ} \mathrm{F}\right.$. $)$ were divided in a similar manner as shown in Fig. 28. The formulas of the reactions of the subdivisions are given in Table 22 .

TABLE 22.-Cultural reactions of organisms in subdivisions-cultures of $B$ series from milk pasteurized for 30 minutes at $6.5 .6^{\circ} \mathrm{C} .\left(150^{\circ} \mathrm{F}\right.$.).

\begin{tabular}{|c|c|}
\hline $\begin{array}{l}\text { Subdivi- } \\
\text { sion. }\end{array}$ & Formula of reactions. \\
\hline $\begin{array}{l}\mathbf{A} \\
\text { IB } \\
\mathbf{C} \\
\mathbf{D} \\
\mathbf{E} \\
\mathbf{F} \\
\mathbf{G} \\
\mathbf{I I} \\
\mathbf{I} \\
\mathbf{J} \\
\mathbf{K} \\
\mathbf{L} \\
\mathbf{M}\end{array}$ & 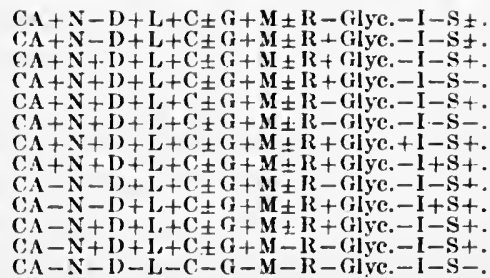 \\
\hline
\end{tabular}


By this system of division one is able to see at a glance the general groups of bacteria which survived pasteurization in one sample of milk heated at $60^{\circ} \mathrm{C} .\left(140^{\circ} \mathrm{F}\right.$. $)$ and $65.6^{\circ} \mathrm{C} .\left(150^{\circ} \mathrm{F}\right.$. $)$. Or if desired, the complete reactions of the various classes of bacteria can be determined. There is little that need be said regarding the results, for they are plainly shown. The most noticeable features were the high percentage of the acid-forming bacteria and the low percentage of the peptonizing group. It may be seen that a large percentage of the acid group were typical lactic acid bacteria as based on the formula of subdivision $\mathrm{A}$.

\section{SUMMARY.}

1. The average temperature used throughout the country with the "holder" process is $62.8^{\circ} \mathrm{C}$. $\left(145^{\circ} \mathrm{F}\right.$.). With the "flash" process, $71.1^{\circ}$ C. $\left(160^{\circ}\right.$ F.).

Reports from 219 milk plants show that 75 used the "holder" and 144 the "flash" process. The range in temperatures is from $60^{\circ} \mathrm{C}$. $\left(140^{\circ} \mathrm{F}\right.$.) to $82.2^{\circ} \mathrm{C}$. $\left(180^{\circ} \mathrm{F}\right.$.). Of the plants using the "holder" process only 1.3 per cent employ temperatures too low for proper pasteurization. Of those which use the "flash" process approximately 42 per cent use temperatures too low to be effective.

2. Percentage bacterial reduction is of no value in determining the efficiency of the process of pasteurization. As a general rule when the bacterial content of raw milk is high there will be a high percentage reduction. When the bacterial content is low, then the percentage reduction is often low. The percentage bacterial reduction may be 99.9 per cent and yet the pasteurized milk may show a count of 100,000 per cubic centimeter. When the pasteurized milk contains only 10,000 bacteria per cubic centimeter the percentage reduction may only have been 95 per cent. It is often impossible to obtain a 99 per cent reduction when a good quality of milk is pasteurized, therefore regulations which require a 99 per cent reduction of bacteria during pasteurization are of no value.

3. A heating period of three hours causes a marked increase in the reduction of bacteria in milk over one-half hour's heating, when a temperature of $54.4^{\circ} \mathrm{C} .\left(130^{\circ} \mathrm{F}\right.$. $)$ and $57.2^{\circ} \mathrm{C} .\left(135^{\circ} \mathrm{F}\right.$. $)$ are used. At $60^{\circ} \mathrm{C}$. $\left(140^{\circ} \mathrm{F}\right.$.) the increased reduction is much less. According to the results of one experiment in this investigation, a six hours' period of heating at $62.8^{\circ} \mathrm{C} .\left(145^{\circ} \mathrm{F}\right.$.) does not produce any more destruction of baeteria than does one-half hour's heating.

4. Sudden cooling from $62.8^{\circ} \mathrm{C} .\left(145^{\circ} \mathrm{F}\right.$.) or $71.1^{\circ} \mathrm{C} .\left(160^{\circ} \mathrm{F}\right.$.) within 15 seconds to from $1.7^{\circ}-3.9^{\circ} \mathrm{C}$. $\left(35^{\circ}-39^{\circ} \mathrm{F}\right.$.) does not cause any destruction of bacteria. The long-prevailing idea that sudden cooling is an essential part of the process of pasteurization is erroneous so far as any increased destruction of bacteria is concerned. Its 
value lies only in the fact that milk suddenly cooled is not allowed to stand at temperatures between $37.8^{\circ} \mathrm{C}$. $\left(100^{\circ} \mathrm{F}\right.$.) and $10^{\circ} \mathrm{C}$. $\left(50^{\circ} \mathrm{F}\right.$.), where rapid bacterial development might occur.

5. Four distinct groups of bacteria, the acid-forming, the inert, the alkali-forming, and the peptonizing, survive pasteurization, as differentiated by their reactions in litmus milk after 14 days' incubation at $30^{\circ} \mathrm{C} .\left(86^{\circ} \mathrm{F}\right.$. $)$.

The percentage of the acid group is increased by pasteurization while the other groups are decreased in their percentage of the total bacteria. The average percentage of lactic acid bacteria in raw milk which survive pasteurization for 30 minutes at $62.8^{\circ} \mathrm{C}$. $\left(145^{\circ} \mathrm{F}\right.$.) ranges from 1.27 per cent to 4.55 per cent in the various grades of milk.

When the temperature of pasteurization is below $76.7^{\circ} \mathrm{C} .\left(170^{\circ} \mathrm{F}\right.$.) the bacterial flora of milk is composed for the most part of organisms of the acid group. At temperatures above $76.7^{\circ} \mathrm{C}$. $\left(170^{\circ} \mathrm{F}\right.$.) the acid group is largely destroyed and the majority of the bacteria which survive are of the peptonizing type. These bacterial group relations are clearly shown in the figures in the conclusions.

6. When different grades of milk are pasteurized at $62.8^{\circ} \mathrm{C}$. $\left(145^{\circ} \mathrm{F}\right.$.) in the laboratory and held at room temperature the bacterial flora may undergo three distinct changes. First, when a fair quality of milk is pasteurized the acid group may develop at once and overgrow all the other groups, forming acid and producing a normal curd. Second, when a poor quality of milk is pasteurized the peptonizing group may grow rapidly at first along with the acid group, which later overgrows them. In this case the milk will first become curdled with a rennet curd due to the peptonizing bacteria, then later will become sour from the development of the lactic-acid group of organisms. Third, when a good grade of milk is pasteurized the peptonizing bacteria may overgrow the acid group of organisms so that the milk becomes peptonized without the development of any acid. These same grades of milk, treated in the same manner but held in an ice chest at $10^{\circ} \mathrm{C}$. $\left(50^{\circ} \mathrm{F}\right.$.), show entirely different changes in their bacterial contents. The growth of the peptonizing group is restrained so that they are of little importance. The percentage of the acid group remains about the same through a long period. Occasionally the percentage of the alkali group may increase after five days, but eventually the acid group forms the major group. These results were obtained from laboratory experiments and only indicate possible changes in the bacterial flora of pasteurized milk when held at different temperatures. They show the delicate balance between the bacterial groups, but can not be applied to indicate the bacterial changes in milk pasteurized and handled under commercial conditions. 
7. A qualitative study of the acid group shows that many organisms giving characteristics of the typical lactic-acid bacteria survive pasteurization for 30 minutes at $62.8^{\circ} \mathrm{C}$. $\left(145^{\circ} \mathrm{F}\right.$.). Other lacticacid forming bacteria survive which may form pigment or vary from the typical lactic types in the fermentative reactions.

The inert group was made up of organisms which produce no change in litmus milk during 14 days' incubation, and therefore include many which did not grow, but which according to the method of differentiation would be included as inert forms. The only truly inert form recognized was a yellow pigment-forming organism. The inert group is probably of little importance.

The alkali group which survive pasteurization is of importance. Bacteria of this group can not be differentiated from those of the inert group or from slow acid-forming organisms by plating, but are easily determined by the milk-tube method. They grow at low temperatures and produce a strong alkaline reaction in milk. In pure cultures enough alkali is produced to dissolve the casein. No acid is produced in fermentation broths, but often an alkaline reaction is found.

The peptonizing group includes those organisms which peptonize casein. A number of the organisms isolated peptonized casein, but did not liquefy gelatin. Various types of this group are able to survive pasteurization and vary widely in their cultural characteristics.

The few gas-forming bacteria in pasteurized milk, so far as the results of this investigation indicate, do not include organisms of the colon-aerogenes group. One gas-forming organism was found which produced gas in milk and peptonized casein. Another culture, known as $\mathrm{Z}$, seems to be an entirely new type, which is characterized by its ability to produce gas continuously in milk through a long period, and by the fact that while gas is formed in milk none is formed in lactose broth.

Gas-forming anaerobic bacteria are often found in milk which produce gas in lactose bile tubes and which might be mistaken in a preliminary test for the colon organism.

8. In view of the fact that gas-forming organisms survive pasteurization which will give the preliminary test for the colon organism by the lactose bile fermentation-tube method, it seems advisable to suggest that boards of health which depend on the presence of the colon-aerogenes group as an indication of reinfection or inefficient pasteurization make a complete determination by cultural reactions of organisms suspected as being colon forms.

9. The thermal death point of one lactic acid organism isolated during this investigation was $79.4^{\circ} \mathrm{C}$. $\left(175^{\circ} \mathrm{F}\right.$.) when a broth culture was heated in Sternberg bulbs for 30 minutes. The thermal death points of 64 acid-forming bacteria from one sample of milk which 
survived pasteurization for 30 minutes at $82: 2^{\circ}$ C. $\left(180^{\circ} \mathrm{F}\right.$.) determined roughly was between $82.2^{\circ} \mathrm{C} .\left(180^{\circ} \mathrm{F}\right.$.) and $93.3^{\circ} \mathrm{C} .\left(200^{\circ} \mathrm{F}\right.$. $)$.

10. Only a small percentage of spore-forming bacteria are found in milk pasteurized for 30 minutes at $62.8^{\circ} \mathrm{C}$. ( $145^{\circ} \mathrm{F}$.). Of $225 \mathrm{cul}-$ tures selected at random which were studied, only 3 , or 1.35 per cent, formed spores.

11. For those who advocate the inoculation of pasteurized milk after heating, with a culture of lactic acid bacteria to produce a normal souring, it is suggested that a culture of a high-temperature resisting lactic-acid organism may be added before pasteurization. By such a method there would be no danger of infection as might result accidentally by inoculation after pasteurization.

12. In view of the results of this investigation it seems that the control of pasteurization should be maintained by bacterial limits for the milk to be pasteurized, together with supervision which will insure the use of the proper pasteurizing temperature and guard against reinfection. A bacterial standard then need not be set for pasteurized milk.

\section{CONCLUSIONS.}

The results in this paper are based upon laboratory experiments performed under conditions which made reinfection impossible. The bacteria which survived pasteurization, therefore, represent those bacteria which could not be destroyed at the temperature of pasteurization. A temperature of $62.8^{\circ} \mathrm{C} .\left(145^{\circ} \mathrm{F}\right.$.) for 30 minutes was used in most of the experiments, since that is the most universally used temperature with the "holder" process in this country. Higher temperatures, however, were also used in order to show the changes in the bacterial groups which survived. From the results of the work it has been possible to show graphically in figure 29 the hypothetical relations of the bacterial groups in raw milk and milk pasteurized by the "holder" process at various temperatures under laboratory conditions. The bacterial flora of the various kinds of milk is represented by columns of equal length divided into sections, which represent in a general way the relative size of the bacterial groups.

From the figure it may be seen that raw milk contains four principal groups of bacteria - the acid, the inert, alkali, and peptonizing groups. The acid group is divided in to two groups-the acid-congulating, which coagulates milk in less than 14 days, and the acid group, which merely produces acid and does not coagulate milk inside of 14 days. In raw milk the inert group is the largest. In milk pasteurized at $62.8^{\circ} \mathrm{C} .\left(145^{\circ} \mathrm{F}\right.$.) the great increase in the proportion of the acid-coagulating and acid groups is plainly shown. The percentage of the alkali and peptonizing groups are reduced. At $71.1^{\circ} \mathrm{C}$. $\left(160^{\circ} \mathrm{F}\right.$.) the total acid group is still the largest, but 
the acid coagulating group is made up of bacteria which coagulate very slowly. At this temperature the alkali group is greatly reduced and the peptonizing reduced to the minimum. At $76.7^{\circ} \mathrm{C} .\left(170^{\circ} \mathrm{F}\right.$.) the total acid group remains about the same, but the organisms produce acid and coagulate very slowly. The alkali group is practically

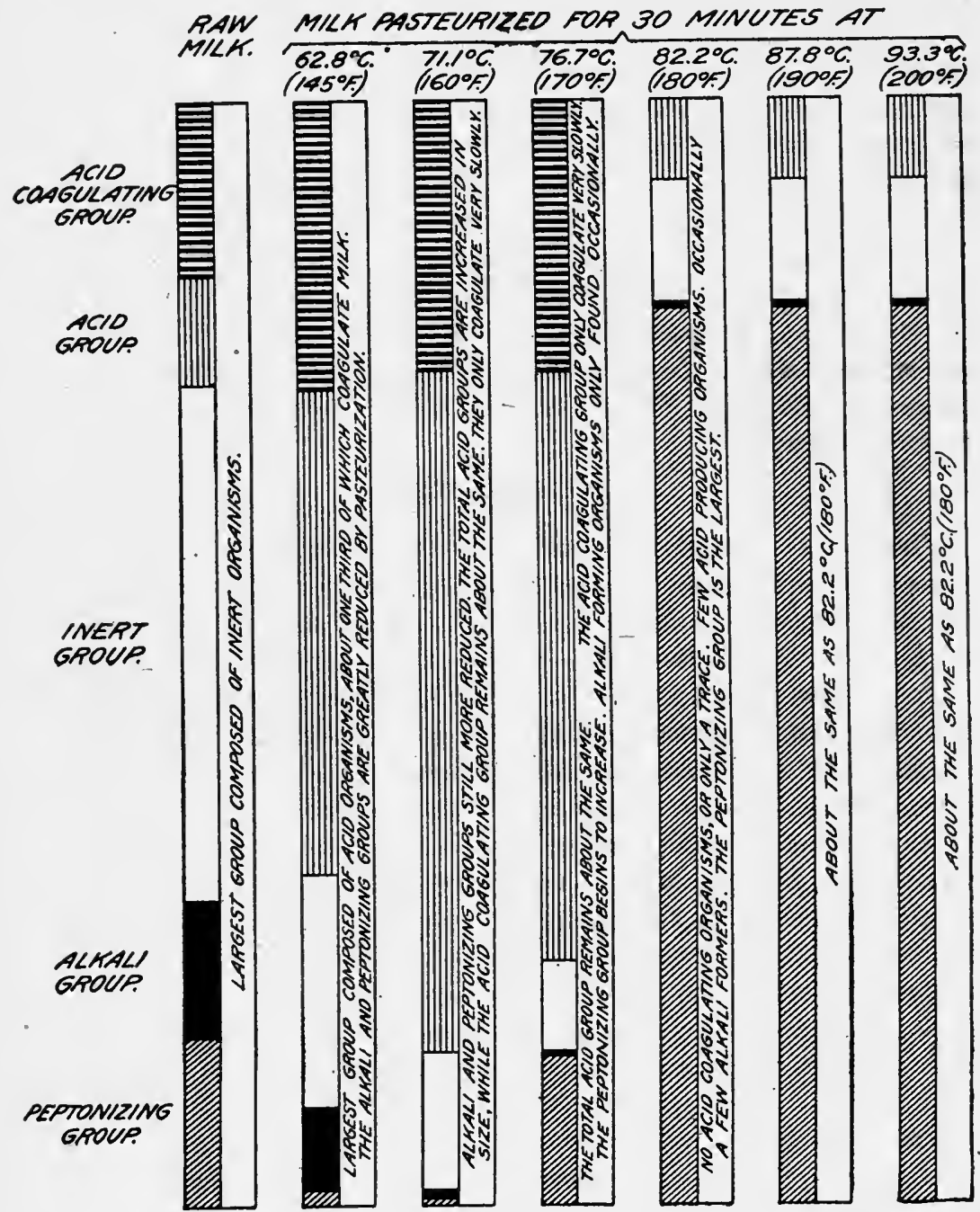

FIG. 29.-The hypothetical relation of the bacterial groups to raw and pasteurized milk.

destroyed, although occasionally a sample may show a fairly high percentage. The most important change is in the peptonizing group. At this temperature the percentage of the peptonizing group to the total bacteria begins to increase. The increase when milk is pasteurized at $82.2^{\circ} \mathrm{C}$. $\left(180^{\circ} \mathrm{F}\right.$.) is even more striking. At this temperature over 75 per cent of the bacteria which survive are pep- 
tonizers. None of the acid-coagulating group are found and only a small percentage of the acid group. Occasionally a few of the alkali group may be found. At $87.8^{\circ} \mathrm{C} .\left(190^{\circ} \mathrm{F}\right.$.) and $93.3^{\circ} \mathrm{C}$.

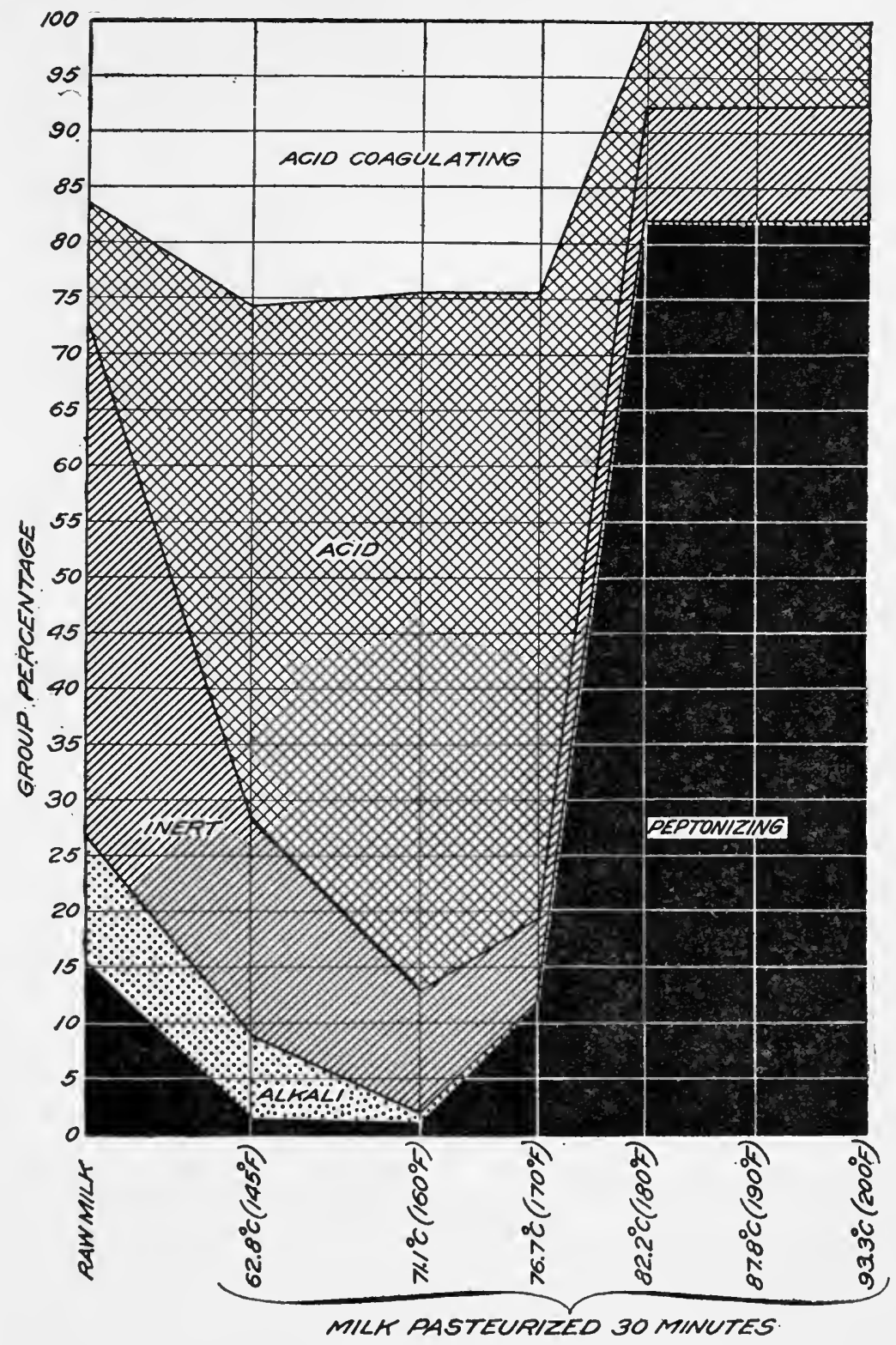

FIG. 30.-The hypothetical relation of the bacterial groups In raw and pasteurized milk.

$\left(200^{\circ} \mathrm{F}\right.$.) the bacterial groups which survive are about the same in their relative sizes as at $82.2^{\circ} \mathrm{C} .\left(180^{\circ} \mathrm{F}\right.$.). The hypothetical relations of the bacterial groups are further shown in figure 30 . The rela- 
tion of the bacterial groups is also shown, which brings out more distinctly, perhaps, the changes in the bacterial groups. Here the reversal of the percentages of the total acid group and the peptonizing group in milk pasteurized above $76.7^{\circ} \mathrm{C}$. $\left(170^{\circ} \mathrm{F}\right.$.) for 30 minutes is plainly shown. It is very evident that when the bacterial flora of pasteurized milk is under discussion the temperature of the process is of fundamental importance. From these figures the bacterial groups in various kinds of milk may be seen at a glance, and they summarize in a very general way the most important results of this investigation. It must be remembered, however, that the relations of the bacterial groups only represent average conditions, and the bacterial flora of every sample of milk must not be expected to conform exactly to these averages. Variations in methods and conditions in the production of milk beyond the control of the investigator may widely influence the bacterial group relations of an individual sample. 
APPENDIX.

TABLE I.-Complete characteristics of the different varieties of acid-forming bacteria which survive pasteurization.

\begin{tabular}{|c|c|c|c|c|c|c|c|c|c|c|c|c|c|c|}
\hline \multirow[b]{2}{*}{ 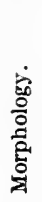 } & \multirow[b]{2}{*}{ 蛋 } & \multirow{2}{*}{ 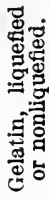 } & \multirow[b]{2}{*}{ 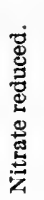 } & \multirow[b]{2}{*}{ 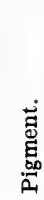 } & \multicolumn{10}{|c|}{ Acid production in- } \\
\hline & & & & & 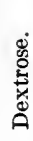 & 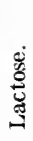 & 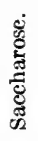 & 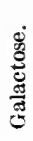 & 起 & 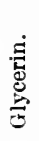 & 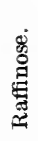 & 息 & $\begin{array}{l}\text { 宽 } \\
\text { 总 }\end{array}$ & 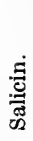 \\
\hline $\mathrm{C}$ & + & - & - & - & + & + & - & + & - & - & - & - & - & - \\
\hline $\mathrm{C}$ & + & - & $\bar{t}$ & - & + & \pm & $=$ & + & $=$ & $\bar{z}$ & $=$ & $=$ & - & $\stackrel{+}{+}$ \\
\hline $\mathrm{C}$ & $+t$ & - & \pm & - & $\begin{array}{l}+ \\
+\end{array}$ & + & - & + & - & $\bar{t}$ & - & $\overline{-}$ & \pm & $\begin{array}{llll}+ \\
+\end{array}$ \\
\hline$\stackrel{\mathrm{C}}{\mathrm{C}}$ & + & $\bar{z}$ & \pm & 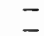 & $\stackrel{+}{+}$ & $\stackrel{+}{+}$ & $\overline{-}$ & $\begin{array}{llll}+ \\
+\end{array}$ & $\bar{z}$ & \pm & $=$ & $=$ & $\bar{z}+x+x+10$ & $\mp$ \\
\hline $\mathrm{C}$ & + & - & + & - & + & $\begin{array}{llll}T & & 0 & 0\end{array}$ & - & $\begin{array}{l}T \\
+\end{array}$ & + & - & - & - & + & I \\
\hline $\mathrm{C}$ & + & - & \pm & - & t & + & + & + & - & - & - & - & - & - \\
\hline $\mathrm{C}$ & + & $\bar{z}$ & \pm & 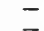 & + & + & + & + & $\bar{z}$ - & - & - & - & + & I \\
\hline$\stackrel{\mathrm{C}}{\mathrm{C}}-(-2)$ & $\stackrel{+}{+}$ & $\overline{-}$ & $\begin{array}{l} \pm \\
\pm\end{array}$ & $\Xi$ & $\stackrel{+}{+}$ & $\stackrel{+}{+}$ & $\stackrel{+}{+}$ & $\stackrel{+}{+}$ & $=$ & $\bar{t}$ & $\Xi$ & $\overline{-}$ & $\overline{-}$ & \pm \\
\hline $\mathrm{C}$ & + & - & - & - & + & + & + & t & - & + & - & - & - & + \\
\hline$\underset{\mathrm{C}}{\mathrm{C}}$ & + & - & $=$ & - & + & + & + & \pm & $=$ & - & + & $\overline{-}$ & - & - \\
\hline $\mathrm{C}$ & + & - & - & - & + & + & + & + & 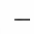 & - & + & $\bar{I}$ & \pm & + \\
\hline $\mathrm{C}$ & + & - & - & - & + & + & + & + & - & - & - & + & + & - \\
\hline $\begin{array}{l}\mathrm{C} \\
\mathrm{C}\end{array}$ & $\stackrel{t}{t}$ & $\bar{z}$ & $\bar{z}$ & $\bar{z}$ & $\stackrel{+}{+}$ & $\stackrel{+}{+}$ & + & $\stackrel{+}{+}$ & $=$ & $\bar{z}$ & \pm & $\stackrel{+}{+}$ & $\stackrel{+}{+}$ & $\bar{t}$ \\
\hline $\mathrm{C}$ & + & - & \pm & - & + & + & + & + & + & - & - & - & + & - \\
\hline${ }_{C}^{C}$ & + & $\bar{z}$ & $\bar{z}$ & $=$ & \pm & + & + & + & + & $\bar{z}$ & - & - & - & + \\
\hline $\begin{array}{l}\mathrm{C} \\
\mathrm{C}\end{array}$ & $\begin{array}{l}+ \\
+\end{array}$ & - & $\bar{t}$ & $I$ & $\begin{array}{l}+ \\
+\end{array}$ & $\stackrel{+}{+}$ & + & $\stackrel{+}{+}$ & $\stackrel{+}{+}$ & $\bar{I}$ & \pm & \pm & $\overline{-}$ & $\bar{z}$ \\
\hline $\mathrm{C}$ & . & - & - & - & + & + & + & + & + & + & + & - & - & + \\
\hline $\mathrm{C}$ & + & + & + & - & + & + & + & + & - & + & - & - & - & - \\
\hline C & + & + & + & $\bar{z}$ & + & $t$ & + & + & - & $\bar{t}$ & $\bar{z}$ & $=$ & $=$ & $\bar{z}$ \\
\hline $\mathrm{C}$ & + & + & - & - & + & + & + & + & + & $I$ & - & - & - & - \\
\hline C & + & - & \pm & + & + & + & - & + & - & - & - & - & - & - \\
\hline$\stackrel{\mathrm{C}}{\mathrm{C}}$ & + & $\bar{z}$ & $=$ & + & $\stackrel{+}{+}$ & $\stackrel{+}{+}$ & $=$ & + & $=$ & $\bar{z}$ & $z$ & $=$ & $\bar{t}$ & \pm \\
\hline $\mathrm{C}$ & + & - & - & + & + & + & - & + & - & - & - & - & + & + \\
\hline C & + & - & + & + & + & + & - & + & - & - & + & - & $-i$ & - \\
\hline C & $t$ & - & $\stackrel{+}{+}$ & + & + & $\stackrel{+}{+}$ & - & + & I & + & - & - & - & - \\
\hline $\begin{array}{l}\mathrm{C} \\
\mathrm{C}\end{array}$ & $\begin{array}{l}+ \\
+\end{array}$ & $\overline{-}$ & $\begin{array}{l}+ \\
\pm\end{array}$ & $\begin{array}{l}+ \\
+\end{array}$ & $\begin{array}{l}+ \\
+\end{array}$ & $\begin{array}{l}+ \\
+\end{array}$ & $\bar{t}$ & $\begin{array}{l}+ \\
+\end{array}$ & \pm & $I$ & z & $\bar{I}$ & \pm & $I$ \\
\hline $\mathrm{C}$ & \pm & - & $=$ & + & + & + & + & + & - & - & - & - & + & - \\
\hline C & + & - & \pm & + & + & + & + & + & - & - & - & - & - & + \\
\hline C & + & - & - & + & + & + & + & $\dot{T}$ & - & - & - & - & + & + \\
\hline $\mathrm{C}$ & + & $=$ & $\bar{T}$ & + & + & + & + & + & $=$ & + & $\overline{-}$ & $\bar{z}$ & \pm & $\bar{z}$ \\
\hline C & + & - & \pm & + & + & + & + & + & - & - & + & - & - & - \\
\hline $\mathrm{C}$ & $\stackrel{+}{t}$ & $=$ & \pm & + & $\stackrel{+}{+}$ & + & + & $\stackrel{+}{+}$ & $\bar{I}$ & \pm & \pm & $\overline{-}$ & $\bar{z}$ & \pm \\
\hline $\mathrm{C}$ & + & - & \pm & + & + & $T$ & + & + & + & - & - & - & + & - \\
\hline 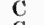 & + & - & - & + & + & + & + & + & + & - & - & - & - & + \\
\hline${ }_{C}^{\mathrm{C}}$ & + & - & + & + & + & + & + & + & + & - & - & - & + & + \\
\hline $\mathrm{C}$ & $\stackrel{+}{+}$ & & \pm & + & + & + & + & + & $\stackrel{+}{+}$ & $=$ & $\stackrel{+}{+}$ & 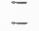 & $\stackrel{+}{+}$ & $\bar{t}$ \\
\hline B & + & + & + & - & + & + & + & + & - & + & - & - & - & - \\
\hline 13 & + & - & - & $1+$ & + & + & + & + & $=$ & - & - & - & - & + \\
\hline B & \pm & - & $\bar{I}$ & $1+$ & $\stackrel{+}{+}$ & + & + & + & \pm & $\overline{-}$ & + & $\bar{I}$ & \pm & \pm \\
\hline
\end{tabular}

I Yellow. 
TABLE II.-Complete characteristics of the different varieties of alkali-forming bacteria uhich survive pasteurization.

\begin{tabular}{|c|c|c|c|c|c|c|c|c|c|c|c|c|c|c|c|}
\hline \multirow[b]{2}{*}{ 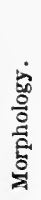 } & \multirow[b]{2}{*}{ 苞 } & \multirow{2}{*}{ 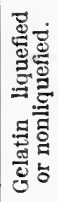 } & \multirow{2}{*}{ 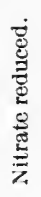 } & \multirow[b]{2}{*}{ 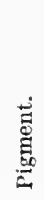 } & \multicolumn{10}{|c|}{ Acid production in - } & \multirow{2}{*}{ 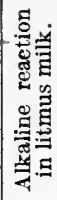 } \\
\hline & & & & & 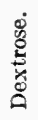 & 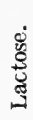 & 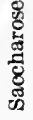 & 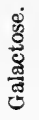 & 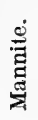 & 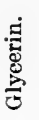 & 兽 & 咅 & 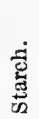 & 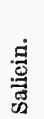 & \\
\hline $\mathrm{c}$ & + & - & - & - & - & - & - & - & - & - & - & - & - & - & + \\
\hline c & + & - & - & $1+$ & - & - & - & 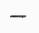 & - & - & - & 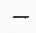 & - & - & + \\
\hline c & \pm & $=$ & \pm & $=$ & 二 & $=$ & $=$ & $=$ & $=$ & $=$ & $\bar{z}$ & - & $\bar{z}+(x+1)$ & $=$ & $\begin{array}{l}+ \\
+\end{array}$ \\
\hline $\mathrm{B}$ & \pm & - & $z$ & - & - & - & - & - & - & - & - & - & - & - & + \\
\hline $\mathrm{B}$ & $\begin{array}{llll}+ \\
+\end{array}$ & $\overline{-}$ & $\mp$ & \pm & $=$ & $=$ & $\overline{-}$ & $\overline{-}$ & $\bar{z}$ & $\overline{-}$ & $\bar{z}$ & $\bar{z}$ & $z$ & $=$ & $\stackrel{+}{+}$ \\
\hline
\end{tabular}

1 Yellow.

TABLE III.-Complete characteristics of the different varieties of the peptonizing bacteria which survive pasteurization.

\begin{tabular}{|c|c|c|c|c|c|c|c|c|c|c|c|c|c|c|c|}
\hline \multirow[b]{2}{*}{$\begin{array}{l}\overrightarrow{0} \\
\frac{0}{0} \\
\frac{0}{0} \\
\frac{0}{0} \\
\frac{1}{2}\end{array}$} & \multirow[b]{2}{*}{ 㤅 } & \multirow{2}{*}{ 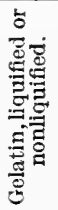 } & \multirow{2}{*}{ 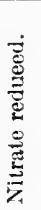 } & \multirow[b]{2}{*}{$\begin{array}{l}\vec{E} \\
\vec{E} \\
\vec{Z}\end{array}$} & \multicolumn{10}{|c|}{ Acid production in- } & \multirow{2}{*}{ 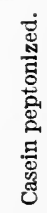 } \\
\hline & & & & & 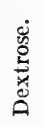 & 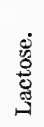 & 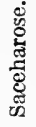 & 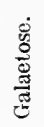 & 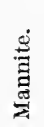 & 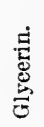 & 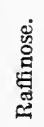 & 离 & $\begin{array}{l}\text { d. } \\
\text { t. } \\
\text { th }\end{array}$ & 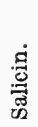 & \\
\hline $\mathrm{c}$ & $t$ & 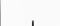 & 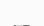 & $1+$ & + & t & + & - & - & - & - & & & 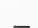 & \\
\hline $\mathrm{c}$ & $\begin{array}{l}+ \\
+\end{array}$ & $\stackrel{+}{+}$ & $=$ & ${ }^{2}+$ & \pm & + & + & $\vec{t}$ & $\bar{z}$ & $\vec{t}$ & $\bar{z}$ & $\overline{-}$ & $\bar{t}$ & $\overline{-}$ & \\
\hline $\mathrm{C}$ & + & + & - & - & + & + & + & + & - & - & - & - & - & - & \\
\hline C & $\stackrel{+}{+}$ & $\stackrel{+}{+}$ & $=$ & $\begin{array}{l}1+ \\
1+\end{array}$ & $\stackrel{+}{+}$ & $\begin{array}{l}+ \\
+\end{array}$ & $=$ & \pm & $=$ & $\overline{-}$ & $=$ & $\bar{z}+x+x+10$ & $=$ & $=$ & \\
\hline $\mathrm{c}$ & + & + & - & $1+$ & + & - & + & - & - & - & - & - & - & - & \\
\hline$\stackrel{\mathrm{C}}{\mathrm{C}}$ & $\stackrel{+}{+}$ & $\stackrel{+}{+}$ & $\begin{array}{llll}+ \\
+\end{array}$ & $1+$ & $\stackrel{+}{+}$ & $\stackrel{+}{+}$ & $\bar{z}$ & $\begin{array}{ll}+ \\
+\end{array}$ & $\begin{array}{llll}+ \\
+\end{array}$ & $=$ & $=$ & $=$ & $=$ & $=$ & \\
\hline C & + & + & + & - & + & + & - & + & - & - & - & - & - & + & \\
\hline - & + & + & $\stackrel{+}{+}$ & $\begin{array}{l}1+ \\
1+\end{array}$ & $\stackrel{+}{+}$ & $\begin{array}{l}+ \\
+\end{array}$ & $\mp$ & $\stackrel{+}{+}$ & こ & $\bar{z}+x+3+$ & $\bar{z}+x+x+3$ & $\Xi$ & 二 & $\bar{z}$ & \\
\hline $\mathrm{c}$ & + & + & + & $3+$ & + & + & + & + & + & \pm & 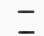 & $\bar{z}+x+x+x$ & $=$ & - & \\
\hline C & $\stackrel{+}{+}$ & + & $\stackrel{+}{+}$ & $1+$ & $\stackrel{+}{+}$ & $\begin{array}{l}+ \\
+\end{array}$ & \pm & $\begin{array}{l}+ \\
+ \\
+\end{array}$ & \pm & $\overline{-}$ & $\bar{z}+$ & 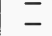 & $\overline{-}$ & $\bar{z}$ & \\
\hline $\mathrm{C}$ & + & + & + & $1+$ & + & - & + & + & - & + & - & - & + & + & \\
\hline$\stackrel{B}{B}$ & + & + & $=$ & $\overline{-}$ & $\stackrel{+}{+}$ & $\overline{-}$ & $\bar{t}$ & $\overline{+}$ & $\overrightarrow{+}$ & $\overline{+}$ & $\bar{z}$ & $=$ & $\bar{z}$ & $\begin{array}{l}+ \\
+\end{array}$ & \\
\hline B & + & + & + & $1+$ & + & - & + & + & - & + & + & - & + & + & \\
\hline B & + & + & + & - & + & + & + & + & + & + & - & - & + & + & \\
\hline${ }_{\mathrm{B}}^{\mathrm{B}}$ & $\stackrel{+}{+}$ & $\stackrel{+}{+}$ & $\stackrel{+}{+}$ & $\overline{-}$ & $\stackrel{+}{+}$ & $\bar{t}$ & $\mp$ & $\bar{t}$ & $\bar{z}$ & $\overline{+}$ & $\overline{-}$ & $\overline{-}$ & $\overline{+}$ & $\bar{t}$ & \\
\hline $\bar{B}$ & + & + & + & - & + & - & + & - & - & + & - & - & + & + & \\
\hline C & + & $\overline{-}$ & $\overline{-}$ & $\begin{array}{l}1+ \\
1+\end{array}$ & $\bar{t}$ & - & $\overline{-}$ & $=$ & $\bar{z}$ & $\bar{z}$ & $\bar{z}$ & - & - & $\bar{z}$ & $\stackrel{+}{+}$ \\
\hline $\mathrm{C}$ & + & $\overline{-}$ & $\bar{t}$ & 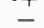 & + & $\bar{t}$ & $\overline{-}$ & + & $=$ & + & $=$ & - & $\bar{E}$ & $\overline{-}$ & + \\
\hline C & + & - & - & - & + & + & + & + & - & + & - & - & - & - & + \\
\hline $\begin{array}{l}\mathrm{C} \\
\mathrm{B}\end{array}$ & \pm & $\bar{z}$ & $\bar{z}$ & $\bar{z}$ & $\stackrel{+}{+}$ & \pm & \pm & \pm & $=$ & $\overline{-}$ & $\bar{z}$ & $\bar{z}$ & $\bar{z}$ & $\overline{-}$ & $\stackrel{+}{+}$ \\
\hline & + & - & - & $1+$ & + & + & - & - & - & - & - & - & + & - & + \\
\hline B & it & - & + & - & + & + & + & + & - & + & - & - & + & - & + \\
\hline C & $\stackrel{+}{+}$ & $\begin{array}{l}+ \\
+\end{array}$ & $\bar{z}$ & $1 \overline{7}$ & $\bar{t}$ & $\bar{z}$ & $\overline{-}$ & $\overline{-}$ & $\vec{z}$ & z & $\bar{z}$ & $\overline{-}$ & $\overline{-}$ & $\bar{z}$ & \\
\hline & + & + & + & $1+$ & + & - & - & - & - & - & - & - & - & - & \\
\hline $\mathrm{B}$ & + & + & - & - & - & - & - & - & $=$ & $\overline{-}$ & $\bar{z}$ & - & $\bar{z}$ & $=$ & \\
\hline $\mathbf{B}$ & \pm & + & + & $\overline{-}$ & $\overrightarrow{-}$ & - & $\overline{-}$ & $\overline{-}$ & - & - & - & - & - & - & \\
\hline B & + & + & - & - & + & - & - & - & - & - & - & - & - & - & \\
\hline
\end{tabular}




University of California

SOUTHERN REGIONAL LIBRARY FACILITY

305 De Neve Drive - Parking Lot 17 - Box 951388

LOS ANGELES, CALIFORNIA 90095-1388

Return this material to the library from which it was borrowed. 
Universi

South

Libr 